\title{
MONITORAMENTO DA CULTURA DO CRISÂNTEMO EM ESTUFA ATRAVÉS DO USO DE LISÍMETRO E ESTAÇÃO AGROMETEOROLÓGICA AUTOMATIZADOS
}

\author{
ANDRÉ LUÍS TEIXEIRA FERNANDES \\ Engenheiro Agrônomo
}

Orientador: Prof. Dr. MARCOS VINÍCIUS FOLEGATTI

Dissertação apresentada a Escola Superior de Agricultura "Luiz de Queiroz", da Universidade de São Paulo, para obtenção do título de Mestre em Agronomia, Área de Concentração: Irrigação e Drenagem.

PIRACICABA

Estado de São Paulo - Brasil

Julho / 1996 


\section{Dados Internacionais de Catalogação na Publicação (CIP) DIVISĀO DE BIBLIOTECA E DOCUMENTAÇĀO - Campuss “Luiz de Queiroz"/USP}

Fernandes, André Luís Teixeira

Monitoramento da cultura do crisântemo em estufa através do uso de lisimetro e estação agrometeorológica automatizados/André Luis Teixeira Fernandes. - - Piracicaba , 1996.

96p. : il.

Dissertação (mestrado) - - Escola Superior de Agricultura Luiz de Queiroz, 1996. Bibliografia.

1. Crisâmetro - Cultivo em estufa 2. Irrigação - Manejo 3. Lisimetro - Avaliação 4. Meteorologia agricola I. Título

CDD 635.93355

631.7

630.2515 


\section{MONITORAMENTO DA CULTURA DO CRISÂNTEMO EM ESTUFA ATRAVÉS DO USO DE LISÍMETRO E ESTAÇÃO AGROMETEOROLÓGICA AUTOMATIZADOS}

\section{ANDRÉ LUÍS TEIXEIRA FERNANDES}

Aprovada em: 09/09/1996

Comissão julgadora:

Prof. Dr. Marcos Vinícius Folegatti ESALQ/USP

Prof. Dr. Nilson Augusto Villa Nova ESALQ/USP

Prof. Dr. Edson Matsura

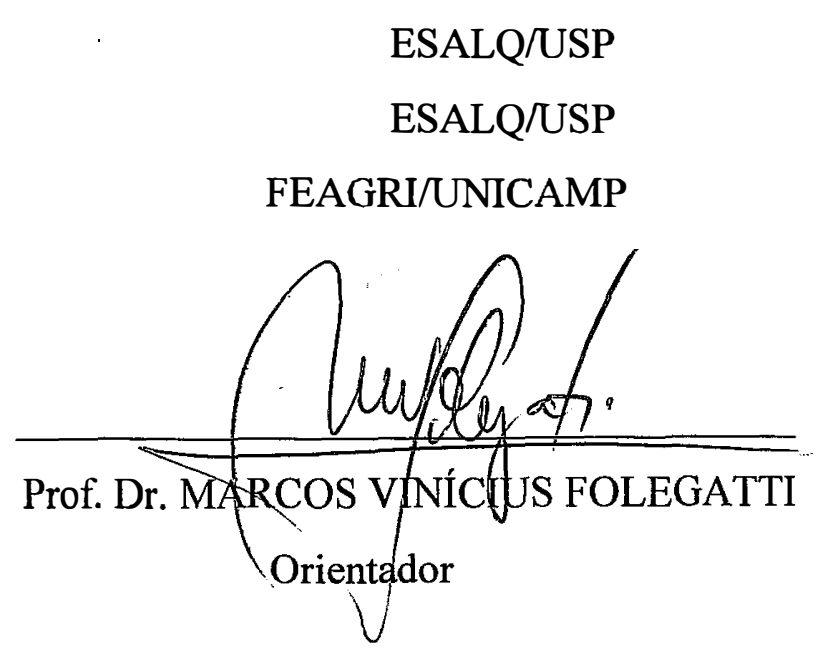


Aos meus pais, pelo estímulo, amizade, compreensão, paciência, orientação e amor, dedico este trabalho. 


\section{AGRADECIMENTOS}

Ao Prof. Marcos Vinícius Folegatti, pela orientação segura, pela confiança e apoio incondicionais.

Ao Prof. Antonio Roberto Pereira, pelas valiosas contribuições e idéias.

Ao pesquisador do Instituto Agronômico de Campinas, Marcelo Bento Paes de Camargo, pelas excelentes sugestões.

Ao aluno Alexandre Ferreira Develey, em seu trabalho de residência agronômica, pela inestimável contribuição em todo o processo de montagem do experimento e coleta de dados.

Aos meus colegas do curso de Mestrado, em especial a Marcos Scatolini, Selma, Raquel, Angelita, Virgílio, Fabiano, Paulo e Antonio Sérgio.

À CAPES, pela viabilização deste trabalho através da concessão de recursos.

Aos professores do Depto. de Engenharia Rural da Esalq, Tarlei Arriel Botrel, Rubens Duarte Coelho e José Antonio Frizzone, pela convivência e incentivo.

Aos funcionários do Depto. de Engenharia Rural, em especial José (Zezinho), Hélio e Gilmar, pela cooperação em todos os momentos.

Ás secretárias Sílvia, D. Vera e Roberta, pela eficiência.

À GHF, pelo fornecimento dos sensores de medida e "datalogger".

À Schoenmaker Van Zanten, pela concessão de suas instalações que permitiram os trabalhos de campo.

À Liliana, pelo apoio, incentivo, paciência e carinho.

À minha família.

À todos, que direta ou indiretamente, contribuíram para o sucesso deste trabalho. 
Não há limites para o homem que possui a cajacidade de sonhar e a determinaf̧ão de transformar em realidade o seu sonho. 
SUMÁRIO

LISTA DE TABELAS......................................................................... ix

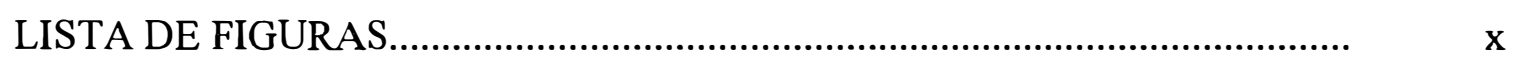

LISTA DE ABREVIATURAS E SÍMBOLOS................................................. xii

RESUMO_........................................................................................ xiv

SUMMARY ................................................................................. $\quad \mathrm{xvi}$

1. INTRODUÇÃO................................................................................. 1

2. REVISÃO DE LITERATURA............................................................. 3

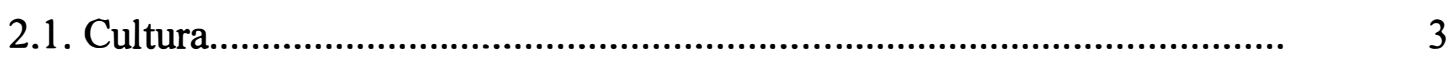

2.2. Manejo da irrigação.............................................................................. 3

2.3. Determinação da evapotranspiração.......................................................... 6

2.3.1. Evapotranspiração em estufas............................................................ $\quad 8$

2.3.2. Medidas de evapotranspiração......................................................... 9

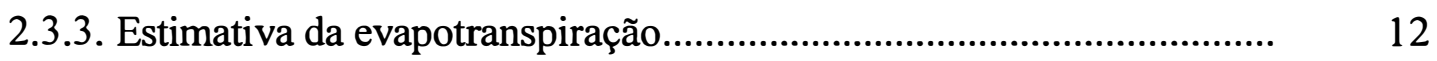

2.4. Radiação solar no interior de estufas...................................................... 16

2.5. Umidade do ar no interior de estufas...................................................... 18

2.6. Temperatura do ar no interior de estufas................................................. 18

2.7. Uso de estações automáticas para controle da irrigação.............................. 19

3. MATERIAL E MÉTODOS...................................................................... 23

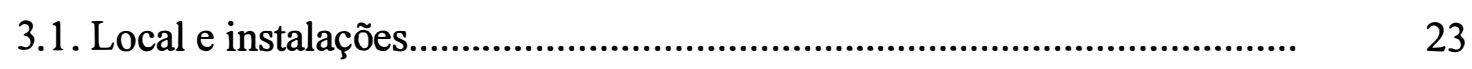

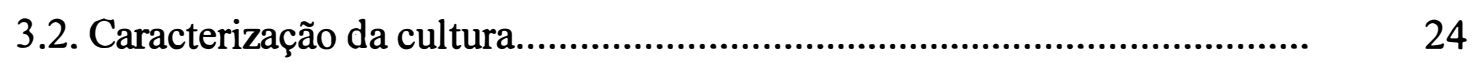

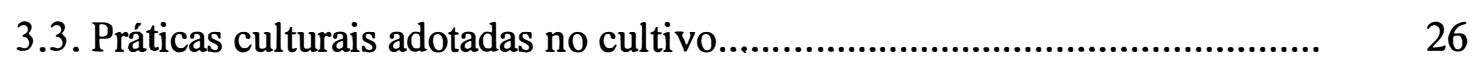

3.3.1 Controle fitossanitário................................................................. 27

3.3.2. Colheita das mudas......................................................................... 27

3.4. Sistema de irrigação..................................................................... 28

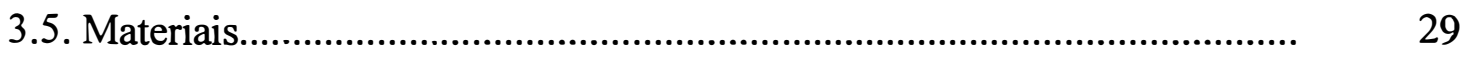

3.5.1. Evapotranspiração da cultura (ETc medida)........................................ 29

3.5.2. Obtenção dos dados meteorológicos.................................................. 32

3.5.3. Outros equipamentos instalados no interior da estufa........................... 34

3.5.3.2. Tanque evaporimétrico................................................................ 34 
3.5.3.2. Tensiômetros..................................................................................

3.5.3.3. Evaporímetro de Piche............................................................... 36

3.6. Metodologia................................................................................... 36

3.6.1. Avaliação do sistema de irrigação........................................................ 36

3.6.2. Análise física do solo........................................................................ 38

3.6.3. Determinação do índice de área foliar................................................. 42

3.6.4. Métodos de estimativa da Evapotranspiração potencial (ETp).............. 43

3.6.4.1. Método do tanque evaporimétrico..................................................... 43

3.6.4.2. Método de Camargo....................................................................

3.6.4.3. Método de Makkink.......................................................................

3.6.4.4. Método da Radiação Solar........................................................... 45

3.6.4.5. Método de Jensen-Haise................................................................. 46

3.6.4.6. Método de Linacre........................................................................ 47

3.6.4.7. Método de Hargreaves-Samani........................................................ 47

3.6.4.8. Método de Penman.......................................................................... 47

3.6.4.9. Método de Penman-piche................................................................ 49

3.6.5. Método de estimativa da Evapotranspiração da Cutura......................... 49

3.6.5.1. Método de Penman-Monteith....................................................... 49

4. RESULTADOS E DISCUSSÃO ………………..................................... 51

4.1. Variação dos elementos meteorológicos internos e externos à estufa........... 51

4.1.1. Radiação solar global..................................................................... 51

4.1.2. Velocidade do vento........................................................................ 58

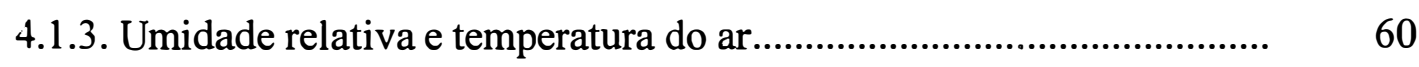

4.2. Estimativa da evapotranspiração da cultura dentro da estufa plástica.......... 65

4.3. Comparação da Evapotranspiração interna e externa.................................. $\quad 74$

4.4. Comparação do manejo da irrigação através do lisímetro e manejo

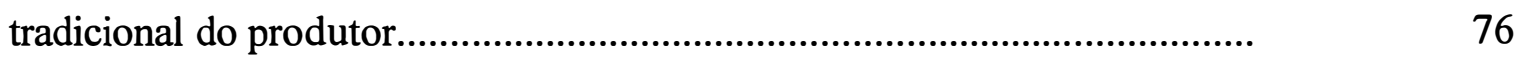

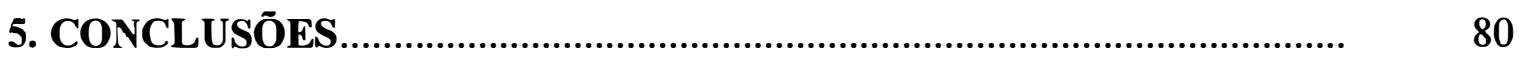

REFERÊNCIAS BIBLIOGRÁFICAS.......................................................... 82

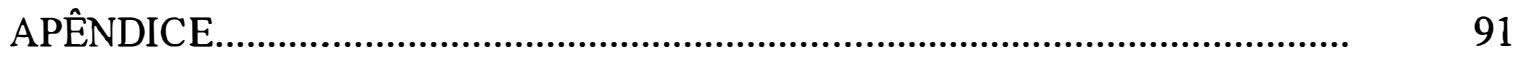




\section{LISTA DE TABELAS}

Tabela

Página

1 Adubos utilizados e suas concentrações no tanque de fertirrigação.............

2 Teste de uniformidade de aplicação da lâmina de irrigação para os

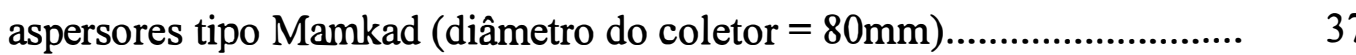

3 Teste de uniformidade de aplicação de lâmina no 38 gotejamento

$4 \quad$ Análise granulométrica média no solo........................................................ 39

$5 \quad$ Condutividade elétrica e densidade global do solo...................................... 39

$6 \quad$ Testes de infiltração de água no solo.......................................................... 40

7 Valores de coeficientes de Tanque (Kp), com base nas condições diárias de vento e umidade relativa do ar, para tanque classe $\mathrm{A}$ instalado em área vegetada com grama ou em lavouras de baixo porte

8 Radiação extraterrestre (Q) em milímetros de evaporação equivalente no dia 15 de cada mês...................................................................................

9 Elementos climáticos monitorados no interior da estufa.............................. 52

10 Continuação dos elementos climáticos internos............................................ 53

11 Elementos climáticos monitorados no exterior da estufa............................ 54

12 Continuação dos elementos climáticos externos.......................................... 55

13 Parâmetros meteorológicos internos e externos (dia 27/10/96)................... 61

14 Comparação UR int. $x$ UR ext................................................................. 92

15 Obtenção do coeficiente de cultura $(\mathrm{Kc})$ a partir dos valores de índice de área foliar (IAF) ..................................................................................... 93

16 Comparação dos dados estimados X dados observados................................ 68

17 Valores estimados de evapotranspiração da cultura (ETc)......................... 94

18 Continuação dos valores estimados da evapotranspiração da cultura......... 95 


\section{LISTA DE FIGURAS}

Figura

Pagina

1 Esquema de aquisição de dados através de estações automáticas.................. 22

2 Dimensão total da estufa....................................................................... 24

3 Corte transversal do lisímetro................................................................ 31

4 Detalhe da estrutura de sustentação do lisímetro........................................... 31

$5 \quad$ Calibração do lisímetro............................................................................ 32

6 Disposição dos sensores no interior e fora da estufa....................................... 33

7 Disposição dos sensores no canteiro no interior da estufa............................. 34

$8 \quad$ Potencial da água no solo, em atm.......................................................... 35

9 Curva de retenção da água no solo................................................................. 39

10 Teste (1) de infiltração de água no solo..................................................... 41

11 Teste (2) de infiltração de água no solo....................................................... 41

12 Índice de área foliar $x$ dias após o plantio................................................... 42

13 Valores diários de radiação solar global obtidos no interior e fora da

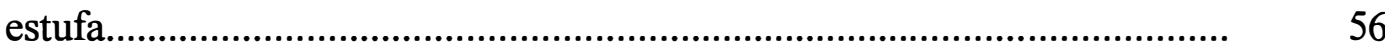

14 Análise dos valores de radiação solar global no interior e fora da estufa....... 56

15 Radiação solar global no dia 29/11/95 (céu limpo)....................................... 57

16 Radiação solar global no dia 28/10/95 (dia nublado)..................................... 58

17 Velocidade do vento $(\mathrm{m} / \mathrm{s})$, medida no exterior da estufa............................. 59

18 Velocidade máxima do vento fora da estufa................................................ 59

19 Dados de temperatura, radiação e umidade relativa.......................................... 61

20 Dados médios de UR\% no interior e externamente à estufa.......................... 62

21 Comparação UR int. e ext. (dia 11/10/05)..................................................... 63

22 Temperatura média no interior da estufa................................................... 64

23 Regressão linear T(méd) interna e externa ................................................. 64

24 Temperatura máxima no interior da estufa.................................................. 64

25 Regressão linear $\mathrm{T}(\max )$ interna e externa................................................... 64

26 Temperatura mínima no interior da estufa................................................... 64

27 Regressão linear $\mathrm{T}(\mathrm{min})$ interna e externa................................................... 64 
28 Determinação do IAF a partir de regressão linear........................................... 66

29 Comparações dos diferentes métodos de estimativa com o lisímetro

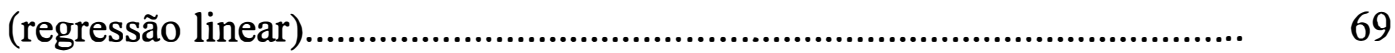

30 Continuação das comparações dos diferentes métodos de estimativa com o

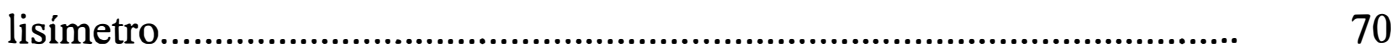

31 Determinação dos coeficientes a e b de Makkink......................................... 71

32 Comparação ETlisímetro x ETtanque evaporimétrico..................................... 73

33 Comparação ET interna e externa (Camargo).............................................. 75

34 Comparação ET interna e externa (Penman)................................................ 75

35 Resumos semanais das irrigações e evapotranspirações medidos através do lisímetro com o manejo da irrigação a critério da empresa............................. 77

36 Resumos semanais das irrigações e da evapotranspiração nas semanas onde foi feito o manejo através dos dados do lisímetro de célula de carga. $\quad 78$ 


\section{LISTA DE SIGLAS, ABREVIATURAS E SÍMBOLOS}

ETp $=$ evapotranspiração potencial, mm.dia ${ }^{-1}$

$\mathrm{ETo}=$ evapotranspiração de referência para grama, $\mathrm{mm} \cdot \mathrm{dia}^{-1}$

ETa $=$ evapotranspiração de referência para alfafa, mm.dia ${ }^{-1}$

$\mathrm{ETr}=$ evapotranspiração real, $\mathrm{mm} \cdot \mathrm{dia}^{-1}$

$\mathrm{ETm}=$ evapotranspiração máxima, $\mathrm{mm} \cdot \mathrm{dia}^{-1}$

ETc $=$ evapotranspiração da cultura, mm.dia ${ }^{-1}$

ETca $=$ evapotranspiração potencial, método do Tanque, $\mathrm{mm} \cdot \mathrm{dia}^{-1}$

ETcam = evapotranspiração potencial, método de Camargo, mm.dia ${ }^{-1}$

ETmak = evapotranspiração potencial método de Makkink, mm.dia ${ }^{-1}$

ETrad =evapotranspiração potencial, método da Radiação Solar, mm.dia ${ }^{-1}$

ETjh $=$ evapotranspiração potencial, método de Jensen \& Haise, mm.dia ${ }^{-1}$

ETlin = evapotranspiração potencial, método de Linacre, $\mathrm{mm}_{\mathrm{dia}}{ }^{-1}$

ETh\&sam = evapotranspiração potencial, método de Hargreaves \& Samani, mm.dia ${ }^{-1}$

ETpen $=$ evapotranspiração potencial, método de Penman, $m$ m.dia $^{-1}$

ETps = evapotranspiração potencial, método de Penman simplificado, mm.dia ${ }^{-1}$

ETpm = evapotranspiração da cultura , método de Penman-Monteith, mm.dia ${ }^{-1}$

CUC $=$ coeficiente de uniformidade de Christiansen, $\%$

VIB = velocidade de infiltração básica do solo, $\mathrm{mm} \cdot \mathrm{h}^{-1}$

$\mathrm{Kp}=$ coeficiente de tanque

$\mathrm{Kc}=$ coeficiente da cultura

$\mathrm{ECA}=$ evaporação do tanque, mm.dia ${ }^{-1}$

Qo $=$ radiação solar extraterrestre, $\mathrm{mm} \cdot \mathrm{dia}^{-1}$

$\mathrm{Rs}=$ radiação solar ao nível da superfície, $\mathrm{mm} \cdot \mathrm{dia}^{-1}$

$\mathrm{Rn}=$ radiação solar líquida, $\mathrm{mm} \cdot \mathrm{dia}^{-1}$

$\mathrm{Rd}=$ radiação solar difusa, $\mathrm{mm} \cdot \mathrm{dia}^{-1}$

$\mathrm{T}=$ temperatura média do período, ${ }^{\circ} \mathrm{C}$

Tmáx $=$ temperatura máxima do período, ${ }^{\circ} \mathrm{C}$

Tmín $=$ temperatura mínima do período, ${ }^{\circ} \mathrm{C}$ 
To $=$ temperatura do ponto do orvalho, ${ }^{\circ} \mathrm{C}$

$\mathrm{F}=$ fator de ajuste da temperatura da equação de Camargo

$\mathrm{W}=$ fator de ponderação da temperatura de bulbo úmido e da constante psicrométrica

$\mathrm{c}=$ parâmetro da equação do método da Radiação Solar

$\mathrm{h}=$ altitude local, $\mathrm{m}$

$\mathrm{e}_{\mathrm{a}}=$ pressão atual de vapor, $\mathrm{kPa}$

$\mathrm{e}_{\mathrm{s}}=$ pressão de saturação de vapor, $\mathrm{kPa}$

$A=$ constante da equação da pressão de saturação de vapor $(A=6,10 \mathrm{mb}=4,58 \mathrm{mmHg}=0,61 \mathrm{kPa}$,

para cálculo de $\mathrm{e}_{\mathrm{s}} \mathrm{em} \mathrm{mb}, \mathrm{mmHg}$ e $\mathrm{kPa}$, respectivamente)

$\mathrm{Ea}=$ demanda atmosférica, $\mathrm{mm} \cdot \mathrm{dia}^{-1}$

$\mathrm{Ud}=$ velocidade do vento, $\mathrm{m} \cdot \mathrm{s}^{-1}$

$\mathrm{UR}=$ umidade relativa do ar, \%

$\mathrm{Pi}=$ evaporação de Piche, $\mathrm{mm}$

$\mathrm{IAF}=$ índice de área foliar, $\mathrm{m}^{2}$ de folha. $\mathrm{m}^{-2}$ terreno

$r_{c}=$ resistência do dossel, s.m ${ }^{-1}$

$r_{a}=$ resistência aerodinâmica, s.m $^{-1}$

$\Theta=$ latitude local, graus

$\gamma=$ constante psicrométrica, $\mathrm{kPa} .{ }^{\circ} \mathrm{C}^{-1}$

$\Delta=$ taxa de variação de tensão de saturação de vapor com a temperatura, $\mathrm{kPa} \cdot{ }^{\circ} \mathrm{C}^{-1}$

$\sigma=$ constante de Stefan - Boltzman, mm.dia ${ }^{-1} \cdot T^{-4}$

$\rho=$ poder refletor da superfície (albedo) 


\title{
MONITORAMENTO DA CULTURA DO CRISÂNTEMO EM ESTUFA ATRAVÉS DO USO DE LISÍMETRO E ESTAÇÃO AGROMETEOROLÓGICA AUTOMATIZADOS
}

\author{
Autor: André Luís Teixeira Fernandes \\ Orientador: Prof.Dr. Marcos Vinícius Folegatti
}

\section{RESUMO}

Com o objetivo de estudar métodos de controle de irrigação numa cultura de crisântemo, instalou-se uma estação agrometeorológica automática, numa estufa de $5.600 \mathrm{~m}^{2}$, com os seguintes sensores, conectados a um coletor de dados: temperatura do ar, umidade relativa do ar, radiação solar global e lisímetro de pesagem com célula de carga.

Para efeito de comparação, também forạm instalados sensores fora da estufa: velocidade e direção do vento, umidade relativa do ar, temperatura do ar e radiação solar global.

Dentro da estufa, foram obtidos valores sempre menores de radiação solar, devido à perda de transmissividade decorrente do plástico, que assumiu valores médios em torno de $30 \%$.

A umidade relativa do ar teve comportamento contrário ao da temperatura, ou seja, valores elevados no período noturno e baixos durante o diurno. Os valores de temperatura média, máxima e mínima foram sempre maiores dentro da estufa plástica.

A partir dos dados meteorológicos obtidos, estimou-se a evapotranspiração da cultura utilizando-se os seguintes métodos: Tanque evaporimétrico, Camargo, Makkink, Radiação solar, Jensen-Haise, Linacre, Hargreaves-Samani, Penman, Penman-piche e Penman-Monteith. Os resultados foram comparados com as medições do lisímetro, considerado padrão, sendo que os métodos que obtiveram maiores índices de correlação foram: Jensen-Haise (76,89\%); Radiação Solar (75,77\%); Makkink (75,50\%) e Penman (73,12\%). 
Foi também comparado o manejo de irrigação adotado pela empresa com o manejo realizado a partir de leituras do lisímetro de pesagem. Com o manejo realizado através das pesagens, o solo foi mantido em níveis mais baixos de umidade, sendo as irrigações menos frequentes. Nessa condição, não foram verificadas diferenças de produção de estacas de crisântemo, no que diz respeito ao número e qualidade das hastes colhidas. 


\title{
USE OF AN AUTOMATIC WEATHER STATION AND A WEIGHING LYSIMETER TO IRRIGATION SCHEDULING OF A CRISANTHEMUM CROP
}

\author{
Autor: André Luís Teixeira Fernandes \\ Orientador: Prof.Dr. Marcos Vinícius Folegatti
}

\section{SUMMARY}

In order to study some methods to schedule the irrigation of crysanthemun crop, it was installed an automatic weather station inside a greenhouse that is $5600 \mathrm{~m}^{2}$, with the following sensors connected to datalogger: air temperature, relative humidity, solar radiation and a weighing lysimeter.

Also it was installed some sensor outside a greenhouse, in order to compare the inside with the outside data: air temperature, relative humidity, solar radiation, wind speed and wind direction.

Inside a greenhouse, it was always obtained lower values of solar radiation, because of the loss by transmissibility of the plastic, that reachead values about $30 \%$.

The medium, maximum and minimum temperature data were always higher inside the greenhouse than outside.

Evapotranspiration (ET) was estimated using the weather station data by the following methods: Solar Radiation, Pan Evaporation, Camargo, Makkink, Jensen-Haise, Linacre, Hargreaves-Samani, Penman, Penman-piche and Penman-Monteith. The results were compared with the weighing lysimeter data as a standard. The best correlation index were obtained by: Jensen-Haise (76,89\%); Solar Radiation (75,77\%); Makkink $(75,50)$ and Penman $(73,12 \%)$. 
The managment using lysimeter data, the soil was mantained at lower levels and the the irrigations were less frequent. The practice of keep the soil with less levels of humidity did not reduce the stake production, neither number nor quality from the rods. 


\section{1 . INTRODUÇÃO}

A irrigação constitui-se numa técnica que tem por finalidade fornecer água às culturas, de forma a reduzir os riscos na produção agrícola. A eficiência de um sistema de irrigação está intimamente ligada ao seu manejo, que deve considerar aspectos econômicos, sociais e ecológicos.

$\mathrm{O}$ manejo deficiente e a falta de drenagem tem sido as principais causas do baixo desempenho da maioria dos projetos de irrigação no Brasil.

Essa situação se agrava ainda mais quando o sistema de produção é conduzido dentro de ambientes protegidos, como casas de vegetação ou estufas. Nestes casos, a irrigação tem uma importância ainda maior, por se tratar da única forma de fornecimento de água, além do fato da grande parte da aplicação dos fertilizantes ser realizada via água de irrigação.

Existem vários métodos dos quais o irrigante pode dispor para programar a irrigação, podendo ser classificados em: a) métodos baseados no solo; b) métodos baseados na planta; c) métodos baseados no balanço de água no solo; d) evaporímetros e e) informações meteorológicas.

Devido às dificuldades operacionais de obtenção de dados meteorológicos em estações convencionais, os métodos de manejo de irrigação baseados em informações meteorológicas não têm sido utilizados em grande escala. 
Entretanto, com surgimento de sistemas e armazenadores de dados (dataloggers) e sensores precisos com um custo acessível e com possibilidade de processar os dados em tempo real, o emprego de estações meteorológicas automáticas para o controle da irrigação torna-se bastante promissor.

A viabilidade do uso de informações meteorológicas para estimar a evapotranspiração do crisântemo foi estudada mediante comparações com as medidas de evapotranspiração da cultura, obtidas através de um lisímetro de pesagem com célula de carga, instalado na área experimental.

Esse trabalho teve como objetivo avaliar o uso de uma estação agrometeorológica automática e de um lisímetro de pesagem para o monitoramento da irrigação de uma cultura de crisântemo em estufa e comparar com o manejo de irrigação tradicional utilizado pelos produtores. 


\section{REVISÃo BIBLIOGRÁFICA}

\subsection{Cultura}

O gênero crisântemo é originário do Japão, tendo sido introduzido no Ocidente há cerca de 200 anos. É largamente cultivada no Brasil, sendo que o cultivo em vaso ocupa o primeiro lugar no mercado, respondendo por aproximadamente $80 \%$ do total. Com relação ao cultivo chamado "de corte", ocupa o segundo lugar, perdendo apenas para a rosa.

Segundo Barbosa \& Martinez (1995), os motivos para a grande aceitação do crisântemo no mercado são os seguintes: grande diversidade de variedades, com inúmeras colorações e formas de inflorescências; diferentes portes de plantas; durabilidade da flor cortada (em torno de 15 dias) e da planta em vaso (cerca de 30 dias); precisão com que essa espécie responde à indução floral pelo controle fotoperiódico, permitindo um planejamento exato de produção e de comercialização.

\subsection{Manejo da irrigação}

Segundo Burman (1983), o principal objetivo da irrigação é fornecer às plantas água suficiente para prevenir estresse que pode causar redução na produção ou baixa 
qualidade do produto colhido. O tempo de irrigação requerido e a quantidade de água a ser aplicada são governados pelas condições climáticas prevalecentes, pela cultura (estágio de crescimento), pela capacidade de retenção da água no solo e pela extensão do sistema radicular.

Esse mesmo autor afirma que a necessidade de irrigação pode ser determinada por vários métodos, entre eles: observação da cultura; estresse hídrico da planta; balanço de água no solo; potencial da água no solo ou na planta; medidas diretas (lisímetros) e informações climatológicas, que são utilizadas para estimar o consumo de água das culturas.

Stegman et al. (1983) observam que apesar dos métodos de manejo disponíveis, os irrigantes não apresentam grande receptividade a qualquer método em particular. Os fatores que podem contribuir para esse fato são: a) o custo da água de irrigação, que é frequentemente baixo em relação aos custos das práticas de manejo; b) a redução da produtividade, causada por irrigações tardias, fertilização inadequada e irrigação excessiva, não é facilmente visualizada; c) os dados necessários à tomada de decisão nem sempre são disponíveis; d) as decisões são tomadas por pessoas que visam apenas o aspecto econômico, que possuem pouco ou nenhum conhecimento, ou qualquer treinamento em manejo de um sistema tão complexo com $\cos ^{\dagger}$ sistema solo-plantaatmosfera.

Segundo Martin et al. (1990) e Hill (1991), primeiramente deve-se definir os objetivos do manejo da irrigação para depois escolher a estratégia adequada de controle de irrigação. Maximizar o lucro é um objetivo comum, embora existam outros, como: minimizar os custos de irrigação, otimizar a distribuição quando o suprimento de água é limitado, minimizar a poluição ou otimizar a produção de um sistema de capacidade limitada. A disponibilidade de água e os custos de irrigação, segundo esse autor, são usualmente os fatores mais críticos na determinação dos objetivos do manejo.

Scaloppi (1985) afirma que o consumo de energia na agricultura irrigada é alto, sendo que o principal desafio é desenvolver técnicas e métodos de engenharia para 
efetivarem as práticas para economizar energia, incluindo o dimensionamento, a operação e o manejo dos sistemas de irrigação. Segundo o autor, para melhor atender às decisões econômicas em função do crescente custo da energia, há necessidade de maiores informações sobre as relações da energia na irrigação.

Hill (1991) define alguns procedimentos para viabilizar um manejo adequado da irrigação de determinada cultura: a) avaliar o sistema de irrigação (determinar lâmina média de aplicação, eficiência e capacidade de operação); b) selecionar um método de controle da irrigação adequado; c) monitorar a performance da cultura em intervalos durante a estação de crescimento; d) realizar avaliações depois da estação de crescimento, e determinar mudanças para o próximo ano.

O controle da irrigação, segundo Dourado Neto et al. (1991), é uma técnica que será realmente valorizada quando os recursos hídricos se tornarem escassos, o que já ocorre em algumas regiões do País.

Esse autor também observa que, para a maioria dos sistemas de irrigação, a base do controle é a armazenagem de água no solo, e não o estresse de água na planta, citando os seguintes fatores básicos para tomada de decisão de uma irrigação: a) determinar o valor atual e prever a disponibilidade de água do solo para um período após a última irrigação; b) estimar possíveis atrasos na data da irrigação e meios de se evitar o efeito adverso do estresse de água na planta; c) quantificar o volume de água aplicado de forma a se obter elevadas eficiências de irrigação; d) avaliar as consequências de se irrigar fora do momento exato ou de se aplicar volumes que provoquem excesso ou déficit de água na cultura.

Segundo Hill (1991), normalmente, os métodos de irrigação incluem alguns dos seguintes procedimentos: a) calcular o armazenamento de água no solo utilizando informações de solo, culturas, tempo e manejo de irrigação; b) monitorar o conteúdo de água no solo com instrumentos ou técnicas amostrais, como tato, gravimetria, blocos de gesso, tensiômetros e sonda de nêutrons; c) observar e medir indicadores de plantas, como quando a cultura mostra evidências de estresse por mudança de cor ou murcha da 
folha, ou pelo uso de medidas de temperatura do dossel; d) a combinação dos métodos acima, a fim de se reduzirem as visitas ao campo.

\subsection{Determinação da Evapotranspiração}

Segundo Pereira (1994), evaporação é o fenômeno pelo qual uma substância passa da fase líquida para a fase gasosa. É um fenômeno que exige o suprimento de energia externa sendo, portanto, um processo de transformação de calor sensível em calor latente. Transpiração é a evaporação da água que foi utilizada nos diversos processos metabólicos necessários ao crescimento e desenvolvimento das plantas.

Numa superfície vegetada, ocorrem simultaneamente os processos de evaporação e de transpiração, sendo que o fenômeno global pode ser chamado de evapotranspiração.

A evapotranspiração, segundo Alfonsi et al. (1990), pode ser classificada em:

- Evapotranspiração potencial (ETp): corresponde à água utilizada por uma extensa superficie vegetada, em crescimento ativo e cobrindo totalmente o terreno, estando este bem suprido de umidade;

- Evapotranspiração de referência para grama (ETo): evapotranspiração que ocorre em uma extensa superfície de grama, com porte de 8 a $15 \mathrm{~cm}$, em crescimento ativo, cobrindo totalmente o solo e sem restrição de água.

- Evapotranspiração de referência para alfafa (ETa): evapotranspiração que se verifica em uma cultura de alfafa, com 30 a $50 \mathrm{~cm}$ de altura, e bordadura mínima de $100 \mathrm{~m}$, cultivada sem deficiência hídrica.

Embora se reconheça que a alfafa possua características aerodinâmicas mais representativas da maioria das culturas agronômicas do que a grama, esta última é mais utilizada pelo simples fato de a grande maioria das estações agrometeorológicas serem gramadas, e também por ser mais facilmente adaptada à diferentes condições climáticas. 
Doorembos \& Pruitt (1977) introduziram o conceito de Evapotranspiração da cultura (ETc), caracterizando-se por ser a evapotranspiração de uma cultura agronômica, livre de doenças, desenvolvendo-se em uma área cultivada de um ou mais hectares, sob condições otimizadas de solo, incluindo água e fertilidade.

O conhecimento da ETc é de fundamental importância para o manejo da irrigação de uma cultura, pois representa a água que deve ser reposta ao solo para manter o crescimento e a produção em condições ideais.

Segundo Smith (1991), um dos procedimentos mais utilizados na estimativa das necessidades de água dos cultivos envolve um processo que se desenrola em duas etapas. $\mathrm{Na}$ primeira, uma equação empírica ou semi-empírica é utilizada para estimar a Evapotranspiração de referência (ETo); na segunda, a Evapotranspiração da cultura é obtida pela multiplicação da ETo por um coeficiente de cultura $(\mathrm{Kc})$ empírico.

Um procedimento mais eficaz estaria em conduzir o processo de estimativa da Evapotranspiração em uma só etapa, descartando-se a utilização dos coeficientes de cultura. Para isso, sugere que o método de Penman-Monteith seja adotado como padrão, com a utilização de valores adequados de resistência aerodinâmica e de resistência do dossel, específicas para cada cultura. Entretanto, a adoção imediata desse método incorreria em algumas dificuldades na obtenção de valores confiáveis para a resistência do dossel.

Pereira (1994) cita vários fatores que podem interferir na evapotranspiração das culturas, entre eles: a abertura dos estômatos, a reflectância, a rugosidade aerodinâmica, a extensão da área coberta pelo vegetal ,a estação do ano, a disponibilidade de energia, a demanda atmosférica e o suprimento de água do solo às plantas.

Outros fatores que podem influenciar nas taxas de evapotranspiração são as condições do solo, os fertilizantes, as infestações de pragas e doenças, as práticas agrícolas e a irrigação (Doorembos \& Pruitt, 1977).

A altitude também afeta diretamente as temperaturas do solo e do ar, e a pressão atmosférica, que são fatores que também influenciam a evapotranspiração. Para um dado 
local, a disponibilidade de radiação é controlada pelo poder refletor da superfície, que é expresso pelo coeficiente de reflexão (albedo). Superfícies mais claras refletem mais que as escuras, e portanto, têm menos energia disponível. No caso de estufas, por exemplo, o albedo assume um valor maior que em cultivos em campo, devido à cobertura com plástico transparente. A demanda atmosférica é controlada pelo poder evaporante do ar. Quanto mais seco estiver o ar, maior será a demanda atmosférica. No entanto, existe inter-relação entre a demanda pelo ar e o suprimento de água pelo solo (Pereira, 1994).

\subsubsection{Evapotranspiração em estufas}

Quando se cultiva em estufa, deve-se estar atento às diferenças no ambiente quando se compara com o cultivo em campo, no que diz respeito à temperatura, umidade relativa, radiação solar e, consequentemente, a evapotranspiração.

A cobertura plástica da estufa altera o balanço de radiação e o balanço energético, com relação ao exterior. Em consequência, altera também a evapotranspiração (Farias et al., 1994).

No interior de estufas, em geral, a evapotranspiração é menor que a verificada externamente, o que atribui-se, basicamente, à parcial opacidade da cobertura plástica à radiação solar e também à reduzida ação dos ventos, que se constituem nos principais fatores da demanda evaporativa da atmosfera. A diferença entre a evapotranspiração interna e externa varia de acordo com as condições meteorológicas; em geral, a ET no interior da estufa fica em torno de 60 a $80 \%$ da verificada no exterior (Montero et al., 1985 ; Rosenberg et al., 1989 e Farias et al., 1994).

As coberturas plásticas criam condições bastante diferentes daquelas encontradas a céu aberto e são impermeáveis aos líquidos, impedindo a entrada da água da chuva, tornando-se extremamente importante um melhor conhecimento das exigências hídricas 
das plantas no interior de estufas, devido ao fato de a irrigação ser a única forma de suprimento de água às culturas (Farias et al., 1994).

\subsubsection{Medidas de Evapotranspiração}

A medida direta da evapotranspiração é extremamente difícil e onerosa. Difícil porque exige instalações e equipamentos especiais; e onerosa porque tais estruturas são de alto custo, justificando-se apenas em condições de pesquisa (Pereira, 1994).

$\mathrm{O}$ método direto mais comumente utilizado é o lisímetro, que devido à sua alta precisão, é utilizado como padrão de comparação para outros métodos.

Lisímetros são estruturas construídas com diferentes tipos de materiais e têm a função de representar uma condição específica de campo. Podem apresentar uma superficie nua ou coberta por vegetação, sendo utilizados para determinar evaporação do solo nú, desenvolvimento de culturas e evapotranspiração (Aboukhaled et al., 1982).

O lisímetro está separado do solo contíguo, porém sua superfície é indistinguível do solo circunvizinho. Existem vários tipos de lisímetros, sendo que o tamanho e a forma de cada um é baseado no requerimento específico do estudo e das condições de construção e custos envolvidos.

Gangopadhyaya et al. (1966) estabeleceram os principais cuidados na instalação dos lisímetros: a) o lisímetro deve ser suficientemente grande para assegurar a sua representatividade no que diz respeito a cobertura vegetal e efeito de sua presença; b) as condições físicas no interior do equipamento devem ser as mesmas da área vizinha; c) devem ser instalados em locais onde o efeito da advecção seja minimizada.

Hoje em dia, porém, os pesquisadores procuram trabalhar com superfícies descontínuas, justamente para estudar os efeitos da advecção.

Um tipo de lisímetro foi proposto por Thornthwaite, denominado evapotranspirômetro. Consiste de um tanque de $4 \mathrm{~m}^{2}$,com $70 \mathrm{~cm}$ de profundidade, 
dotado de dispositivos de suprimento e percolação de água com o nível de água mantido constante por meio de um sistema de válvula e bóia. Gangopadhyaya et al (1966) \& Marques (1972) relataram e discutiram as sucessivas modificações introduzidas no modelo original de Thornthwaite. O evapotranspirômetro, basicamente, é um instrumento para medida da evapotranspiração potencial (Gangopadhyaya et al. 1966), embora seja também utilizado em estudos de evaporação do solo (Marques, 1972).

Camargo (1966), em três localidades do estado de São Paulo, comparou evapotranspiração medida em um tipo de evapotranspirômetro de Thornthwaite modificado e estimada segundo as fórmulas de Thornthwaite, Penman-Bavel, Blaney e Criddle adaptada para as suas condições, encontrando boas correlações entre os valores medidos e estimados.

Segundo Howell et al. (1985), lisímetros de pesagem são os mais utilizados em pesquisas para mensurar de forma direta a evapotranspiração em períodos menores do que um dia. Outros métodos como a razão de Bowen e o método de correlação dos turbilhões apresentam bons resultados na mensuração da evapotranspiração a curto prazo. Embora os lisímetros de pesagem estejam sendo usados extensivamente, a mais de vinte e cinco anos nos Estados Unidos e em outros países, o desenho estrutural destes apresenta-se o mais variado possível. A variabilidade do "design" está relacionada com os objetivos da pesquisa e melhorias e refinamentos dos sistemas de pesagem. Harrold (1966) e Tanner (1967) realizaram uma extensa revisão sobre o desenvolvimento dos lisímetros e elaboraram as limitações a serem consideradas no dimensionamento de cada um deles.

- A sensibilidade da evapotranspiração medida em lisímetros de pesagem está diretamente relacionada com o período de tempo no qual será feita a integração da evapotranspiração. Medidas de evapotranspiração com intervalos de integração menores do que 10-15 min são geralmente impraticáveis. Muitos lisímetros têm precisões de 0,01 $\mathrm{mm}$. Contudo, a interferência do vento limita essa sensibilidade em cerca de $0,02 \mathrm{~mm}$ (Ritchie \& Burnett, 1968). A precisão para um intervalo de integração diário (24 h) é de 
$0.1 \mathrm{~mm}$. A sensibilidade desejada para o lisímetro pode ser obtida contrabalançando o peso "morto", ou seja, o peso do dispositivo e o solo seco, mensurando o peso "vivo", a água contida no solo com escalas de sensibilidade. Podendo aumentar a área da superfície para uma profundidade média (Black et al. 1968; Pruitt \& Angus, 1960).

A profundidade de cada lisímetro está relacionada com a sensibilidade desejada (Pruitt \& Angus, 1960). Muitos lisímetos apresentam profundidades que excedem 1,6 m, embora a maioria das culturas retirem água do solo a uma profundidade inferior a $1,5 \mathrm{~m}$. Em pesquisas com evapotranspiração, a profundidade do lisímetro parece ser critíca, quando são realizados experiências com seca prolongada ou quando a prática de irrigação é limitada. Isto pode resultar num desenvolvimento das raízes das culturas não similar ao encontrado no campo. Como Van Bavel (1961) ilustrou, a profundidade do lisímetro e sua drenagem são pontos críticos em relação a extração de água do solo. Quando o lençol freático não é desejável, é necessário um sistema de vácuo para manutenção de uma condição não saturada na parte inferior do lisímetro. Quando não ocorre limitação no fornecimento de água, a profundidade de $1 \mathrm{~m}$ é razoável.

As dimensões do lisímetro procuram minimizar os distúrbios no regime térmico do solo para evitar acréscimos significantes no processo de evapotranspiração (Black et al., 1968; Pruitt \& Angus, 1960; Van Bavel ,1961 ). Os efeitos térmicos do solo podem ser minimizados pelo design do equipamento. Por exemplo, as paredes de separação entre a parte externa e interna devem ter a menor espessura possível, devendo ter também o mínimo de elevação na superfície.

Allen \& Fisher (1992) desenvolveram um lisímetro de pesagem de célula de carga capaz de medir a evapotranspiração com uma precisão de 0.05 a $0.10 \mathrm{~mm}$. Os autores discutem aspectos referentes à operação e programação do datalogger para se obter alta precisão de medidas. Foram testadas duas configurações de instalação das células de carga: na superfície do solo e no fundo das caixas de medida. A instalação das células na superfície tem o inconveniente das medidas serem afetadas pela temperatura, 
embora a manutenção das células seja facilitada. No caso da instalação em profundidade, embora se resolva o problema da temperatura, dificulta-se a manutenção.

Uma alternativa para sanar esses inconvenientes pode ser a instalação das células de carga em superfície dentro de caixas isoladas termicamente.

\subsubsection{Estimativa da Evapotranspiração}

É grande o número de métodos de estimativa da evapotranspiração. Muitos desses métodos têm aceitação quase que unânime, enquanto outros são bastante criticados.

Segundo Pereira (1992), evapotranspiração é um assunto bastante simples do ponto de vista teórico, porém, no lado prático das medições torna-se bastante complexo e difícil.

Estudando a importância relativa de alguns parâmetros meteorológicos na estimativa da Evapotranspiração, Berlato \& Molion (1981) deram a seguinte ordem de grandeza para os parâmetros radiação líquida, umidade relativa e velocidade de vento: 80:6:14, ilustrando de forma bastante visível a importância da radiação no processo evapotranspirativo.

Segundo Villa Nova (1987), é difícil separar a ação de cada um desses elementos, pois os mesmos agem simultaneamente. De uma maneira geral, em uma dada região, quanto maior for a disponibilidade de energia solar, temperatura do ar, velocidade de vento, e quanto menor for a umidade relativa, maior deverá ser a taxa de evaporação/evapotranspiração.

Basicamente, pode se classificar os métodos de estimativa da evapotranspiração da seguinte forma (Pereira, 1994): a) Métodos empíricos: Tanque Classe A; Thornthwaite; Camargo; Makkink; Radiação Solar; Jensen-Haise; Linacre; HargreavesSamani è Blaney-Criddle b) Métodos de Balanço de Energia: Razão de Bowen e 
Priestley-Taylor; c) Método aerodinâmico; d) Métodos combinados: Penman; Slatyer \& Mc Ilroy; Penman simplificado e Penman Monteith e e) Método da Correlação dos Turbilhões.

Esses métodos acima citados determinam a evapotranspiração a partir de fórmulas empíricas ou semi-empíricas. A opção por um ou outro método dependerá, na maioria das vezes, da precisão requerida ou do tipo de dado climatológico disponível, uma vez que nenhum dos métodos propostos parece desfrutar de preferência absoluta.

Sedyama (1987) afirma que existem disponíveis cerca de 50 métodos para estimativa da evapotranspiração, podendo ser divididos em quatro classes: os métodos que tem como base a temperatura, (Thomthwaite e Blaney-Criddle), os métodos baseados em temperatura e radiação (Jensen-Haise, Makkink e Hargreaves), os métodos combinados que associam os efeitos do balanço de energia e os termos de energia convectiva para estimar as perdas de água de superfícies cultivadas (Penman), e os métodos de evaporação em tanques (Tanque USWB e Tanque Classe A).

Procurando sistematizar os procedimentos para estimativa da evapotranspiração de referência, Doorembos \& Pruitt (1977) selecionaram os métodos de Penman, de Blaney-Criddle, da radiação solar e do Tanque Classe A, calibrando-os com os valores medidos da evapotranspiração de grama, coletados em lisímetros, nos mais diferentes climas e regiões. Segundo esses autores, o método de Penman é o que melhor estima a Evapotranspiração de referência, seguido pelo método do tanque Classe A.

Segundo Luchiari \& Riha (1991), o método de Penman é amplamente utilizado, por que facilita o entendimento dos processos físicos da evaporação de superfícies naturais e, também, porque se utiliza de informações meteorológicas coletadas em um único nível acima da superfície evaporante.

Entretanto, apesar de apresentar um excelente desenvolvimento teórico e ser basicamente físico, o modelo de Penman não deixa de ser empírico, pelo fato de incorporar em sua estrutura a função velocidade do vento, relativa ao termo aerodinâmico da equação. Por esse fato, a maioria das versões conhecidas da equação 
original de Penman resulta de alterações na sua função velocidade do vento (Peres, 1994).

Procurando superar esta falta de generalidade da fórmula de Penman, coube a Monteith (1965) ${ }^{1}$, citado por Peres (1994), a obtenção de uma equação geral válida para qualquer tipo de vegetação, sob qualquer condição de stress hídrico. Esse modelo, que introduz no termo aerodinâmico duas resistências (resistência do dossel e aerodinâmica), foi chamado de Penman-Monteith, e passou a ser bastante utilizado nas estimativas da evapotranspiração.

É grande a quantidade de trabalhos existentes na literatura que se relacionam com comparações entre métodos de estimativa de evapotranspiração.

Avaliações feitas por Doorenbos \& Pruitt (1977) apresentaram como melhor método de estimativa de evapotranspiração de referência o método de Penman modificado, com erros ao redor de $10 \%$ no verão e até $20 \%$ sob condições de baixa demanda evaporativa.

Trabalhando com comparações entre métodos, Lima (1991) utilizou como padrão valores obtidos com evapotranspirômetros. Foram utilizados os métodos de Penmanpiche, Hargreaves, Priestley-Taylor e Camargo, concluindo-se que as melhores estimativas foram obtidas a partir dos métodos de Penman-piche e Camargo. A autora também introduziu a evaporação de Piche no modelo original de Camargo, obtendo assim melhores estimativas em relação ao modelo original.

As diferenças encontradas nos resultados pelos diversos métodos decorrem geralmente do fato de os mesmos serem utilizados em regiões diferentes da sua origem, transformando-se em motivo de preocupação para os pesquisadores, que têm desenvolvido estudos visando avaliar e ajustar as relações existentes (Silva, 1989).

No estudo de evapotranspiração em estufas, são poucos os trabalhos que têm seguido a metodologia de Doorembos \& Kassan (1979) para estimar o consumo de água pelas culturas. Segundo esses autores, o método do tanque evaporimétrico, juntamente

\footnotetext{
'MONTEITH, J.L. Evaporation and environment. Sump. Soc. Exp. Biology. London, 19: 205-34, 1965.
} 
com os métodos da Radiação Solar (FAO) e de Priestley-Taylor são os melhores para estimar a evapotranspiração de referência no interior de estufas. (Prados, 1986, citado por Farias et al., 1994) ${ }^{2}$

Com o objetivo de estudar a evapotranspiração da cultura do crisântemo em vaso, Fynn et al. (1993) instalaram equipamentos para medir alguns parâmetros climáticos dentro e fora de uma estufa de $7,3 \mathrm{~m}^{2}$ : velocidade do vento, temperatura do ar, temperatura do ponto de congelamento, concentração de $\mathrm{CO}_{2}$, evapotranspiração (lisímetro), temperatura da folha, índice de área foliar, radiação fotossinteticamente ativa e radiação solar global, sendo os dados coletados através de um "datalogger". A partir desses dados, calculou-se a evapotranspiração da cultura, utilizando-se um modelo derivado do método de Penman. Os autores concluíram que a equação combinada pode predizer com relativa exatidão as necessidades hídricas de uma cultura de crisântemo em vaso. Apesar disso, os autores citam a dificultade de se correlacionar a ET medida com o lisímetro e a ET calculada por métodos empíricos de estimativa, tendo em vista o grande número de fatores envolvidos.

Trabalhando com nove espécies ornamentais, Baille \& Baille (1992) estudaram a estimativa da evapotranspiração a partir de dados de temperatura do dossel, déficit de pressão de vapor e radiação líquida, comparando os resultados com medidas diretas (lisímetro de pesagem). A partir dos dados obtidos com sensores instalados interna e externamente à estufa, foram desenvolvidos dois modelos de estimativa da evapotranspiração: a) uso do modelo de Penman-Monteith, com uso de fórmulas empíricas para a estimativa da resistência do dossel $\left(r_{c}\right)$ e b) método baseado no balanço de vapor de água na estufa, tendo como entradas a taxa de troca de ar e a diferença entre a umidade específica interna e externa. Ambos os métodos apresentaram boas performances, quando comparados com os dados observados (lisímetro). O primeiro deles tem a vantagem de ser bastante simples e preciso, se a $r_{c}$ for corretamente estimada

\footnotetext{
${ }^{2}$ PRADOS, N.C. Contribucion al estudio de los cultivos enarenados en Almeria: necessidades hídricas y estración del nutrientes del cultivo de tomate de crescimento indeterminado en abrigo de polietileno. Almeria, Espana, 1986. 195p. Tesis (Doutorado em Fitotecnia), Caja Rural Provincial, Almeria, 1986.
} 
através de equações específicas, e se a medida ou estimativa da radiação líquida for disponível. O segundo método tem o inconveniente da dificuldade da estimativa da taxa de troca de ar na estufa.

Estudando elementos meteorológicos que influem na Evapotranspiração, Baille (1992) afirma que a temperatura do ar não é um indicador muito preciso do estado da água na planta. Os parâmetros mais úteis são o déficit de pressão de vapor (DPV), que caracteriza o estado da água no ar e os parâmetros de radiação, facilmente acessíveis como a radiação global (Rs) ou a radiação líquida $(\mathrm{Rn})$. Esses parâmetros são necessários em modelos de estimativa da evapotranspiração, visando a obtenção da demanda climática ou evapotranspiração potencial, tão bem quanto a evapotranspiração atual. Equações mais acuradas e elaboradas, baseadas no balanço de energia da cultura podem ser usadas, requerindo não somente medidas de DPV e Rs (ou Rn), mas também estimativas do índice de área foliar (IAF) e valores de referência para a resistência aerodinâmica $\left(\mathrm{r}_{\mathrm{a}}\right)$ e resistência interna mínima $\left(\mathrm{r}_{\mathrm{c}}\right)$ da cultura.

\subsection{Radiação solar no interior de estufas}

Segundo Martin et al. (1982), a densidade de fluxo de radiação solar no interior da estufa é menor que a verificada externamente, devido à reflexão e à absorção do material de cobertura plástica.

O material plástico mais empregado atualmente na agricultura em nível mundial é o polietileno de baixa densidade (PEBD). O PEBD é um material que apresenta boa transparência à radiação solar, deixando passar em média 70 a $80 \%$ da radiação solar, podendo este percentual atingir, no máximo, 95\% (Martin \& Robledo, 1981).

Também com relação ao PEBD, Buriol et al. (1993) afirma que, além da alta transparência à radiação solar global incidente (70 a 90\%), esse material também 
apresenta transparência semelhante para a radiação de onda longa (cerca de $80 \%$ ), o que provoca o efeito chamado inversão térmica.

Esse fenômeno não ocorre em ambientes abertos, pois os ventos renovam constantemente a camada de ar junto à superfície, evitando que a temperatura mínima do ar seja muito baixa externamente. Já dentro da estufa não é verificada renovação similar, ocasionando um esfriamento progressivo e ininterrupto do ar, devido às perdas por radiação e condução e convecção através do plástico, resultando em valores mais baixos de temperatura mínima dentro da estufa.

Robledo (1987), comparando vários tipos de plásticos, verificou uma perda média variando de 10 a 17\% na transmissividade, enquanto que Farias et al. (1993), utilizando polietileno de baixa densidade (PEBD), verificou uma redução de 10 a 35\% na transmissividade no intervalo de 11 a 13 horas, e de $17 \%$ em média ao longo do dia.

De uma maneira geral, pode-se dizer que a quantidade de energia solar não transmitida é devido ao tipo de cobertura e ao ângulo de incidência dos raios solares, o que é condicionado pela orientação da estufa, pela inclinação do telhado e pela posição do sol. (Hanan et al., 1978 e Robledo \& Vicente, 1988)

Apesar da redução da radiação solar global no interior da estufa, Farias et al. (1993) encontrou um maior valor da razão entre radiação difusa e total (Rd/Rs) dentro da estufa, sendo este fator muito importante, pois a radiação difusa é multidirecional podendo ser melhor aproveitada pelas plantas. Esta relação $\mathrm{Rd} / \mathrm{Rs}$ pode variar bastante entre os diferentes tipos de plásticos, variando de $15 \%$ para polietileno normal (sem aditivo) até $65 \%$ para alguns materiais.

Segundo Jones (1992), existem quatro principais caminhos pelos quais a radiação interfere no comportamento das culturas, sendo que os três mais importantes no caso do presente estudo são:

1. Efeitos térmicos. A radiação é o principal modo de troca de energia entre as plantas e o ambiente aéreo; a radiação solar é a principal fonte de energia para as plantas e a maior parte dessa energia é convertida em calor, impulsionando o processo de 
transpiração e também alterando a temperatura dos tecidos vegetais com consequências para a taxa dos processos metabólicos e o balanço entre eles.

2. Fotossíntese. Uma parte da radiação solar absorvida pelas plantas é usada na síntese de ligações químicas ricas em energia e componentes reduzidos de carbono. Este processo (fotossíntese) é característico de plantas e é a principal fonte de energia livre na biosfera.

3. Fotomorfogênese. A quantidade e distribuição da radiação de onda curta tem também uma importante função no crescimento e desenvolvimento das plantas.

\subsection{Umidade do ar no interior de estufas}

Em estudos feitos com estufas com cobertura plástica na Região Sul do Brasil, Farias et al. (1993b), encontraram maiores valores de umidade relativa máxima, que ocorreram no período noturno, no interior da estufa, devido a maior concentração de vapor d'água. Segundo Robledo \& Vicente (1988), isto ocorre devido à pequena permeabilidade do plástico à água e à baixa taxa de renovação do ar no interior da estufa.

De uma maneira geral, no interior de estufas são encontrados em média, valores mais elevados de umidade relativa no período noturno e da manhã e valores praticamente iguais no período mais quente do dia, quando se compara com o ambiente externo (Montero et al., 1985).

\subsection{Temperatura do ar no interior de estufas}

A temperatura do ar no interior de estufas está intimamente ligada ao balanço de energia, que por sua vez, depende de vários fatores, como o tamanho da estufa, as 
propriedades óticas da cobertura e as condições meteorológicas locais. (Buriol et al., 1993)

Durante o dia, devido à radiação líquida positiva, a superfície aquece a parcela de ar próxima a ela, gerando assim um processo convectivo. Na estufa, este processo é interrompido pela cobertura plástica, que impede a saída do ar quente, o que provoca a ocorrência de altas temperaturas no período diurno, podendo ser bem maior que as verificadas em ambiente externo.

Dependendo das condições atmosféricas, a temperatura noturna no interior da estufa pode ser menor que à temperatura externa. Isso pode acontecer em noites com ventos moderados ou fortes associados com céu limpo, pois na condição interior a perda acentuada de energia e a ausência de turbulência causam uma inversão térmica. (Montero et al., 1985; Mills et al., 1990 ; Farias et al., 1993b e Buriol et al, 1993)

No período noturno, a vedação da estufa pode influenciar no comportamento da temperatura do ar, principamente em noites com ventos moderados e fortes (Robledo \& Vicente, 1989 e Farias et al., 1993b)

\subsection{Uso de Estações automáticas para controle da irrigação}

Com o aumento do uso de microcomputadores na agricultura, tornou-se possível uma manipulação de dados mais simples e eficiente.

Um método de controle da irrigação bastante promissor é a coleta e armazenamento de dados provenientes de estações agrometeorológicas automáticas, calculanto-se posteriormente qualquer parâmetro necessário para um manejo eficiente da irrigação.

Segundo Hubbard et al. (1982), o uso de computadores para facilitar a coleta de dados e informações climatológicas é importante desde a década passada. Avanços tecnológicos nessa área têm contribuído para reduzir os custos dos equipamentos e 
aumentar a performance dos mesmos. O autor descreve o funcionamento do AWDN (Automated weather data Network), uma estação de trabalho que registra e manipula dados provindos de redes de estações meteorológicas automáticas para a região centronorte dos EUA.

Howell et al. (1985) descreveram a instalação e operação de estações automáticas nos propósitos de controle de irrigação. Nesse trabalho, os autores descrevem todas as etapas do processo de utilização de dados de estações automáticas para controle da irrigação. Em cada estação instalada, foram medidos os seguintes parâmetros: a) radiação solar; b) radiação líquida; c) temperatura do ar a $1.5 \mathrm{~m}$ de altura; d) umidade relativa a $1.5 \mathrm{~m}$ de altura : e) velocidade do vento a $2.0 \mathrm{~m}$ de altura; f) direção do vento a $2.0 \mathrm{~m}$ de altura; g) precipitação; $\mathrm{h}$ ) temperatura do solo a $0.02 \mathrm{~m}$ profundidade; i) temperatura do solo a $0.15 \mathrm{~m}$ de profundidade. Os autores concluíram que a performance global dos sistemas automáticos de aquisição de dados tem sido bastante satisfatória para os propósitos desejados.

Hubbard et al. (1982) afirma que as estações automáticas consistem em vários instrumentos meteorológicos montados numa torre de $3 \mathrm{~m}$. Um anemômetro (canecas) e um cata-vento são utilizados para medir a velocidade e direção do vento, respectivamente, e são montados no alto da torre. Temperatura do ar, umidade e radiação solar são medidos a $1.5 \mathrm{~m}$. A temperatura do ar é medida com um termômetro enquanto que o sensor de umidade é um higrômetro eletrônico. Esse sensores são instalados num pequeno abrigo meteorológico. A radiação global é medida com um piranômetro de silicone montado numa superfície horizontal. Uma sonda de temperatura do solo (termistor protegido) é instalado a uma profundidade de $10 \mathrm{~cm}$ abaixo da superfície do solo. Cada estação é também equipada com um pluviômetro de caçamba, para medir a precipitação. O mecanismo de medida registra mudanças de precipitação a cada $1 \mathrm{~mm}$ de chuva.

Bausch (1990) observou que, apesar das estações meteorológicas automáticas estarem se tornando comuns para medir parâmetros meteorológicos, não existem padrões 
para a instalação dos sensores, no que diz respeito à altura dos mesmos na estação. $\mathrm{O}$ autor desenvolveu um estudo para verificar as diferenças nos cálculos de ET de referência para alfafa, medindo temperatura do ar e umidade relativa a 1,5 e $2,5 \mathrm{~m}$ de altura e velocidade do vento a 2,0 e 3,0m de altura. A ET calculada a partir da altura de $2,0 \mathrm{~m}$ dos sensores de temperatura do ar e umidade relativa foi $2,2 \%$ maior que a calculada para $1, .5 \mathrm{~m}$. A velocidade do vento medida a $3,0 \mathrm{~m}$ provocou mudanças da ordem de $1 \%$ quando comparada a medidas feitas a $2,0 \mathrm{~m}$. O autor concluiu, a partir dos valores de ET calculados que a altura dos sensores não contribuiu significativamente nas variações de ET. Entretanto, recomenda que a altura dos sensores deve ser padronizada para as instalações de estações automáticas.

Campbell \& Tanner (1981) discutem aspectos operacionais das estações automáticas, principalmente no que se refere ao design estrutural das mesmas. Segundo o autor, o avanço tecnológico nessa área tem proporcionado muitas alternativas para satisfazer as necessidades das estações meteorológicas automáticas. Alguns dos critérios mais utilizados para selecionar os elementos a serem empregados numa estação são: facilidade de interface, custo, consumo de energia e durabilidade em condições ambientais adversas. Tendo em vista a grande diversidade de elementos passíveis de utilização na montagem de uma estação dessa natureza, a maior preocupação do autor é com a padronização dos equipamentos utilizados, para que as medições provenientes desses sistemas sejam confiáveis e exatas. $\mathrm{O}$ autor também define alguns critérios para a escolha dos sensores, obedecendo a seguinte ordem de prioridade: precisão, custo, manutenção e consumo de energia.

Hubbard et al. (1982) afirmaram que as estações automáticas, além da obtenção de dados climáticos, podem ser utilizadas para a aquisição de muitas outras informações, que devem ser sempre relacionadas com as condições específicas do local de instalação, como localização da estação no campo, cultura implantada, condições climáticas, etc.

A sequência de obtenção de dados pode ser vista na Figura 1. Os dados obtidos pela estação são armazenados num microprocessador (Datalogger), que monitora esses 
dados, calculando as médias e os totais no tempo previamente programado. Um computador conectado ao datalogger, através de cabo telefônico, recebe as informações, que serão processadas, fornecendo o resultado da evapotranspiração do período, bem como outros parâmetros importantes para o monitoramento agroclimatológico. Numa etapa posterior, a informação é repassada aos diversos tipos de usuários. Com a estimativa da demanda hídrica do período, recomenda-se então a frequência e a quantidade de água a ser fornecida à cultura.

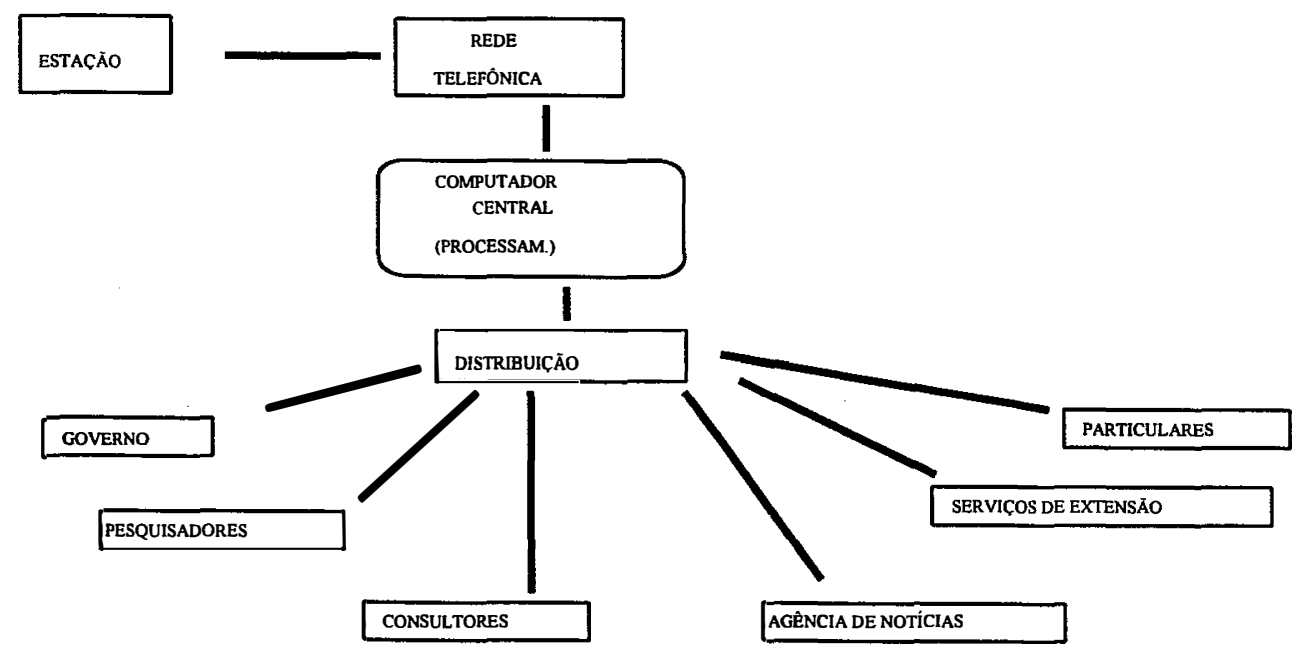

Figura 1 -Esquema de aquisição de dados através de estações automáticas 


\section{MATERIAL E MÉTODOS}

\subsection{Local e instalações}

O experimento foi conduzido numa estufa de crisântemo da propriedade de Schoenmaker Van Zanten - Cooperativa Holambra, em Arthur Nogueira - SP (10 Km do município de Holambra), a $22^{\circ}$ de latitude sul, com uma altitude de $600 \mathrm{~m}$, no período de 15 de setembo a 05 de dezembro de 1995.

Schoenmaker-Van Zanten é uma "joint venture" entre duas empresas no ramo de produção de flores, sendo a primeira delas brasileira e a segunda holandesa, e hoje ocupa a posição de maior produtora de mudas de crisântemos com 2.000 .000 de mudas semanais para o mercado interno e externo(Holanda, Inglaterra, Argentina e Japão).

A unidade de Arthur Nogueira conta com uma área total de 12 ha sendo utilizado para cultivo 2.8 ha de campo e 3.8 ha de estufa, que possui uma produção de mudas mais regular e de melhor qualidade devido a um maior controle de pragas e doenças.

A estufa onde foi realizado o experimento é do tipo Poly-Vento (Capela) com módulos múltiplos de $6,40 \mathrm{~m}$ de largura e múltiplos de $3,66 \mathrm{~m}$ de comprimento, possuindo dimensões de $89,60 \mathrm{~m}$ de largura (14 módulos) por $62,22 \mathrm{~m}$ de comprimento (17 módulos), perfazendo uma área de $5.575 \mathrm{~m}^{2}$ (Figura 1) e com altura do pé direito de $5,0 \mathrm{~m}$. O plástico utilizado como cobertura é do tipo PEBD de $150 \mu \mathrm{m}$ (ou $0,150 \mathrm{~mm}$ ). As parcelas de produção são divididas em áreas de $375 \mathrm{~m}^{2}$ (2 módulos de $6,40 \mathrm{~m}$ x 8 
módulos de 3,66m) numa das quais foram instalados os equipamentos e monitorados os fatores climáticos, o desenvolvimento e consumo de água da cultura.

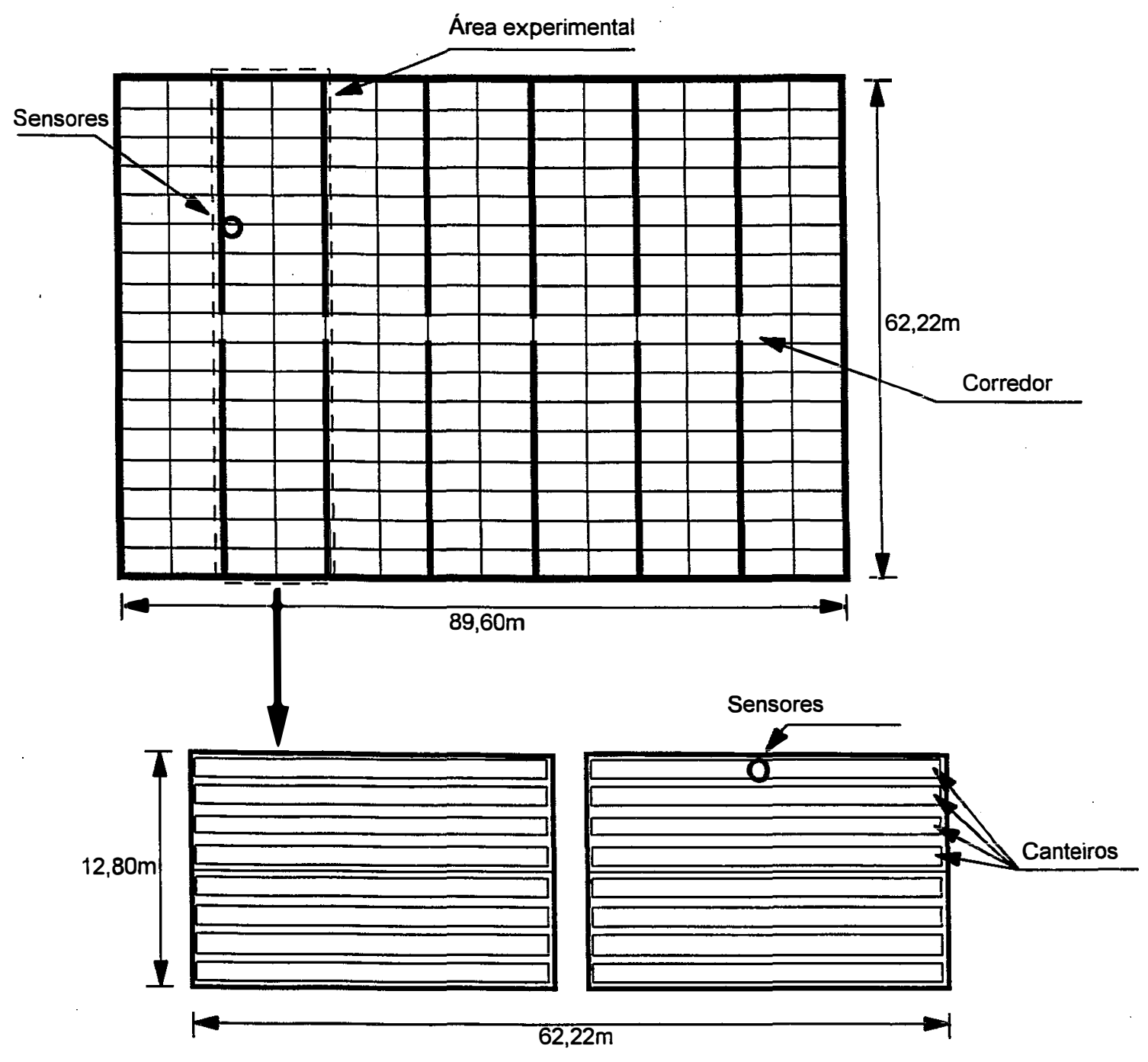

Figura 2 - Dimensão total da estufa

\subsection{Caracterização da cultura}


A cultura implantada na estufa foi o crisântemo variedade Shuriky, plantado em canteiros de $1,30 \mathrm{~m}$ de largura, com espaçamento entre as plantas de $0,12 \mathrm{~m} \times 0,12 \mathrm{~m}$.

O plantio foi realizado, à partir de estacas enraizadas, em 07 de setembro de 1995 e a cultura foi monitorada a partir de 15 de setembro até 05 de dezembro de 1995 .

Com relação ao cultivo, o crisântemo é considerada como de fotoperíodo negativo, ou de dias curtos, com período crítico de 13 horas de iluminação. Assim, quando exposta à luz por períodos acima de 13 horas, ocorre o crescimento vegetativo, e, quando exposta a períodos abaixo de 13 horas diárias, é induzida ao florescimento. Essa sensibilidade à luz difere entre espécies e variedades.

O fornecimento artificial de luz é utilizado principalmente no sistema de produção de mudas, sendo feito através de lâmpadas incandescentes comuns, ao longo dos canteiros de plantio. Sua distribuição deve ser feita de modo que a planta receba um iluminamento em torno de $300 \mathrm{lux}$ (lúmen $/ \mathrm{m}^{2}$ ). No inverno, são fornecidas 4 horas de luz durante a noite, enquanto que no verão são fornecidas 3 horas. Quando se deseja obter dias curtos, utiliza-se geralmente plástico ou pano preto, que recobrem totalmente o canteiro.

Além do comprimento do dia, influem também no crescimento e florescimento do crisântemo fatores como a temperatura, umidade relativa e quantidade de $\mathrm{CO}_{2}$. Quanto à temperatura, pode-se dizer que o nível ótimo para o crescimento está em torno de 21 a $24{ }^{\circ} \mathrm{C}$, sendo que em temperaturas inferiores a $20{ }^{\circ} \mathrm{C}$, o processo de desenvolvimento de raízes já é prejudicado. $\mathrm{O} \mathrm{CO}_{2}$ influi diretamente no crescimento, uma vez que é um dos reagentes no processo de fotossíntese. Quando não há limitações quanto ao nível de água e radiação, o $\mathrm{CO}_{2}$ se torna o fator limitante da fotossíntese, sendo que em alguns casos pode ser viável a sua aplicação artificial no ambiente.

A planta pode ser cultivada em qualquer época do ano. Uma semana após o transplante, faz-se o desponte manual, com o intuito de quebrar a dominância apical, ficando a planta com 5 folhas. Ao fim de três semanas a partir do desponte, começa a colheita das mudas. O primeiro "flush" (colheita) é a mais produtiva, com uma média de 
2 a 3 mudas por planta, ocorrendo uma queda abrupta no segundo "flush". A partir dessa segunda colheita, ocorre uma retomada na produtividade, obtendo-se cerca de 1 a 1,5 mudas/semana/planta. O ciclo total varia entre 15 a 20 semanas, época em que o matrizeiro se encontra bastante desenvolvido $(30$ a $40 \mathrm{~cm}$ ), saindo então de produção.

Com relação às doenças, pode-se citar a ferrugem, a rizoctonia e o mofo cinzento como as principais. $\mathrm{O}$ tripes, o bicho mineiro, os ácaros e a mosca branca são as pragas de maior importância no cultivo do crisântemo.

O objetivo principal de um cultivo de crisântemo de corte é a obtenção de estacas padronizadas, que são vendidas em saquinhos com aproximadamente 50 mudas. A boa qualidade e padronização das mudas são requisitos muito importantes, sendo descartadas as estacas muito finas ou velhas, e também aquelas com inserções defeituosas. O que geralmente se faz em propriedades comerciais é o escalonamento do plantio, para que seja possível a obtenção de mudas durante todo o período de exigência do mercado.

Essa cultura, embora também cultivada em condições de campo, é preferencialmente conduzida em condições climáticas controladas, ou seja, em casas de vegetação ou estufas.

\subsection{Práticas culturais adotadas no cultivo}

A sequência de práticas culturais adotada pela empresa no cultivo de crisântemo de corte pode ser vista a seguir:

1. Roçada da cultura anterior.

2. Adição de matéria orgânica tratada na forma de esterco curtido, casca de eucalipto, pó de xaxim e adubo. A quantidade é de $8 \mathrm{~m}^{3^{3}}$ por estufa $\left(770 \mathrm{~m}^{2}\right)$.

3. Escarificação do solo a uma profundidade aproximada de $30 \mathrm{~cm}$.

4. Pulverização do solo e incorporação dos restos de cultura e da matéria orgânica adicionada com enxada rotativa. 
5. Desinfecção do solo por tratamento com Brometo de metila (durante 1 semana) ou com vapor d'água (durante cerca de 6 horas).

6. Adubação (110 g/m $\mathrm{m}^{2}$ de Superfosfato triplo $+120 \mathrm{~g} / \mathrm{m}^{2}$ de Nitromag)

7. Preparo dos canteiros para plantio manual das mudas sendo cerca de 2600 mudas por canteiro que totaliza 41600 mudas por estufa.

\subsubsection{Controle Fitossanitário}

O controle fitossanitário foi sempre preventivo, uma vez que a empresa não pode correr nenhum tipo de risco de contaminação nas mudas a serem comercializadas, devido à grande exigência de qualidade do mercado, principalmente o mercado externo ( Japão, Holanda e Inglaterra). Desse modo, foram feitas duas aplicações semanais com misturas de inseticidas e fungicidas bem como duas ou mais aplicações de DDVP (Dichlorvos) na forma de "fog" para controle principalmente do tripes.

\subsubsection{Colheita das mudas}

As mudas foram colhidas com $5 \mathrm{~cm}$ de comprimento, sendo então acondicionadas em sacos plásticos (53 mudas/embalagem), já tratadas com ácido Indolbutírico para facilitar o enraizamento. Logo após a colheita, os sacos com as mudas foram levados para uma câmara fria à uma temperatura média de $4^{\circ} \mathrm{C}$, onde permaneceram até a fase de enraizamento. Foram colhidas mudas obtidas com cada um dos manejos de irrigação utilizados: 1) manejo adotado convencionalmente pela empresa e 2) manejo proposto, a partir das leituras do lisímetro de pesagem. 


\subsection{Sistema de irrigação}

O sistema de irrigação é constituído de:

- 2 bombas KSB 40-160 com motor Weg10 CV

- 3 sistemas de filtragem ( 2 de tela e um de discos)

- linhas de aspersores modelo Mamkad (vazão de 240 1/h) com espaçamento de $3.5 \times 6.5$ metros

- linhas de gotejadores modelo ASBRASIL de vazão de 4 1/h (quatro linhas com $40 \mathrm{~cm}$ entre gotejadores por canteiro)

As áreas de campo são irrigadas somente com o sistema de aspersão enquanto que nas estufas estão presentes os dois sistemas (aspersão e gotejamento).

Nas primeiras semanas após o plantio as irrigações foram diárias e por aspersão pois as plantas ainda não tinham seu sistema radicular desenvolvido. A fertirrigação só começou a ser utilizada depois da segunda semana e sua concentração foi controlada através da condutividade elétrica da água, que variou de $0 \mathrm{mS} / \mathrm{cm}$ no início até 1.7 a 2.0 $\mathrm{mS} / \mathrm{cm}$ para os estágios mais avançados da cultura.

A partir da quarta ou quinta semana, as irrigações por aspersão foram sendo gradativamente substituídas pela irrigação localizada (gotejamento),que passou a ser utilizada exclusivamente (no caso das estufas), sendo a aspersão utilizada apenas uma vez por semana com o intuito de lavar as folhas devido as pesadas aplicações de defensivos na cultura.

Os principais adubos utilizados, bem como suas concentrações estão dispostos na Tabela 1 . 
Tabela 1 - Adubos utilizados e suas concentrações no tanque de fertirrigação.

\begin{tabular}{|c|c|}
\hline TIPODE ADUBO & $\begin{array}{c}\text { QUANTIDADE } \\
\text { (kg/500 litros) }\end{array}$ \\
\hline Nitrato de potássio & 25,0 \\
\hline Nitrato de amônio & 25,0 \\
\hline MAP (monoamônio fosfato) & 5,0 \\
\hline Sulfato de magnésio & 15,0 \\
\hline Sulfato de zinco & 0,150 \\
\hline Sulfato de cobre & 25,0 \\
\hline Bórax & 0,170 \\
\hline Molibdato de sódio & 5,0 \\
\hline Uréia & 8,0 \\
\hline
\end{tabular}

\subsection{Materiais}

\subsubsection{Evapotranspiração da cultura (ETc) medida:}

A Evapotranspiração da cultura foi obtida a partir de dados coletados em um lisímetro de pesagem com célula de carga, instalado num dos canteiros experimentais no interior da estufa. Os dados obtidos a partir do lisímetro foram tomados como referência para as estimativas da evapotranspiração.

O lisímetro foi desenvolvido no Departamento de Engenharia Rural da Escola Superior de Agricultura "Luiz de Queiroz".

Este lisímetro foi montado com um recipiente cilíndrico interno de $0,58 \mathrm{~m}$ de diâmetro e $0,30 \mathrm{~m}$ de altura e um recipiente cilíndrico externo de $0,62 \mathrm{~m}$ de diâmetro e 0,50m de altura (Figura 3). Entre os recipientes foi colocada uma estrutura metálica de 
sustentação e transmissão da carga para uma célula de carga HAINCO modelo HS150, com capacidade máxima de $150 \mathrm{~kg}$, e precisão de $0,1 \mathrm{~mm}$.

A estrutura metálica, com base quadrada de $0,41 \mathrm{~m}$ de lado, foi construida com perfis tipo "U" em aço, com dois braços em forma de "V" apoiados em quatro pontos na base e convergindo para o ponto de apoio da célula de carga. Sobre os dois braços em forma de "V" foram colocados quatro parafusos com altura regulável para apoiar o recipiente interno e nivelá-lo (Figura 4).

O lisímetro foi instalado com sua face superior no mesmo nível que o canteiro, enterrando-se o recipiente externo no solo. Abaixo do lisímetro foi feito um buraco para a drenagem da água aplicada.

A calibração do lisímetro foi feita, inicialmente em laboratório, com pequenos sacos de areia de massa conhecida (25g) sendo colocados sobre a estrutura até um total de $1500 \mathrm{~g}$ e posteriormente repetida após a instalação no campo. A partir dos resultados obtidos foi determinada uma equação para transformação dos sinais da célula de carga em milivolts (mV) para massa (g) (Figura 5) e depois transformados em milímetros de água. A calibração foi feita em dois sentidos: primeiramente se adicionando os pesos em ordem crescente, de 25 em $25 \mathrm{~g}$, e depois em ordem decrescente, retirando-se os pesos em tempos predeterminados. 


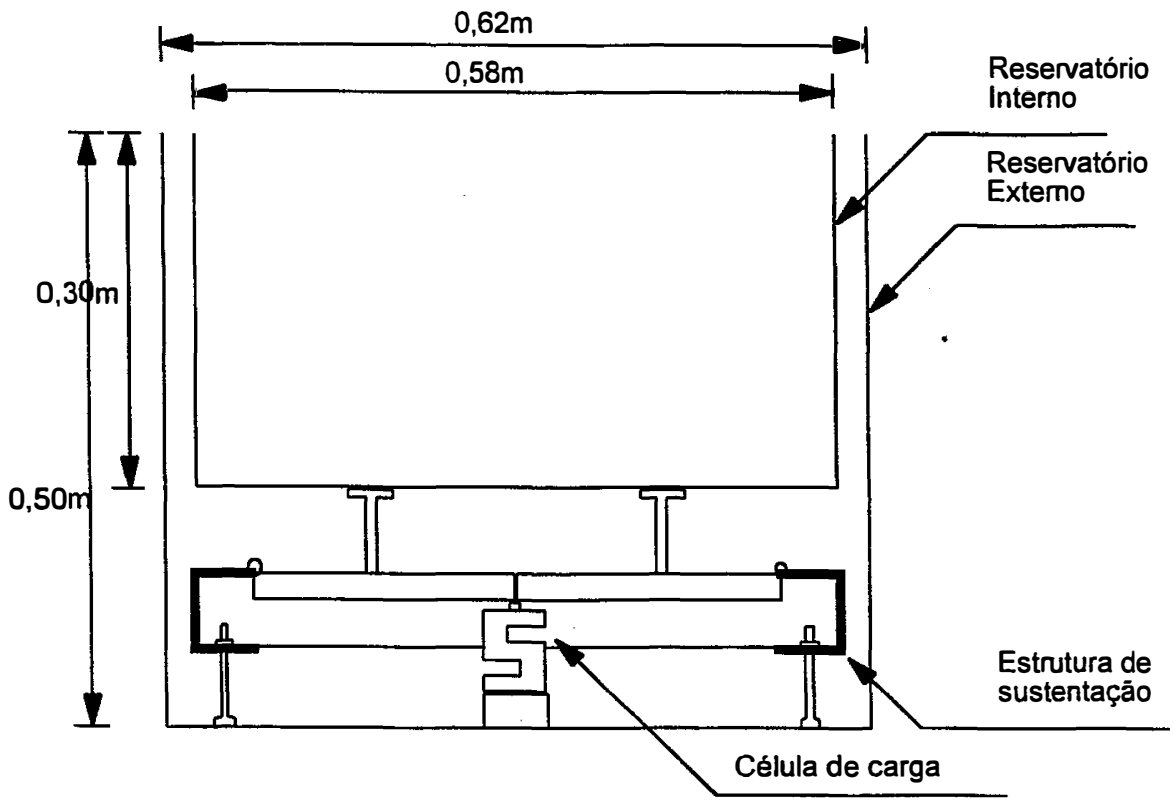

Figura 3 - Corte transversal do lisímeto.

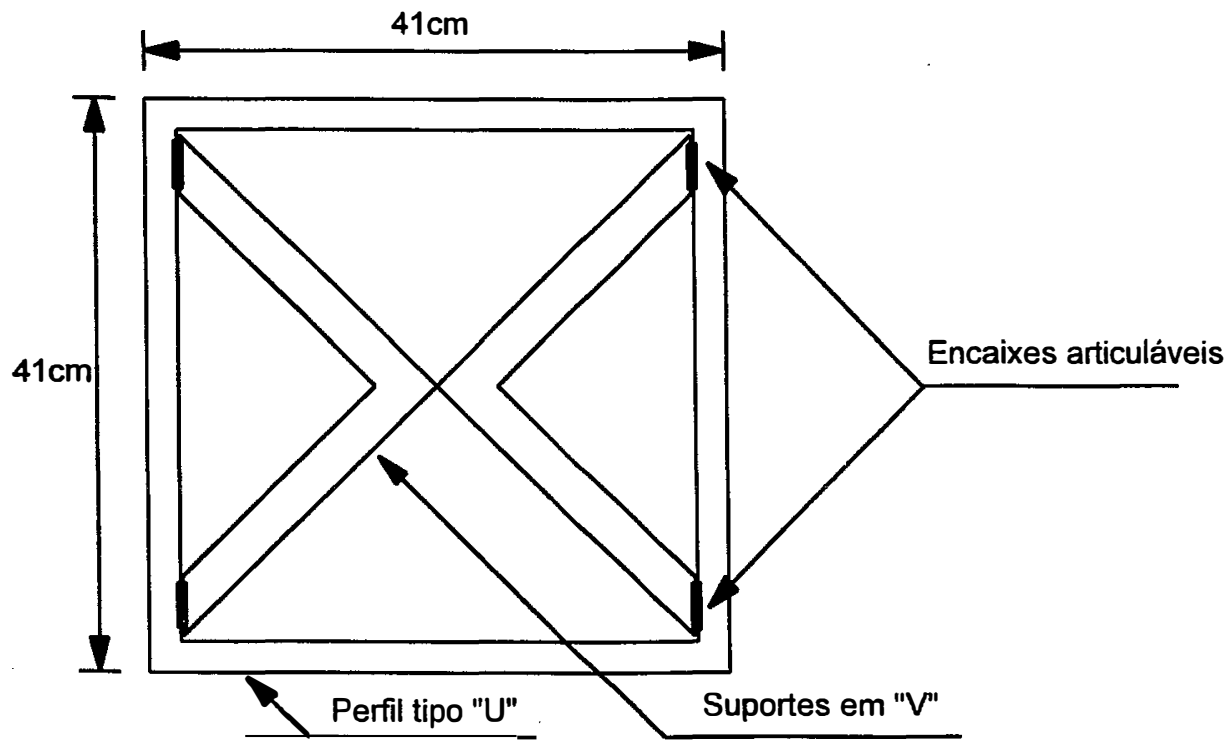

Figura 4 - Detalhe da estrutura de sustentação do lisímetro.

Este equipamento foi ligado a um sistema de aquisição de dados ("datalogger") e programado de forma a obter dados médios a intervalos de 1 hora. Estes resultados 
foram convertidos para lâmina de água $(\mathrm{mm})$, através de um fator multiplicador (obtido na curva de calibração).

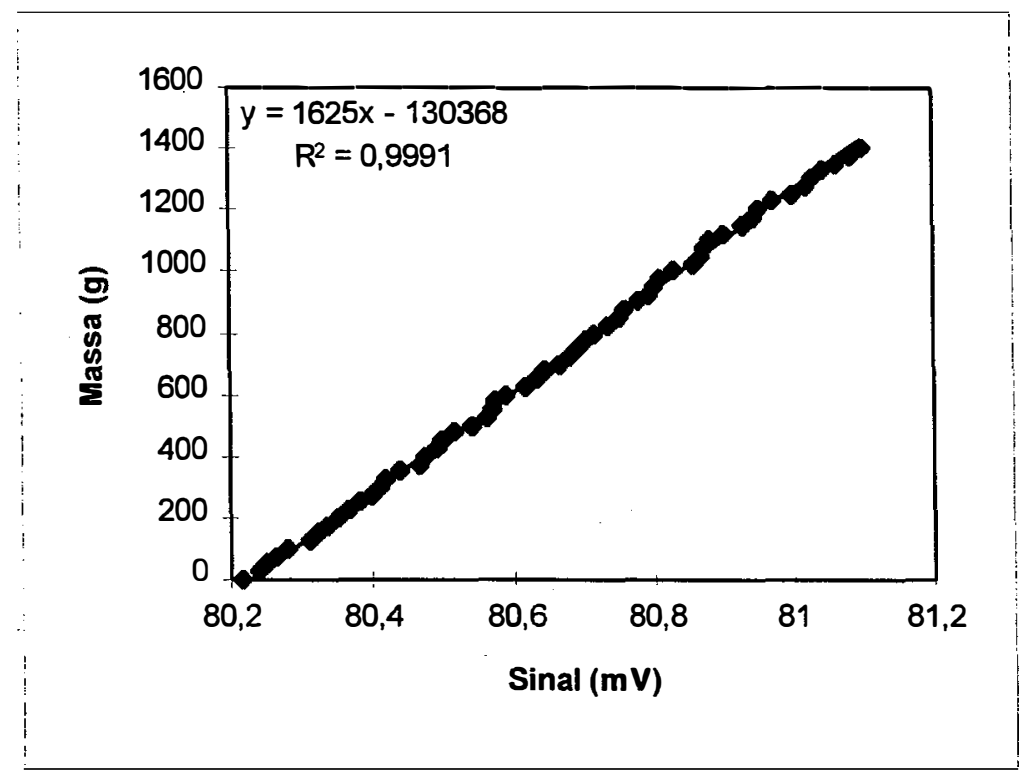

Figura 5 - Calibração do lisímetro

\subsubsection{Obtenção dos dados meteorológicos}

As informações meteorológicas utilizadas neste trabalho foram através de um sistema de aquisição de dados modelo CR-10 da Campbell Scientific, no qual foram conectados os seguintes sensores de medida ( Figura 6).

\section{- Externos à estufa}

1. Velocidade e direção do vento, medidos a 7,2 $\mathrm{m}$ de altura ( Wind Monitor-JR model 04101- YOUNG), com faixa de leitura de 0 a $60 \mathrm{~m} / \mathrm{s}$ e sensibilidade de $1,3 \mathrm{~m} / \mathrm{s}$.

2. Temperatura do ar e umidade relativa do ar, medidos a 7,2 $\mathrm{m}$ de altura ( CS-500 Temperature and Relative Humidity Probe - Campbell Scientific), com faixa de leitura de 10 a $100 \%$ para umidade relativa, com precisão de $\pm 2 \%$ a $10 \%$ e $\pm 3 \%$ a 
$90 \%$. A faixa de leitura de temperatura do sensor é de -40 até $+60^{\circ} \mathrm{C}$, com precisão de $\pm 0.5^{\circ} \mathrm{C}$ a $-40^{\circ} \mathrm{C} ; \pm 0.4^{\circ} \mathrm{C}$ a $-20^{\circ} \mathrm{C}$ e $\pm 0.6^{\circ} \mathrm{C}$ a $60^{\circ} \mathrm{C}$.

3. Radiação global, medida a 7,2 m de altura ( LI- 200SZ Pyranometer sensor Campbell Scientific), com faixa de operação de -40 a $65^{\circ} \mathrm{C}$, com sensibilidade de 0,2 $\mathrm{kW} \cdot \mathrm{m}^{-2} \cdot \mathrm{V}^{-1}$

\section{- No interior da estufa}

4. Temperatura e Umidade relativa (Temp./Relative Humidity Probe model 41327YOUNG), instalados a 1,5m de altura, com faixa de medida de 0 a $100 \%$ de umidade relativa, com precisão de $2 \%$ para medidas de 0 a $90 \%$ e $3 \%$ para medidas de 90 a $100 \%$. A faixa de medida para temperatura é de -50 a $50^{\circ} \mathrm{C}$, com precisão de $\pm 0,3^{\circ} \mathrm{C}$ a $20^{\circ} \mathrm{C}$.

5. Radiação global ( LI- 200SZ Pyranometer sensor - Campbell Scientific)

6. Lisímetro de pesagem por célula de carga; de marca HAINCO, modelo HS 150, com capacidade máxima de $150 \mathrm{~kg}$, e precisão de $0,1 \mathrm{~mm}$

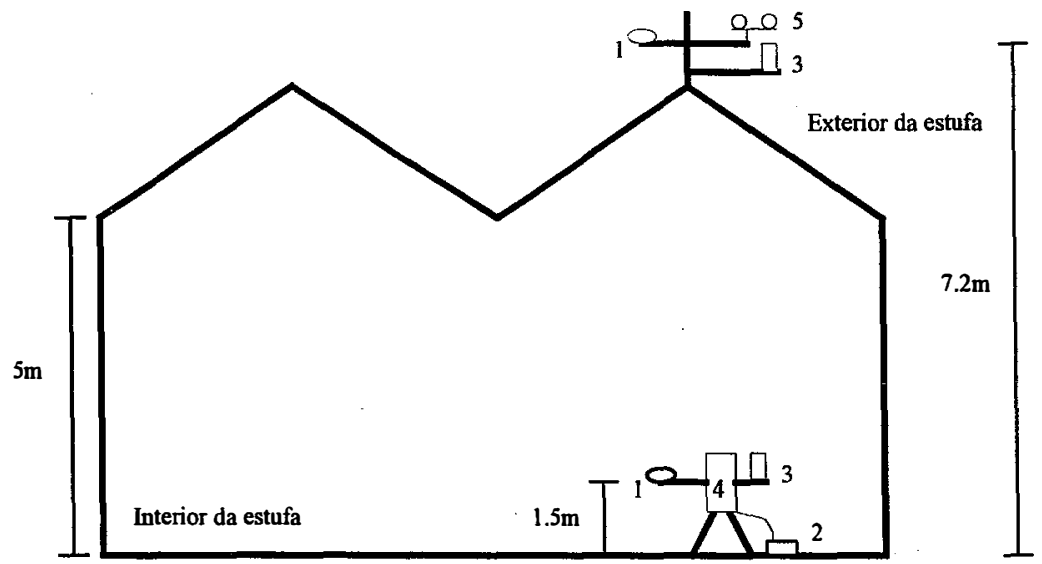

1. Radiação global

2. Lisímetro de pesagem com célula de carga

3. Umidade Relativa e Temperatura do ar

4. Datalogger

5. Velocidade e direção do vento

Figura 6 - Disposição dos sensores no interior e fora da estufa 
No interior da estufa (área experimental), os sensores tiveram a seguinte disposição (Figura 7):

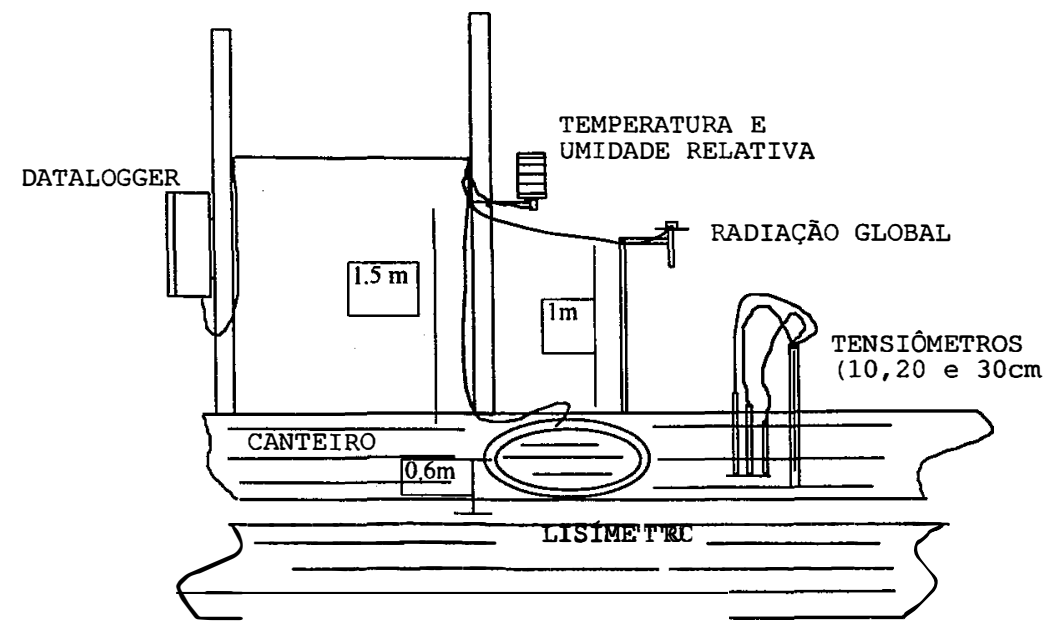

Figura 7 - Disposição dos sensores no canteiro no interior da estufa

Esses equipamentos foram instalados tomando-se sempre o cuidado de evitar interferências das bordas e das estruturas da estufa. Os sensores instalados na parte externa foram colocados a 7,2 metros em função de se evitar interferências das construções sobre as medidas.

\subsubsection{Outros equipamentos instalados}

\subsubsection{Tanque evaporimétrico}

Foi instalado um Tanque de evaporação com medidas menores que o Tanque Classe A, no interior da estufa, tendo como bordadura os próprios canteiros de crisântemo. $O$ Tanque tem $50 \mathrm{~cm}$ de diâmetro e $25 \mathrm{~cm}$ de altura. As leituras foram feitas diariamente às $\mathbf{8}$ horas através de um parafuso micrométrico de gancho com precisão de medidas de até $0.02 \mathrm{~mm}$. 


\subsubsection{Tensiômetros}

Foram instaladas duas baterias de tensiômetros dentro da área experimental, no interior da estufa. Cada bateria foi composta por três tensiômetros instalados a 10, $20 \mathrm{e}$ $30 \mathrm{~cm}$ de profundidade. As leituras foram feitas diariamente, às 8 horas.

Os objetivos da utilização dos tensiômetros foram avaliar a tensão da água do solo, procurando evitar valores muito elevados que pudessem afetar o desenvolvimento da cultura e também observar a movimentação vertical da água para baixo do sistema radicular.

Os resultados do monitoramento da tensão da água no solo (Figura 8), mostram que as tensões foram sempre baixas, com valores médios em torno de $20 \mathrm{kPa}$, atingindo valores um pouco maiores apenas no nível de $10 \mathrm{~cm}$, em curtos períodos.
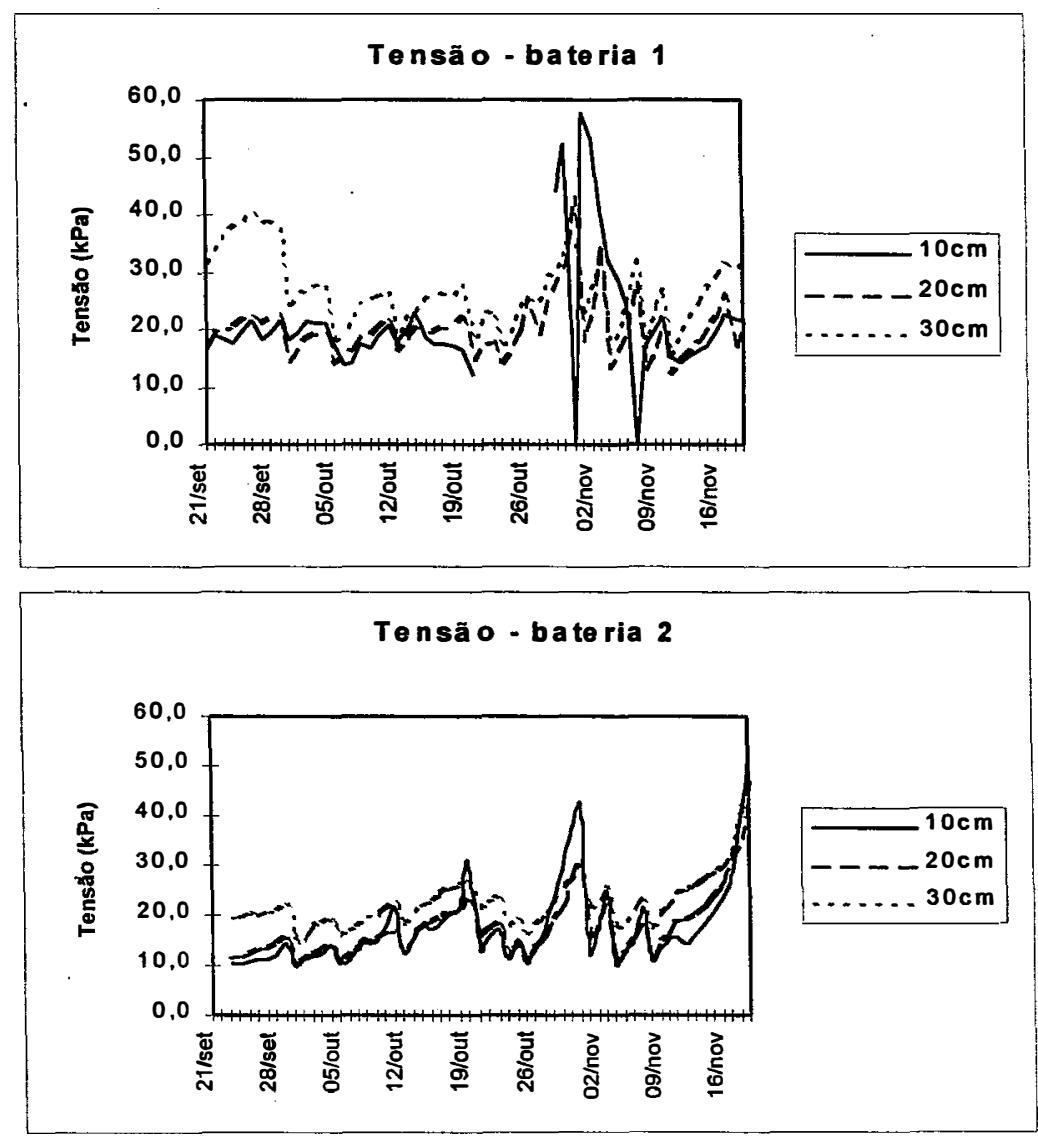

Figura 8 - Potencial da água no solo, em atm. 
Os resultados das tensões da água no solo mostram que a cultura foi sempre bem suprida de água, não havendo déficit que pudesse prejudicar seu desenvolvimento ou que alterasse significativamente a evapotranspiração.

\subsubsection{Evaporímetro de Piche}

Com o objetivo de medir o poder evaporante do ar à sombra, foi instalado próximo aos canteiros experimentais um evaporímetro de Piche, a uma altura de $1.5 \mathrm{~m}$, dentro de um abrigo, que foi fixado num dos mourões de sustentação da estufa.

Este equipamento consiste de um tubo de vidro calibrado e fechado numa das extremidades. O tubo é cheio de água destilada, sendo fechado com um papel de filtro circular preso com uma mola. O papel umidecido evapora, baixando o nível de água dentro do tubo. Medidas consecutivas permitem calcular a evaporação no período desejado, um dia no caso específico deste trabalho.

\subsection{Metodologia}

\subsubsection{Avaliação do sistema de irrigação}

O sistema de aspersão é composto por emissores modelo Mamkad, de fabricação da DAN SPRINKLERS (Israel), com vazão de $240 \mathrm{l} / \mathrm{h}$ e espaçamento de $6,40 \mathrm{~m}$ x 3,66m. Portanto a taxa média de aplicação de água é de $10,25 \mathrm{~mm} / \mathrm{h}$.

Para avaliação do sistema de irrigação por aspersão foram instalados 180 coletores $($ diâmetro $=80 \mathrm{~mm}$ ) espaçados de $1,07 \mathrm{~m} \times 1,00 \mathrm{~m}$, num total de 4 linhas de coletores entre duas linhas de emissores espaçadas de $6,40 \mathrm{~m}$. Os aspersores funcionaram por cerca de 15 e 20 minutos em cada um dos testes. Foram determinados os valores do 
coeficiente de uniformidade de Christiansen (CUC) em ambos os testes como podemos observar no Tabela 2.

Tabela 2 - Teste de uniformidade de aplicação da lâmina de irrigação para os aspersores tipo Mamkad.

\begin{tabular}{|c|c|c|c|}
\hline TESTE & $\begin{array}{c}\text { NÚMERO DE } \\
\text { COLETORES }\end{array}$ & DURACÃO (min) & CUC (\%) \\
\hline $1(15 / 09 / 95)$ & 100 & $15 \mathrm{~min}^{*}$ & $91.9 \%$ \\
\hline $2(26 / 09 / 95)$ & 134 & $20 \mathrm{~min}^{*}$ & $89.8 \%$ \\
\hline
\end{tabular}

*tempos de irrigação geralmente utilizados no manejo da cultura

Os valores de CUC maiores que $90 \%$ indicam que o sistema de irrigação por aspersão tem um funcionamento satisfatório, aplicando uma lâmina bastante homogênea na área.

O sistema de gotejamento é composto por gotejadores tipo labirinto modelo GT, de fabricação da ASBRASIL (Brasil), com vazão de 3,81/h (14,4m.c.a.). O espaçamento entre os emissores é de $0,40 \mathrm{~m}$ na linha e $0,32 \mathrm{~m}$ entre linhas (4 linhas de gotejadores por canteiro).

Para avaliação do sistema de irrigação por gotejamento foram instalados coletores e medidas as vazões em cinco pontos na linha de gotejadores, dispostos no início da linha, a $25 \%$ do comprimento, $50 \%$ do comprimento, $75 \%$ do comprimento e no final da linha. Foram avaliadas as 4 linhas do canteiro onde foi instalado o lisímetro (Tabela 3).

A partir dessas lâminas, foi calculado o CUC do sistema de gotejamento, que para o ensaio foi igual a 94,1\%, com uma vazão média de 3,36 litros/h e uma lâmina média de $25,92 \mathrm{~mm} / \mathrm{h}$. O coeficiente de uniformidade obtido $(94,1 \%)$ indica um bom funcionamento do sistema de gotejamento empregado nos canteiros experimentais. 
Tabela 3 - Teste de uniformidade de aplicação de lâmina de água no gotejamento.

\begin{tabular}{|c|c|c|c|c|c|}
\hline Pontos & $\begin{array}{c}\text { Linha 1 } \\
(\mathbf{m l})\end{array}$ & $\begin{array}{c}\text { Linha 2 } \\
(\mathbf{m l})\end{array}$ & $\begin{array}{c}\text { Linha 3 } \\
\mathbf{( m l )}\end{array}$ & $\begin{array}{c}\text { Linha 4 } \\
(\mathbf{m l})\end{array}$ & Pressão(Kgf/cm2) \\
\hline 1 & 348 & 348 & 266 & 362 & 1.19 \\
\hline 2 & 362 & 304 & 350 & 352 & 1.10 \\
\hline 3 & 356 & 348 & 358 & 340 & 1.07 \\
\hline 4 & 336 & 342 & 348 & 348 & 1.07 \\
\hline 5 & 262 & 332 & 322 & 354 & 1.05 \\
\hline
\end{tabular}

\subsubsection{Análise Física do solo}

Para as análises físicas do solo foram retiradas três amostras deformadas, coletada em cinco pontos dentro da área experimental, às profundidades de $0-5 \mathrm{~cm}, 5$ $10 \mathrm{~cm}$ e $10-15 \mathrm{~cm}$ para a análise granulométrica; cinco amostras indeformadas à profundidade de $0-5 \mathrm{~cm}$ para a determinação da curva de retenção; e duas amostras indeformadas nas profundidades de $0-10 \mathrm{~cm}$, para a determinação da condutividade hidráulica saturada e densidade do solo. Também foi determinada a velocidade de infiltração básica do solo.

A curva de retenção de água no solo está representada na Figura 9. Esta curva é característica de um solo arenoso, com $65 \%$ de areia, onde se verifica uma redução da intensidade de movimento de água com a diminuição da umidade do solo, sendo esta faixa de transição bem nítida. Os dados obtidos na análise laboratorial foram ajustados pelo modelo de Van Genuchten, obtendo-se um $\mathrm{r}^{2}$ de 99,0 \% (Figura 9).

Com os dados de areia, argila e silte obtidos na análise granulométrica, chegouse à classificação do solo em questão como franco-argilo-arenoso, por interpolação no diagrama para determinação da classe textural dos solos (MEDINA, 1967). 
Tabela 4 - Análise granulométrica média do solo

\begin{tabular}{|c|c|c|c|}
\hline AMOSTRA: \% ARGIIA & \% SIITE & \% AREIA : \\
\hline $0-5 \mathrm{~cm}$ & 23,41 & 11,59 & 65,00 \\
\hline $5-10 \mathrm{~cm}$ & 24,57 & 13,14 & 62,29 \\
\hline $10-15 \mathrm{~cm}$ & 19,76 & 17,15 & 63,09 \\
\hline
\end{tabular}

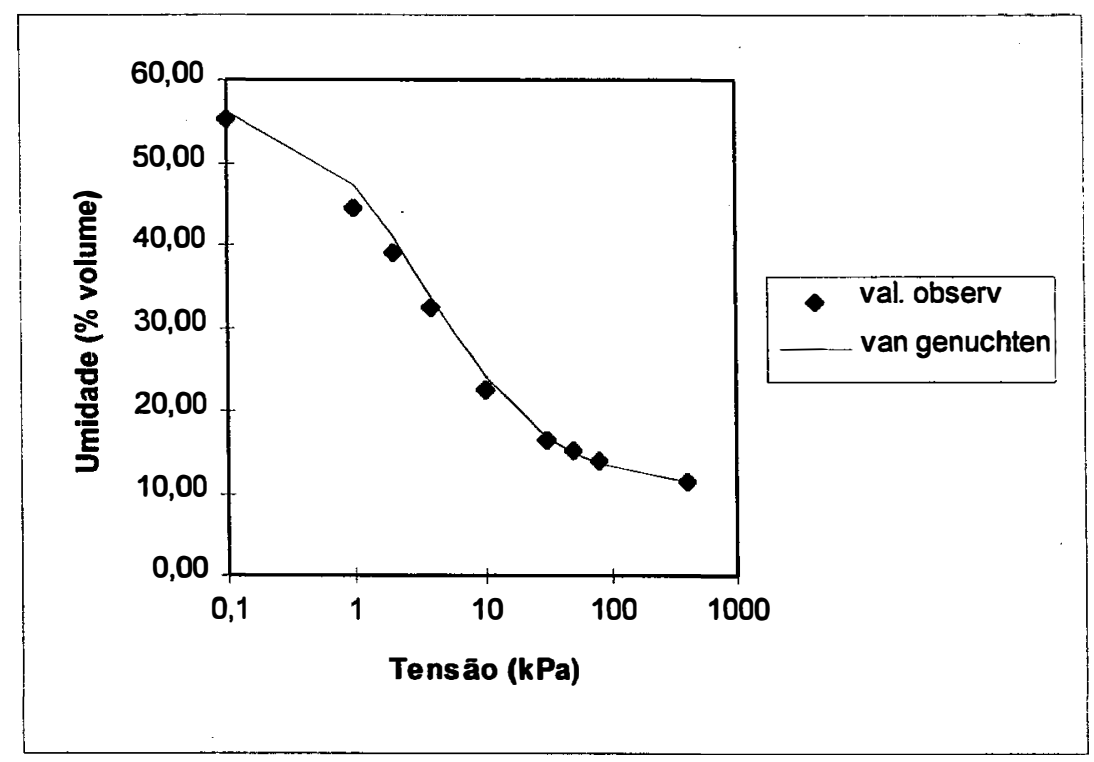

Figura 9 - Curva de retenção da água no solo

No Tabela 5 encontram-se os resultados das análises de condutividade hidráulica saturada e densidade global do solo.

Tabela 5 - Condutividade hidráulica, e densidade global do solo.

\begin{tabular}{|c|c|c|}
\hline & Condutividade hidraulica saturada & $\begin{array}{l}\text { Densidade global } \\
:=\left(9.9 \mathrm{~cm}^{3}\right)\end{array}$ \\
\hline AMOSTRA 1 & 19,53 & 1,32 \\
\hline AMOSTRA 2 & 21,55 & 1,39 \\
\hline
\end{tabular}


Outra análise física foi a determinação em dois pontos da estufa da velocidade de infiltração básica de água no solo através do método do anéis concêntricos. (Tabela $6 \mathrm{e}$ Figuras 10 e 11)

Tabela 6 - Testes de infiltração de água no solo.

\begin{tabular}{|c|c|c|c|c|}
\hline $\begin{array}{c}\text { Tempo } \\
\text { INST } \\
\text { (min) }\end{array}$ & $\begin{array}{c}\text { Tempo } \\
\text { ACUM } \\
\text { (min) }\end{array}$ & $\begin{array}{c}\text { INF. } \\
\text { INST. } \\
(\mathbf{c m})\end{array}$ & $\begin{array}{c}\text { INF. } \\
\text { ACU. } \\
(\mathbf{c m})\end{array}$ & $\begin{array}{c}\text { VEL. } \\
\text { INF. } \\
(\mathbf{c m} / \mathbf{m i n})\end{array}$ \\
\hline 0 & 0 & 0 & 0 & \\
\hline 1 & 1 & 1 & 1 & 1 \\
\hline 1 & 2 & 0.8 & 1.8 & 0.8 \\
\hline 2 & 4 & 1.1 & 2.9 & 0.55 \\
\hline 2 & 6 & 1.4 & 4.3 & 0.7 \\
\hline 5 & 11 & 3.3 & 7.6 & 0.66 \\
\hline 5 & 16 & 2.5 & 10.1 & 0.5 \\
\hline 10 & 26 & 5.6 & 15.7 & 0.56 \\
\hline 10 & 36 & 4.5 & 20.2 & 0.45 \\
\hline 15 & 51 & 6 & 26.2 & 0.4 \\
\hline 15 & 66 & 6 & 32.2 & 0.4 \\
\hline 30 & 96 & 9.6 & 41.8 & 0.32 \\
\hline 30 & 126 & 9.2 & 51 & 0.307 \\
\hline 30 & 156 & 9.6 & 60.6 & 0.32 \\
\hline 30 & 186 & 8.7 & 69.3 & 0.29 \\
\hline 30 & 216 & 9.2 & 78.5 & 0.307 \\
\hline & & & & \\
\hline
\end{tabular}

\begin{tabular}{|c|c|c|c|c|}
\hline \multicolumn{5}{|c|}{ TESTE 2} \\
\hline Tempo & Tempo & INF. & INF. & VEL. \\
\hline INST & ACUM & INST. & ACU. & INF. \\
\hline$(\min )$ & . $(\min )$ & (cm) & (cm) & $(\mathrm{cm} / \mathrm{min}$ \\
\hline 0 & 0 & 0 & 0 & \\
\hline 1 & 1 & 1.2 & 1.2 & 1.2 \\
\hline 1 & 2 & 0.8 & 2 & 0.8 \\
\hline 2 & 4 & 0.7 & 2.7 & 0.35 \\
\hline 2 & 6 & 0.7 & 3.4 & 0.35 \\
\hline 5 & 11 & 1.7 & 5.1 & 0.34 \\
\hline 5 & 16 & 1.3 & 6.4 & 0.26 \\
\hline 10 & 26 & 2.4 & 8.8 & 0.24 \\
\hline 10 & 36 & 2.7 & 11.5 & 0.27 \\
\hline 15 & 51 & 2.9 & 14.4 & 0.19 \\
\hline 15 & 66 & 3 & 17.4 & 0.20 \\
\hline 30 & 96 & 4.6 & 22 & 0.15 \\
\hline 30 & 126 & 5.7 & 27.7 & 0.19 \\
\hline 30 & 156 & 6 & 33.7 & 0.20 \\
\hline 30 & 186 & 4.9 & 38.6 & 0.16 \\
\hline 30 & 216 & 5.2 & 43.8 & 0.17 \\
\hline 30 & 246 & 5 & 48.8 & 0.17 \\
\hline
\end{tabular}




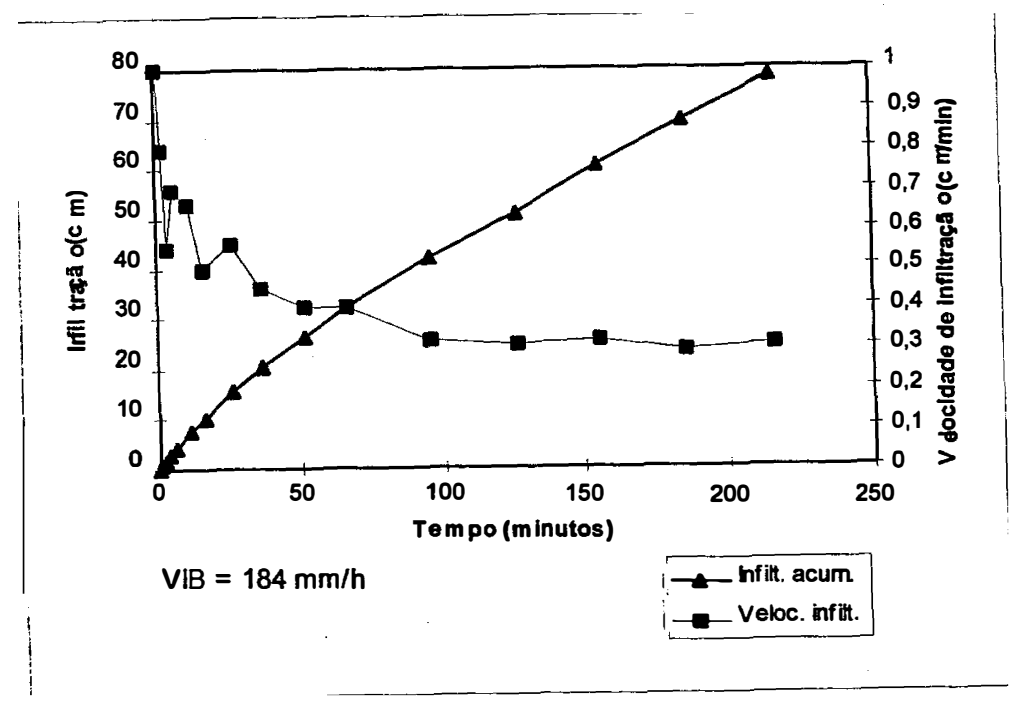

Figura 10 - Teste (1) de infiltração de água no solo.

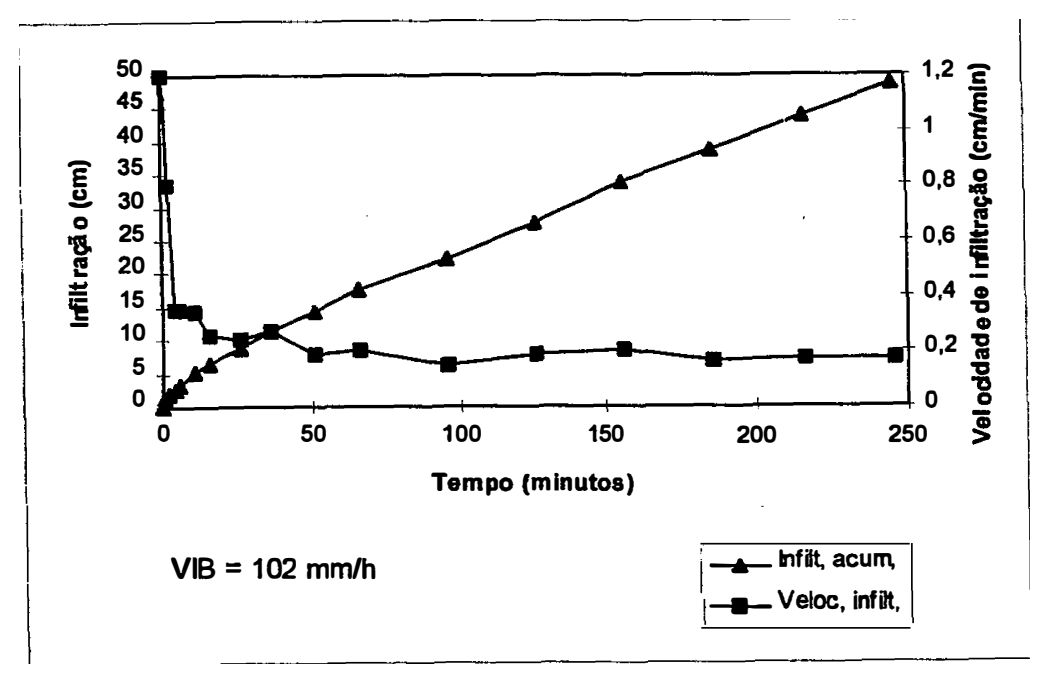

Figura 11 - Teste (2) de infiltração de água no solo.

As velocidades de infil ração básica (VIB) encontradas nos dois pontos foram de $184.2 \mathrm{~mm} / \mathrm{h}$ e $102 \mathrm{~mm} / \mathrm{h}$, conforme mostram as Figuras 7 e 8. Esses valores são bastante altos estando próximos de valores de infiltração de areia. Isso pode ser explicado não só pelas características físicas desse solo (Tabelas 4 e 5), mas também, se levarmos em conta o manejo da cultura e as práticas adotadas pela empresa adicionado uma grande quantidade de matéria orgânica $\left(10 \mathrm{~kg}\right.$ de esterco de curral curtido por $\left.\mathrm{m}^{2}\right)$ a cada ciclo 
da cultura além do revolvimento do solo com enxada rotativa contribuindo para $o$ aumento da sua macroporosidade.

\subsubsection{Determinação do índice de área foliar}

$\mathrm{O}$ índice de área foliar foi determinado pelo método destrutivo à partir de amostras coletadas em intervalos de aproximadamente 15 dias, onde 10 plantas foram coletadas ao acaso e suas folhas separadas. Das folhas foram retiradas circunferências de área conhecida e todo o material foi posto para secar em estufa a $65^{\circ} \mathrm{C}$ durante um período de 72 horas, fazendo-se a correlação entre o peso seco das circunferências e o peso seco total da planta.

A partir dos valores do IAF foi determinada uma equação de regressão para estimativa do valor diário do IAF ( $\mathrm{m}^{2}$ de folha $/ \mathrm{m}^{2}$ de solo).

Esses valores podem ser visualizados na Figura 9, que relaciona dias após o plantio (DAP) com o índice de área foliar (IAF).

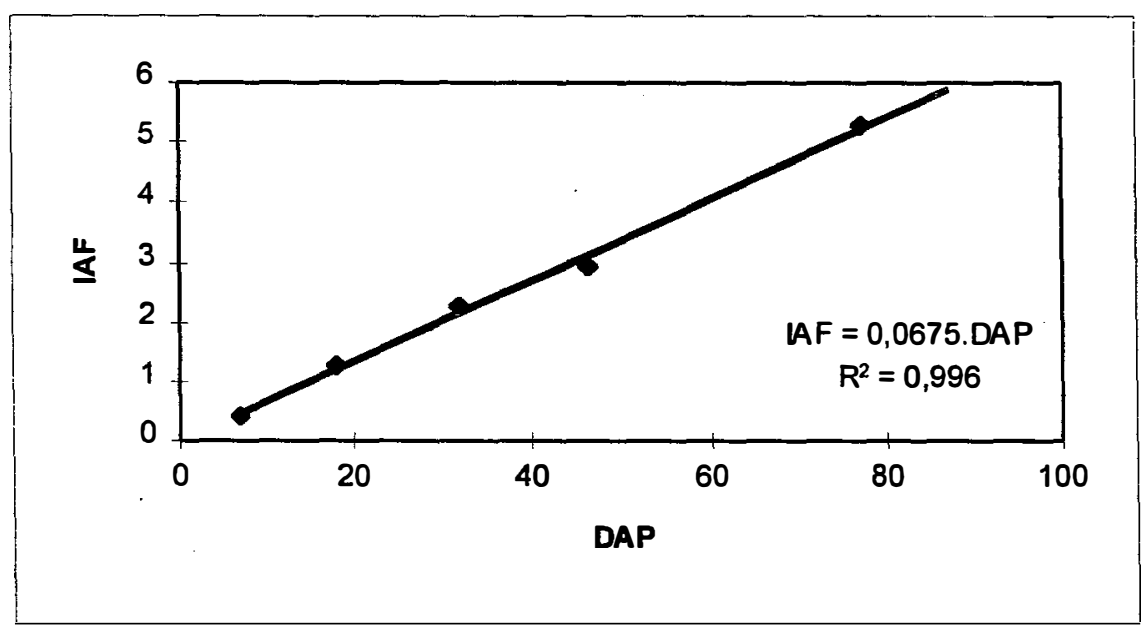

Figura 12 - Índice de área foliar X dias após o plantio 
3.6.4. Métodos de estimativa da Evapotranspiração potencial

A partir dos dados obtidos com o uso dos sensores, estimou-se a evapotranspiração potencial no interior da estufa, utilizando-se os seguintes métodos:

\subsubsection{Método do tanque evaporimétrico}

Este é um método bastante utilizado e recomendado pela FAO (Doorenbos \& Kassan ,1979). É utilizado tanto para estimar a evaporação de um lago, como a evapotranspiração de uma cultura bem suprida de água. A evaporação medida no tanque (ECA) deve ser corrigida por um coeficiente $(\mathrm{Kp})$, isto é:

$$
E T c a=K p \cdot E C A
$$

Para as condições deste trabalho, foram adotados os seguintes valores, a partir dos dados da Tabela 7: para UR\% $<40, \mathrm{Kp}=0,7$; para UR\% entre 40 e $70, \mathrm{Kp}=0,8$ e para $\mathrm{UR} \%>70 \%, \mathrm{Kp}=0,85$.

\subsubsection{Método de Camargo}

O autor se baseou nos resultados da equação de Thornthwaite, propondo uma fórmula mais simples, porém com a mesma eficiência (Camargo \& Camargo, 1983). A ET (mm/dia), segundo esses autores, é dada pela eq. (2):

$$
E T c a m=F . Q o . T .
$$


Foram utilizados os seguintes fatores de ajuste para a temperatura: para $\mathrm{T}=23^{\circ} \mathrm{C}$, $\left.\mathrm{F}=0,01 ; \mathrm{T}=24^{\circ} \mathrm{C}, \mathrm{F}=0,0105 ; \mathrm{T}=25^{\circ} \mathrm{C}, \mathrm{F}=0,011 ; \mathrm{T}=26^{\circ} \mathrm{C}, \mathrm{F}=0,0115 ; \mathrm{T}>26^{\circ} \mathrm{C}, \mathrm{F}=0,012\right)^{3}$ Os dados de radiação extraterrestre foram obtidos a partir da Tabela 8.

Tabela 7 - Valores de coeficientes de tanque (Kp), com base nas condições diárias de vento e umidade relativa do ar, para tanque classe A instalado em área vegetada com grama ou em lavoura de baixo porte.

\begin{tabular}{|c|c|c|c|c|c|}
\hline \multirow[b]{2}{*}{ Vento } & \multirow[b]{2}{*}{ UR } & \multicolumn{4}{|c|}{ Largura da area vegetada ao redor do tanque } \\
\hline & & $1 \mathrm{~m}$ & $10 \mathrm{~m}$ & $100 \mathrm{~m}$ & $1000 \mathrm{~m}$ \\
\hline \multirow{3}{*}{$\begin{array}{l}\text { Leve } \\
<2,0 \mathrm{~m} / \mathrm{s}\end{array}$} & $<40 \%$ & 0,55 & 0,65 & 0,70 & 0,75 \\
\hline & 40 a $70 \%$ & 0,65 & 0,75 & 0,80 & 0,85 \\
\hline & $>70 \%$ & 0,75 & 0,85 & 0,85 & 0,85 \\
\hline \multirow{3}{*}{$\begin{array}{l}\text { Moderado } \\
2,0 \text { a } 4,9 \mathrm{~m} / \mathrm{s}\end{array}$} & $<40 \%$ & 0,50 & 0,60 & 0,65 & 0,70 \\
\hline & 40 a $70 \%$ & 0,60 & 0,70 & 0,75 & 0,80 \\
\hline & $>70 \%$ & 0,65 & 0,75 & 0,80 & 0,80 \\
\hline \multirow{3}{*}{$\begin{array}{l}\text { Forte } \\
>4,9 \mathrm{~m} / \mathrm{s}\end{array}$} & $<40 \%$ & 0,45 & 0,55 & 0,60 & 0,65 \\
\hline & 40 a $70 \%$ & 0,50 & 0,60 & 0,65 & 0,70 \\
\hline & $>70 \%$ & 0,60 & 0,65 & 0,70 & 0,75 \\
\hline
\end{tabular}

Fonte: Doorembos e Kasam, 1979

\subsubsection{Método de Makkink}

Utilizando dados de evapotranspiração potencial de um gramado com lisímetro de lençol freático constante, Makkink (1957) obteve uma correlação entre a ETP diária ( $\mathrm{mm} /$ dia) e a radiação solar ao nível da superfície, isto é:

\footnotetext{
${ }^{3}$ PEREIRA, A.R. (Departamento de Física e Meteorologia ESALQ/USP) Comunicação pessoal, 1996
} 


$$
E T m a k=0,61 \cdot W \cdot R s-0,12
$$

Tabela 8 - Radiação extraterrestre (Q) em milímetros de evaporação equivalente no dia 15 de cada mês, para o hemisfério Sul.

\begin{tabular}{|c|c|c|c|c|c|c|c|c|c|c|c|c|}
\hline \multirow{2}{*}{$\begin{array}{c}\text { Latitude } \\
\text { (\%) }\end{array}$} & \multicolumn{12}{|c|}{ MESES } \\
\hline & Jan. & Fev. & Mar. & $\mathrm{Abr}$ & Mai. & Jun. & Jul. & Ago. & Set. & Out. & Nov. & Dez. \\
\hline 0 & 14,5 & 15,2 & 15,2 & 14,7 & 13,9 & 13,4 & 13,5 & 14,2 & 14,9 & 14,9 & 14,5 & 14,3 \\
\hline 2 & 14,8 & 15,2 & 15,2 & 14,5 & 13,6 & 13,0 & 13,2 & 14,0 & 14,8 & 15,0 & 14,8 & 14,6 \\
\hline 4 & 15,0 & 15,3 & 15,1 & 14,3 & 13,3 & 12,7 & 12,8 & 13,7 & 14,7 & 15,1 & 15,0 & 14,9 \\
\hline 6 & 15,3 & 15,4 & 15,1 & 14,1 & 13,0 & 12,6 & 12,5 & 13,5 & 14,6 & 15,1 & 15,2 & 15,1 \\
\hline 8 & 15,6 & 15,6 & 15,0 & 14,0 & 12,7 & 12,0 & 12,2 & 13,2 & 14,5 & 15,2 & 15,4 & 15,4 \\
\hline 10 & 15,9 & 15,7 & 15,0 & 13,8 & 12,4 & 11,6 & 11,9 & 13,0 & 14,4 & 15,3 & 15,7 & 15,7 \\
\hline 12 & $\overline{15,1}$ & 15,8 & 14,9 & 13,5 & 12,0 & 11,2 & 11,5 & 12,7 & 14,2 & 15,3 & 15,8 & 16,0 \\
\hline 14 & 16,3 & 15,8 & 14,9 & 13,2 & 11,6 & 10,8 & 11,1 & 12,4 & 14,0 & 15,3 & 15,9 & 16,2 \\
\hline 16 & 16,5 & 15,9 & 14,8 & 13,0 & 11,3 & 10,4 & 10,8 & 12,1 & 13,8 & 15,3 & 16,1 & 16,4 \\
\hline 18 & 16,7 & 15,9 & 14,7 & 12,7 & 10,9 & 10,0 & 10,4 & 11,8 & 13,7 & 15,3 & 16,2 & 16,7 \\
\hline 20 & 16,7 & 16,0 & 14,5 & 12,4 & 10,6 & 9,6 & 10,0 & 11,5 & 13,5 & 15,3 & 16,4 & 16,8 \\
\hline 22 & 16,9 & 16,0 & 14,3 & 12,0 & 10,2 & 9,1 & 9,6 & 11,1 & 13,1 & 15,2 & 16,5 & 17,0 \\
\hline 24 & 16,9 & 15,9 & 14,1 & 11,7 & 9,8 & 8,6 & 9,1 & 10,7 & 13,1 & 15,1 & 16,5 & 17,1 \\
\hline 26 & 17,0 & 15,9 & 13,9 & 11,4 & 9,4 & 8,1 & 8,7 & 10,4 & 12,8 & 15,0 & 16,6 & 17,3 \\
\hline 28 & 17,1 & 15,8 & 13,7 & 11,1 & 9,0 & 7,8 & 8,3 & 10,0 & 12,6 & 14,9 & 16,6 & 17,5 \\
\hline 30 & 17,2 & 15,7 & $13,5^{\circ}$ & 10,8 & 8,5 & 7,4 & 7,8 & 9,6 & 12,2 & 14,7 & 16,7 & 17,6 \\
\hline
\end{tabular}

\subsubsection{Método da Radiação Solar}

Também conhecido como método FAO-24 da radiação, trata-se de uma adaptação feita por Doorenbos \& Pruitt (1975) no método de Makkink, substituindo os coeficientes $\underline{\mathrm{a}}$ e $\underline{\mathrm{b}}$ por um parâmetro $\underline{\mathrm{c}}$, que é função da umidade relativa do ar e da velocidade do vento, Logo, a equação simplificada se reduz a:

$$
\text { ETrad }=c \cdot W \cdot R s
$$


Com o intuito de evitar interpolações em nomogramas e tabelas, Frevert et al. $(1983)^{4}$, citado por Pereira, (1994), desenvolveu um sistema de equações de regressão múltipla, podendo a evapotranspiração ser calculada pela seguinte expressão:

$$
\begin{aligned}
& \quad E T r a d=c_{0}+c_{1} \cdot W \cdot R s \quad \ldots \ldots \ldots \ldots \ldots . .(5) \quad, \text { onde: } \\
& c l=a_{0}+a_{1} \cdot U R+a_{2} \cdot U d+a_{3} \cdot U R \cdot U d+a_{4} \cdot U R^{2}+a_{5} \cdot U d^{2} \ldots \ldots \ldots \ldots . .(6), \text { sendo: } \\
& c_{0}=\quad-0,3 \mathrm{~mm} \cdot \mathrm{dia}^{-1} \\
& \mathrm{a}_{0}=\quad 1,0656 \\
& \mathrm{a}_{1}=\quad-0,0012795 \\
& \mathrm{a}_{2}=\quad 0,044953 \\
& \mathrm{a}_{3}=\quad-0,00020033 \\
& \mathrm{a}_{4}=\quad-0,000031508 \\
& \mathrm{a}_{5}=\quad-0,0011026
\end{aligned}
$$

\subsubsection{Método de Jensen-Haise}

Segundo Jensen \& Haise (1963), evapotranspiração potencial é aquela que ocorre em campos irrigados em áreas áridas e semiáridas. Neste caso, é preferível chamá-la de ETc, pois na não há necessidade de área tampão homogênea, limitada e bem suprida de água, conforme definição de Evapotranspiração potencial.

Trabalhando em regiões semi-áridas americanas, os autores propuseram a seguinte equação, para estimativas em períodos entre 5 e 10 dias:

\footnotetext{
${ }^{4}$ Frevert, K.K; Asce, M.; Hill, W.; Braaten, B.C. Estimation of Fao Evapotranspiration Coeficients. Journal of Irrigation and Drainage Engineering, v.109, n.2, p.265-71, 1983.
} 


$$
\mathrm{ETjh}=\mathrm{Rs} \cdot(0,0252 \cdot \mathrm{T}+0,078)
$$

\subsubsection{Método de Linacre}

Para a estimativa da evapotranspiração mensal média $(\mathrm{mm} /$ dia $)$ de uma vegetação bem suprida de umidade, Linacre (1977), propôs a seguinte equação:

$$
\begin{gathered}
\text { ETlin }=\{[500 \cdot(\mathrm{T}+0,006) /(100-\Theta)]+15 \cdot(\mathrm{T}-\mathrm{To})\} /(80-\mathrm{T}) \\
\text { To }=\left[237,3 \cdot \operatorname{LOG}\left(\frac{\text { ea }}{\mathrm{A}}\right)\right] /\left[7,5-\mathrm{LOG}\left(\frac{\text { ea }}{\mathrm{A}}\right)\right] \ldots \ldots \ldots
\end{gathered}
$$

\subsubsection{7, Método de Hargreaves - Samani}

Usando dados obtidos no lisímetro de Davis, Califórnia, com gramado, Hargreaves \& Samani (1985) propuseram a seguinte equação para estimativa de ETo diária $(\mathrm{mm} / \mathrm{dia})$ :

$$
\text { ETh\& sam }=0,0023 \cdot \text { Qo } \cdot(\operatorname{Tmax}-\mathrm{Tmin})^{0,5} \cdot(\mathrm{T}+17,8)
$$

Neste trabalho, optou-se por substituir o termo Qo.(Tmax-Tmin) $)^{0,5}$ pela medida da radiação solar global diária, em mm.dia-1

3.6.4.8. Método de Penman (Penman, 1948) 
Esse método, chamado de método combinado, associa os efeitos do balanço de energia com aqueles do poder evaporante do ar. $\mathrm{O}$ método de Penman foi o primeiro dessa categoria, sendo considerado por muitos como padrão. Os demais métodos combinados são aproximações e extensões de Penman. Isso não significa que o método seja operacionalmente perfeito e correto, mas apenas que ele é baseado em princípios fĩsicos (Pereira, 1994).

É calculado pelas seguintes equações:

$$
\begin{gathered}
\text { ETpen }=\left(\frac{\Delta}{\Delta+\gamma}\right): \mathrm{H}+\left(\frac{\gamma}{\gamma+\Delta}\right) \cdot \mathrm{Ea} \\
\Delta=\frac{4098 \cdot e_{s}}{(T+237,3)^{2}} \ldots \ldots . . . \\
\mathrm{e}_{\mathrm{s}}=\mathrm{A} \cdot 10^{[7,5 \cdot \mathrm{T} /(237,3+\mathrm{T})]}
\end{gathered}
$$

Para estimar a radiação líquida, utiliza-se a seguinte equação:

$$
R n=Q o \cdot\left(0,24+0,58 \cdot \frac{n}{N}\right) \cdot(1-\rho)-\sigma \cdot T^{4} \cdot\left(0,1+0,9 \cdot \frac{n}{N}\right) \cdot\left(0,56-0,09 \sqrt{e_{a}}\right)
$$

$$
\frac{\mathrm{n}}{\mathrm{N}}=\left(\frac{\mathrm{Qg}_{\mathrm{g}}}{\mathrm{Q}_{\mathrm{o}}}-\mathrm{a}\right) / \mathrm{b}
$$

A equação acima foi utilizada para obter a relação $\mathrm{n} / \mathrm{N}$ pela inexistência dos valores de brilho solar (n). 
Para o poder refletor da superfície $(\rho)$, ou albedo da cultura foi adotado um valor de $\rho=0,25$, por se tratar de cultura cultivada em estufa ${ }^{5}$.

O termo Qo.(0,24+0,58.n/N) foi substituído pela medida da radiação solar global, em mm.dia-1 ${ }^{-1}$ respeitando a equação do balanço de energia.

O termo aerodinâmico foi calculado através da eq. (16):

$$
\begin{aligned}
& E a=(0,35+0,184 \cdot U d) \cdot\left(e_{s}-e_{a}\right) \\
& \mathrm{ea}=\left(\frac{\mathrm{UR}}{100}\right) \cdot \mathrm{es}
\end{aligned}
$$

\subsubsection{Método de Penman Piche}

Trata-se de uma simplificação do método de Penman, introduzindo a medida do poder evaporante do ar $\mathrm{Pi}(\mathrm{mm} / \mathrm{dia})$, obtido a partir de um evaporímetro de Piche. Segundo Villa Nova \& Ometto (1981), a Evapotranspiração é calculada pela fórmula:

$$
\text { ETps }=\frac{\Delta}{\Delta+\gamma} \cdot\left[Q o \cdot\left(0,24+0,58 \cdot \frac{n}{N}\right)\right]+0,28 \cdot P i
$$

3.6.5. Método de Estimativa da evapotranspiração da cultura

\subsubsection{Método de Penman-Monteith}

${ }^{5}$ PEREIRA, A.R. (Departamento de Física e Meteorologia, ESALQ/USP) Comunicação pessoal, 1996 
Esse método é uma adaptação do modelo original de Penman, introduzindo os conceitos de resistência do dossel $\left(r_{c}\right)$ e de resistência aerodinâmica $\left(r_{a}\right)$ (MONTEITH, 1965). O cálculo da evapotranspiração segue os seguintes passos:

$$
\text { ETpm = ETrad }+ \text { ETaero }
$$

O termo energético foi obtido pela equação 20 :

$$
\mathrm{ETrad}=0,408 \cdot \frac{\Delta}{\Delta+\gamma \cdot\left[1+\left(\frac{\mathrm{r}_{\mathrm{c}}}{\mathrm{r}_{\mathrm{a}}}\right)\right]} \cdot \mathrm{Rn}
$$

A resistência do dossel, s.m-1 , foi calculada pela seguinte equação (ALLEN, 1986):

$$
r_{c}=\frac{500-0,85 \cdot R n}{I A F}
$$

A resistência aerodinâmica, s.m-1, foi calculada através da equação (22):

$$
r_{a}=\frac{208}{U d}
$$

O termo aerodinâmico da equação de Penman-Monteith foi obtido pela equação (23):

$$
\text { ETaero }=187340,4 \cdot \frac{\gamma}{\Delta+\gamma \cdot\left[1+\frac{\mathrm{r}_{\mathrm{c}}}{\mathrm{r}_{\mathrm{a}}}\right]} \cdot \frac{\left[\mathrm{e}_{\mathrm{s}}-\mathrm{e}_{\mathrm{a}}\right]}{\mathrm{r}_{\mathrm{a}} \cdot(\mathrm{T}+275)}
$$




\section{RESULTADOS E DISCUSSÃO}

\subsection{Variação dos elementos meteorológicos internos e externos à estufa}

O cultivo em estufa modifica alguns elementos meteorológicos, como a temperatura, umidade relativa, radiação, etc, devido às suas características típicas, como a cobertura com material plástico e uso de sombrite, que implicam em diminuição dos ventos e ausência total de precipitação natural.

Nas Tabelas 9, 10, 11 e 12 são apresentados os elementos climáticos monitorados no interior e externamente à estufa plástica, no período considerado do estudo, de 15 de setembro a 05 de dezembro de 1995.

A seguir, serão discutidas as modificações causadas pelo cultivo em estufa, quando comparado com o ambiente externo.

\subsubsection{Radiação Solar Global}

Na Figura 13, são apresentados totais diários de radiação solar global observados no período de 27 de outubro a 05 de dezembro de 1995, no interior e fora da estufa com cobertura plástica. Nota-se que a radiação solar sofre atenuação ao atravessar a lâmina plástica, resultando em valores menores dentro da estufa. Foram verificadas diferenças de 10 até $50 \%$ entre as medidas externas e internas. 
Tabela 9 - Elementos climáticos monitorados no interior da estufa (n/d= não disponível)

\begin{tabular}{|c|c|c|c|c|c|c|c|c|c|}
\hline \multirow[t]{2}{*}{ Dia } & \multicolumn{3}{|c|}{ Temperatura interna $\left({ }^{\circ} \mathrm{C}\right)$} & \multicolumn{3}{|c|}{ Umidade relativa (\%) } & \multirow{2}{*}{$\frac{\text { Radiação }}{\left(\mathbf{M J} / \mathrm{m}^{2} / \text { dia }\right)}$} & \multirow{2}{*}{$\frac{\text { ET }}{(\mathrm{mm})}$} & \multirow{2}{*}{$\frac{\text { Piche }}{(\text { mm })}$} \\
\hline & média & máxima & minima & média & máximạ & mínima & & & \\
\hline $15 /$ set & 23,01 & 32,42 & 14,55 & 72,91 & 88,04 & 56,81 & 9,54 & 1,71 & 3,0 \\
\hline $16 /$ set & 24,62 & 31,87 & 16,47 & 65,87 & 92,96 & 38,49 & 11,81 & 1,70 & $\mathrm{n} / \mathrm{d}$ \\
\hline $17 /$ set & 20,11 & 27,76 & 14,62 & 85,37 & 93,59 & 65,73 & 6,21 & $\mathrm{n} / \mathrm{d}$ & $\mathrm{n} / \mathrm{d}$ \\
\hline $18 /$ set & 24,22 & 34,81 & 19,00 & 71,21 & 90,51 & 37,51 & 10,22 & $\mathrm{n} / \mathrm{d}$ & 3,7 \\
\hline 19/set & 23,73 & 32,88 & 18,24 & 75,47 & 91,78 & 43,76 & 8,97 & 1,05 & $\mathrm{n} / \mathrm{d}$ \\
\hline $20 /$ set & 17,66 & 21,14 & 16,21 & 85,52 & 93,47 & 72,69 & 3,23 & $\mathrm{n} / \mathrm{d}$ & $\mathrm{n} / \mathrm{d}$ \\
\hline $21 /$ set & 17,26 & 20,94 & 15,56 & 80,93 & 86,49 & 58,37 & 9,28 & 1,39 & 1,9 \\
\hline $22 /$ set & 22,28 & 33,83 & 13,83 & 72,27 & 91,25 & 42,04 & 13,15 & 1,95 & 3,6 \\
\hline $23 /$ set & 21,64 & 31,71 & 16,87 & 78,44 & 92,12 & 54,17 & 7,97 & 1,44 & 1,0 \\
\hline $24 /$ set & 21,53 & 32,38 & 18,33 & 84,96 & 93,28 & 58,91 & 6,22 & 0,91 & 1,2 \\
\hline $25 /$ set & 23,47 & 32,70 & 17,61 & 75,88 & 93,21 & 52,24 & 13,24 & 1,98 & 2,8 \\
\hline $26 /$ set & 22,44 & 34,77 & 16,41 & 78,65 & 94,50 & 37,20 & 9,33 & 1,83 & 2,9 \\
\hline $27 /$ set & 23,27 & 29,83 & 19,31 & 78,39 & 93,38 & 57,38 & 4,46 & $\mathrm{n} / \mathrm{d}$ & 1,6 \\
\hline $28 /$ set & 19,52 & 22,93 & 17,72 & 85,55 & 92,38 & 64,90 & 2,37 & $\mathrm{n} / \mathrm{d}$ & 1,8 \\
\hline $29 /$ set & 22,19 & 32,14 & 16,81 & 79,84 & 93,19 & 57,04 & 8,30 & 1,73 & 2,6 \\
\hline $30 /$ set & 25,04 & 35,40 & 17,40 & 75,44 & 92,93 & 49,78 & 14,35 & 2,43 & 2,1 \\
\hline $01 /$ out & 25,18 & 35,15 & 18,12 & 75,56 & 93,31 & 46,54 & 12,74 & 1,76 & 2,4 \\
\hline 02/out & 25,72 & 36,20 & 17,86 & 73,99 & 93,54 & 43,49 & 14,30 & 2,55 & 3,2 \\
\hline 03/out & 24,48 & 34,93 & 17,30 & 70,51 & 92,44 & 46,80 & 15,57 & $\mathrm{n} / \mathrm{d}$ & $\mathrm{n} / \mathrm{d}$ \\
\hline 04/out & 25,19 & 37,59 & 15,75 & 70,62 & 92,56 & 37,53 & 15,50 & 2,77 & 4,3 \\
\hline 05/out & 27,38 & 34,63 & 20,10 & 73,92 & 93,38 & 49,13 & 9,15 & $\mathrm{n} / \mathrm{d}$ & 3,1 \\
\hline 06/out & 22,05 & 27,05 & 18,86 & 81,33 & 91,27 & 63,29 & 5,30 & $\mathrm{n} / \mathrm{d}$ & 2,0 \\
\hline 07/out & 24,82 & 35,16 & 16,81 & 74,21 & 94,89 & 35,36 & 10,92 & 2,22 & 3,4 \\
\hline 08/out & 26,11 & 35,73 & 19,20 & 71,16 & 92,33 & 38,08 & $\mathrm{n} / \mathrm{d}$ & 2,40 & 2,9 \\
\hline 09/out & 24,73 & 31,06 & 19,85 & 75,72 & 91,89 & 44,40 & 7,70 & $\mathrm{n} / \mathrm{d}$ & 2,6 \\
\hline 10/out & 23,93 & 33,06 & 17,06 & 72,38 & 93,93 & 26,01 & 11,32 & 2,05 & 3,3 \\
\hline 11/out & 22,73 & 33,83 & 14,02 & 69,09 & 96,22 & 18,05 & 13,11 & 2,68 & 3,4 \\
\hline 12/out & 23,95 & 35,73 & 13,09 & 61,38 & 93,70 & 20,36 & 12,30 & 2,44 & 4,8 \\
\hline 13/out & 23,46 & 31,12 & 20,09 & 78,67 & 93,75 & 46,96 & 4,73 & 1,11 & 1,8 \\
\hline 14/out & 22,04 & 25,93 & 20,23 & 89,28 & 96,36 & 72,80 & 4,22 & 0,89 & 0,8 \\
\hline 15/out & 22,21 & 26,75 & 20,51 & 90,51 & 94,71 & 75,92 & 2,17 & 0,97 & 0,4 \\
\hline 16/out & 20,14 & 22,65 & 18,86 & 92,60 & 95,39 & 84,61 & 1,97 & $\mathrm{n} / \mathrm{d}$ & 0,4 \\
\hline 17/out & 18,28 & 21,05 & 15,61 & 93,11 & 95,34 & 87,20 & 1,47 & 0,73 & 0,2 \\
\hline 18/out & 23,14 & 33,16 & 13,49 & 80,11 & 97,37 & 45,32 & 14,79 & 2,01 & 2,2 \\
\hline 19/out & 23,50 & 34,76 & 18,93 & 79,74 & 94,84 & 45,05 & 11,52 & 2,12 & 2,3 \\
\hline 20/out & 20,69 & 32,62 & 16,27 & 85,43 & 96,73 & 49,95 & 7,70 & 1,75 & 1,3 \\
\hline 21/out & 20,48 & 26,68 & 16,99 & 84,50 & 94,54 & 60,77 & 6,16 & 2,70 & 1,2 \\
\hline 22/out & 20,79 & 30,53 & 13,95 & 75,01 & 96,49 & 37,29 & 16,96 & 2,00 & 3,2 \\
\hline 23/out & 21,13 & 31,37 & 12,24 & 70,25 & 96,19 & 29,00 & 17,78 & 3,29 & 3,6 \\
\hline 24/out & 23,58 & 34,89 & 13,56 & 65,11 & 96,77 & 22,82 & 16,84 & 3,37 & 4,0 \\
\hline 25/out & 25,39 & 37,24 & 15,48 & 68,13 & 91,23 & 23,15 & 16,53 & 3,34 & 4,2 \\
\hline 26/out & 26,42 & 37,58 & 17,26 & 59,30 & 88,06 & 22,55 & 15,81 & 2,34 & 5,1 \\
\hline
\end{tabular}


Tabela 10 - Continuação dos elementos climáticos internos

\begin{tabular}{|c|c|c|c|c|c|c|c|c|c|}
\hline \multirow[t]{2}{*}{ Dia } & \multicolumn{3}{|c|}{ Temperatura interna $\left({ }^{\circ} \mathrm{C}\right)$} & \multicolumn{3}{|c|}{ Umidade relativa (\%) } & \multirow{2}{*}{$\frac{\text { Radiação }}{\left(\mathrm{MJ} / \mathrm{m}^{2} / \mathrm{dia}\right)}$} & \multirow{2}{*}{$\frac{\mathrm{ET}}{(\mathbf{m m})}$} & \multirow{2}{*}{$\frac{\text { Piche }}{(\mathrm{mm})}$} \\
\hline & média & máxima & minima & média & máxima & minima & & & \\
\hline 27/out & 27,00 & 37,46 & 18,00 & 55,83 & 86,13 & 26,81 & 13,36 & 3,46 & 3,7 \\
\hline 28/out & 22,96 & 28,39 & 17,99 & 82,47 & 92,71 & 58,38 & 3,07 & 0,88 & 1,6 \\
\hline 29/out & 19,59 & 24,22 & 16,08 & 76,88 & 88,36 & 62,18 & 3,43 & 1,17 & 1,4 \\
\hline 30/out & 16,60 & 20,40 & 14,88 & 81,00 & 89,16 & 69,74 & $\mathrm{n} / \mathrm{d}$ & $\mathrm{n} / \mathrm{d}$ & 1,9 \\
\hline 31/out & 19,33 & 26,76 & 14,75 & 78,46 & 92,68 & 53,87 & 6,78 & $\mathrm{n} / \mathrm{d}$ & 1,6 \\
\hline $01 /$ nov & 21,31 & 33,92 & 14,41 & 78,88 & 94,34 & 38,03 & 11,44 & 1,97 & 2,6 \\
\hline $02 /$ nov & 22,48 & 35,03 & 16,52 & 75,79 & 93,34 & 32,30 & 16,07 & 3,68 & 3,2 \\
\hline 03/nov & 23,50 & 33,76 & 16,14 & 71,75 & 95,07 & 39,08 & 15,50 & 2,28 & 3,8 \\
\hline $04 /$ nov & 22,88 & 32,16 & 18,19 & 78,70 & 92,85 & 44,49 & 8,30 & 2,24 & 2,5 \\
\hline $05 /$ nov & 25,08 & 36,86 & 16,68 & 69,16 & 95,07 & 32,97 & 14,03 & 3,82 & 3,8 \\
\hline $06 /$ nov & 26,50 & 37,23 & 17,32 & 65,14 & 90,53 & 32,03 & 17,97 & 4,97 & $\mathrm{n} / \mathrm{d}$ \\
\hline $07 /$ nov & 28,31 & 39,34 & 18,39 & 59,97 & 88,92 & 27,91 & 18,34 & 3,53 & 6,1 \\
\hline $08 / \mathrm{nov}$ & 29,33 & 40,11 & 20,83 & 65,17 & 87,17 & 27,17 & 18,60 & $\mathrm{n} / \mathrm{d}$ & 6,0 \\
\hline 09/nov & 28,35 & 38,10 & 21,40 & 60,19 & 90,36 & 29,77 & 17,75 & 5,22 & 5,1 \\
\hline $10 /$ nov & 28,49 & 38,19 & 22,13 & 56,86 & 79,50 & 26,40 & 14,63 & 4,00 & 5,3 \\
\hline $11 /$ nov & 26,41 & 36,00 & 21,09 & 78,21 & 93,09 & 41,92 & 10,99 & 4,46 & 2,6 \\
\hline $12 / \mathrm{nov}$ & 23,31 & 28,59 & 19,17 & 84,94 & 94,04 & 59,18 & 4,39 & 1,66 & 1,2 \\
\hline 13/nov & 22,74 & 29,92 & 18,25 & 82,39 & 92,57 & 58,71 & 7,03 & 2,72 & $\overline{1,4}$ \\
\hline $14 /$ nov & 22,09 & 27,79 & 18,25 & 85,58 & 95,17 & 66,00 & 6,78 & 1,53 & 2,3 \\
\hline $15 / \mathrm{nov}$ & 24,33 & 32,18 & 20,16 & 80,93 & 92,19 & 53,60 & 9,56 & 1,79 & $\mathrm{n} / \mathrm{d}$ \\
\hline $16 /$ nov & 25,43 & 34,63 & 19,09 & 74,91 & 93,64 & 45,52 & 1,62 & 3,90 & $\mathrm{n} / \mathrm{d}$ \\
\hline $17 /$ nov & 26,35 & 36,60 & 18,70 & 69,51 & 95,91 & 36,28 & 1,85 & 3,21 & 2,7 \\
\hline $18 /$ nov & 24,44 & 35,63 & 17,64 & 78,71 & 92,88 & 44,26 & 1,10 & 2,89 & 2,5 \\
\hline 19/nov & 21,84 & 31,26 & 15,80 & 74,33 & 94,22 & 39,75 & 1,81 & 3,98 & - \\
\hline $20 /$ nov & 21,70 & 31,64 & 14,82 & 70,93 & 93,49 & 36,16 & 1,95 & 4,97 & - \\
\hline $21 / \mathrm{nov}$ & 22,66 & 34,21 & 14,42 & 68,82 & 93,09 & 31,57 & 2,10 & 4,46 & - \\
\hline $22 / \mathrm{nov}$ & 24,31 & 35,87 & 13,82 & 71,89 & 93,50 & 31,91 & 2,10 & 4,28 & - \\
\hline $23 / \mathrm{nov}$ & 23,08 & 33,57 & 16,86 & 80,28 & 94,44 & 40,28 & 1,36 & 2,62 & - \\
\hline $24 /$ nov & 24,30 & 33,74 & 20,11 & 80,98 & 94,90 & 50,90 & 1,35 & 2,22 & - \\
\hline $25 / \mathrm{nov}$ & 25,98 & 38,85 & 17,68 & 77,22 & 94,65 & 42,32 & 1,97 & 5,40 & - \\
\hline $26 /$ nov & 27,47 & 37,99 & 18,25 & 69,79 & 95,86 & 32,03 & 2,05 & 4,52 & - \\
\hline $27 /$ nov & 27,37 & 36,71 & 19,45 & 66,98 & 91,79 & 34,15 & 1,96 & 3,92 & - \\
\hline $28 / \mathrm{nov}$ & 24,20 & 33,48 & 18,13 & 80,18 & 94,18 & 50,49 & 1,24 & $\mathrm{n} / \mathrm{d}$ & - \\
\hline $29 /$ nov & 25,52 & 38,85 & 16,54 & 74,95 & 96,80 & 31,04 & 2,21 & 3,64 & - \\
\hline $30 /$ nov & 25,81 & 36,73 & 17,34 & 69,03 & 95,21 & 28,06 & 1,90 & $n / d$ & - \\
\hline $01 / \mathrm{dez}$ & 26,94 & 37,91 & 18,59 & 68,14 & 92,86 & 34,09 & 2,02 & $\mathrm{n} / \mathrm{d}$ & - \\
\hline $02 / \mathrm{dez}$ & 27,87 & 42,16 & 18,93 & 67,33 & 91,66 & 28,32 & 1,99 & 5,33 & - \\
\hline 03/dez & 27,20 & 38,43 & 17,39 & 61,33 & 88,49 & 25,00 & 2,03 & 4,01 & - \\
\hline $04 / \mathrm{dez}$ & 25,65 & 35,23 & 20,56 & 72,90 & 90,22 & 40,08 & 1,40 & 3,18 & - \\
\hline $05 / \mathrm{dez}$ & 25,52 & 35,61 & 18,66 & 70,49 & 93,79 & 35,49 & 1,80 & $\mathrm{n} / \mathrm{d}$ & - \\
\hline
\end{tabular}


Tabela 11 - Elementos climáticos monitorados no exterior da estufa (n/d= não disponível)

\begin{tabular}{|c|c|c|c|c|c|c|c|c|c|c|}
\hline \multirow[t]{2}{*}{ Dia } & \multicolumn{3}{|c|}{$\begin{array}{l}\text { Temperatura externa } \\
\left({ }^{\circ} \mathrm{C}\right)\end{array}$} & \multicolumn{3}{|c|}{$\begin{array}{l}\text { Umidade relativa } \\
(\%)\end{array}$} & \multirow{2}{*}{$\begin{array}{l}\text { Radiação }(*) \\
\left(\mathrm{MJ} / \mathrm{m}^{*} / \text { dia }\right)\end{array}$} & \multicolumn{3}{|c|}{ Velocidade do vento $(\mathrm{m} / \mathrm{s})$} \\
\hline & média & máxima & minima & media & máxima & minima & & média & maxima & hora \\
\hline $15 /$ set & 21,66 & 29,28 & 13,49 & 66,10 & 85,19 & 44,42 & $\mathrm{n} / \mathrm{d}$ & 2,54 & $\mathrm{n} / \mathrm{d}$ & $\mathrm{n} / \mathrm{d}$ \\
\hline $16 /$ set & 22,25 & 28,84 & 14,45 & 51,91 & 88,66 & 23,73 & $\mathrm{n} / \mathrm{d}$ & 2,22 & $\mathrm{n} / \mathrm{d}$ & $\mathrm{n} / \mathrm{d}$ \\
\hline $17 /$ set & 18,56 & 26,95 & 13,16 & 82,58 & 93,10 & 54,28 & $\mathrm{n} / \mathrm{d}$ & 1,42 & $\mathrm{n} / \mathrm{d}$ & $\mathrm{n} / \mathrm{d}$ \\
\hline $18 /$ set & 23,14 & 32,85 & 19,07 & 69,62 & 94,62 & 35,65 & $\mathrm{n} / \mathrm{d}$ & 3,71 & $\mathrm{n} / \mathrm{d}$ & $\mathrm{n} / \mathrm{d}$ \\
\hline $19 /$ set & 22,11 & 29,16 & 16,99 & 78,43 & 100,00 & 45,38 & $\mathrm{n} / \mathrm{d}$ & 2,30 & $\mathrm{n} / \mathrm{d}$ & $\mathrm{n} / \mathrm{d}$ \\
\hline $20 /$ set & 15,51 & 17,69 & 13,66 & 81,72 & 92,84 & 71,40 & $\mathrm{n} / \mathrm{d}$ & 2,88 & $\mathrm{n} / \mathrm{d}$ & $\mathrm{n} / \mathrm{d}$ \\
\hline $21 /$ set & 16,45 & 19,36 & 14,53 & 79,25 & 93,68 & 58,74 & $\mathrm{n} / \mathrm{d}$ & 2,11 & 8,13 & $16: 28$ \\
\hline 22/set & 20,70 & 30,40 & 13,30 & 67,98 & 93,38 & 36,76 & $\mathrm{n} / \mathrm{d}$ & 1,21 & 6,96 & $17: 28$ \\
\hline $23 /$ set & 20,05 & 26,65 & 16,77 & 72,75 & 95,60 & 49,76 & $\mathrm{n} / \mathrm{d}$ & 2,42 & 8,33 & $15: 28$ \\
\hline $24 /$ set & 19,26 & 26,39 & 16,82 & 90,22 & 100,00 & 61,42 & $\mathrm{n} / \mathrm{d}$ & 2,34 & 7,94 & $18: 16$ \\
\hline $25 /$ set & 21,18 & 28,01 & 16,45 & 76,60 & 100,00 & 46,73 & $\mathrm{n} / \mathrm{d}$ & 1,41 & $\mathrm{n} / \mathrm{d}$ & $\mathrm{n} / \mathrm{d}$ \\
\hline $26 /$ set & 20,91 & 32,45 & 14,82 & 79,62 & 100,00 & 35,88 & $\mathrm{n} / \mathrm{d}$ & 2,52 & 12,84 & $15: 11$ \\
\hline $27 /$ set & 21,91 & 26,69 & 18,36 & 78,44 & 98,71 & 57,53 & $\mathrm{n} / \mathrm{d}$ & 2,15 & 6,08 & $16: 51$ \\
\hline $28 /$ set & 18,53 & 21,65 & 16,53 & 90,62 & 99,76 & 63,24 & $\mathrm{n} / \mathrm{d}$ & 2,57 & 8,23 & $17: 52$ \\
\hline $29 /$ set & 20,12 & 27,06 & 15,71 & 85,97 & 100,00 & 60,10 & $\mathrm{n} / \mathrm{d}$ & 1,81 & 5,88 & $16: 00$ \\
\hline $30 /$ set & 22,81 & 31,77 & 16,31 & 76,83 & 100,00 & 45,50 & $\mathrm{n} / \mathrm{d}$ & 1,36 & 7,94 & $18: 45$ \\
\hline 01 /out & 23,08 & 32,13 & 17,00 & 78,02 & 100,00 & 44,00 & $\mathrm{n} / \mathrm{d}$ & 1,44 & 9,02 & $16: 28$ \\
\hline 02/out & 23,82 & 31,98 & 17,01 & 70,09 & 100,00 & 35,00 & $\mathrm{n} / \mathrm{d}$ & 1,57 & 6,96 & $14: 25$ \\
\hline 03/out & 22,27 & 30,58 & 16,04 & 68,90 & 94,91 & 43,27 & $\mathrm{n} / \mathrm{d}$ & 1,83 & 8,62 & $15: 45$ \\
\hline 04/out & 22,84 & 33,37 & 14,69 & 67,79 & 96,30 & 31,10 & $\mathrm{n} / \mathrm{d}$ & 1,97 & 8,82 & 19:55 \\
\hline 05/out & 25,64 & 30,31 & 19,15 & 72,55 & 98,66 & 42,94 & $\mathrm{n} / \mathrm{d}$ & 2,75 & 7,84 & $13: 38$ \\
\hline 06/out & 21,26 & 24,57 & 17,84 & 82,66 & 98,23 & 67,13 & $\mathrm{n} / \mathrm{d}$ & 1,25 & 4,21 & $16: 12$ \\
\hline $07 /$ out & 23,02 & 31,55 & 15,72 & 75,62 & 100,00 & 38,32 & $\mathrm{n} / \mathrm{d}$ & 1,50 & 6,76 & $18: 49$ \\
\hline 08/out & 24,72 & 32,74 & 18,28 & 66,96 & 100,00 & 33,18 & $\mathrm{n} / \mathrm{d}$ & 1,84 & 7,55 & $12: 39$ \\
\hline 09/out & 23,03 & 28,06 & 19,06 & 74,73 & 94,56 & 51,27 & $\mathrm{n} / \mathrm{d}$ & 2,15 & 9,51 & $15: 35$ \\
\hline 10/out & 22,49 & 29,14 & 16,60 & 65,80 & 100,00 & 25,95 & $\mathrm{n} / \mathrm{d}$ & 2,00 & 10,68 & $13: 46$ \\
\hline 11/out & 20,98 & 29,43 & 13,33 & 63,07 & 100,00 & 16,06 & $\mathrm{n} / \mathrm{d}$ & 1,74 & 8,04 & $15: 42$ \\
\hline 12/out & 23,04 & 33,17 & 12,46 & 57,94 & 99,30 & 18,99 & $\mathrm{n} / \mathrm{d}$ & 1,05 & 7,45 & $12: 33$ \\
\hline 13/out & 22,53 & 29,90 & 18,41 & 83,78 & 100,00 & 49,44 & $\mathrm{n} / \mathrm{d}$ & 3,02 & 16,95 & 19:16 \\
\hline 14/out & 20,73 & 24,11 & 18,82 & 97,45 & 100,00 & 75,66 & $\mathrm{n} / \mathrm{d}$ & 1,92 & 7,55 & $12: 53$ \\
\hline $15 /$ out & 20,02 & 22,67 & 19,08 & 94,72 & 100,00 & 90,85 & $\mathrm{n} / \mathrm{d}$ & 0,86 & 4,41 & 19:06 \\
\hline 16/out & 18,69 & 20,13 & 17,73 & 96,26 & 100,00 & 94,03 & $\mathrm{n} / \mathrm{d}$ & 1,77 & 7,06 & $11: 25$ \\
\hline 17 /out & 16,75 & 18,83 & 14,75 & 98,95 & 100,00 & 97,53 & $\mathrm{n} / \mathrm{d}$ & 1,30 & 11,66 & $15: 49$ \\
\hline 18/out & 20,08 & 27,78 & 11,97 & 85,32 & 100,00 & 53,22 & $\mathrm{n} / \mathrm{d}$ & 1,33 & 6,17 & $12: 42$ \\
\hline 19/out & 21,01 & 28,41 & 16,77 & 83,18 & 100,00 & 52,18 & $\mathrm{n} / \mathrm{d}$ & 1,71 & 7,35 & $16: 08$ \\
\hline 20/out & 18,74 & 28,00 & 14,75 & 95,68 & 100,00 & 57,34 & $\mathrm{n} / \mathrm{d}$ & 1,96 & 21,07 & $14: 05$ \\
\hline $21 /$ out & 18,64 & 23,03 & 15,17 & 92,77 . & 100,00 & 65,21 & $\mathrm{n} / \mathrm{d}$ & 1,19 & 5,88 & $23: 27$ \\
\hline 22/out & 17,79 & 24,45 & 12,79 & 74,86 & 100,00 & 38,67 & $\mathrm{n} / \mathrm{d}$ & 2,44 & 7,84 & $12: 40$ \\
\hline 23/out & 19,28 & 28,27 & 11,67 & 68,04 & 100,00 & 29,06 & $\mathrm{n} / \mathrm{d}$ & 1,33 & 6,47 & $12: 08$ \\
\hline $2+/$ out & 22,36 & 31,84 & 13,10 & 61,25 & 100,00 & 22,40 & $\mathrm{n} / \mathrm{d}$ & 1,19 & 6,37 & $13: 41$ \\
\hline $25 /$ out & 24,99 & 33,82 & 15,87 & 52,51 & 93,94 & 21,91 & $\mathrm{n} / \mathrm{d}$ & 1,49 & 7,15 & $8: 20$ \\
\hline 26/out & 26,54 & 34,32 & 18,67 & 46,34 & 75,40 & 23,60 & $\mathrm{n} / \mathrm{d}$ & 1,37 & 7,25 & $12: 39$ \\
\hline
\end{tabular}


Tabela 12 - Continuação dos elementos climáticos externos

\begin{tabular}{|c|c|c|c|c|c|c|c|c|c|c|}
\hline \multirow[t]{2}{*}{ Dia } & \multicolumn{3}{|c|}{ Temperatura externa $\left({ }^{\circ} \mathrm{C}\right)$} & \multicolumn{3}{|c|}{$\begin{array}{c}\text { Umidade relativa } \\
(\%)\end{array}$} & \multirow{2}{*}{$\begin{array}{l}\text { Radiação } \\
\left(\mathbf{M J} / \mathbf{m}^{2} / \text { dia }\right)\end{array}$} & \multicolumn{3}{|c|}{$\begin{array}{l}\text { Vélocidade do vento } \\
(\mathrm{m} / \mathrm{s})\end{array}$} \\
\hline & média & máxima & minima & média & máxima & mínima & & média & maxima & hora \\
\hline 27/out & 27,15 & 34,30 & 20,06 & 46,96 & 73,01 & 20,06 & 23,01 & 1,75 & 8,13 & $23: 53$ \\
\hline 28/out & 21,31 & 25,48 & 16,70 & 88,46 & 100,00 & 63,48 & 6,41 & 1,67 & 11,96 & $18: 46$ \\
\hline 29/out & 17,48 & 20,26 & 14,49 & 81,11 & 97,66 & 66,78 & 6,48 & 2,86 & 9,21 & $18: 29$ \\
\hline 30/out & 15,77 & 18,56 & 14,26 & 83,28 & 91,31 & 73,07 & $\mathrm{n} / \mathrm{d}$ & 2,19 & 9,51 & $17: 46$ \\
\hline 31 /out & 17,23 & 21,65 & 13,92 & 82,14 & 98,35 & 60,71 & 11,92 & 1,40 & 5,29 & $10: 03$ \\
\hline $01 /$ nov & 18,62 & 27,69 & 13,32 & 81,42 & 100,00 & 46,89 & 20,13 & 1,88 & 9,02 & $16: 10$ \\
\hline $02 /$ nov & 19,98 & 29,98 & 15,28 & 82,45 & 100,00 & 39,42 & 24,91 & 1,80 & 14,70 & $17: 16$ \\
\hline $03 /$ nov & 21,20 & 28,87 & 15,31 & 78,66 & 100,00 & 44,93 & 24,95 & 1,49 & 6,47 & 19:25 \\
\hline $04 /$ nov & 20,82 & 26,70 & 17,20 & 79,81 & 100,00 & 53,56 & 14,46 & 1,90 & 9,80 & $11: 54$ \\
\hline $05 /$ nov & 23,25 & 31,34 & 15,89 & 67,17 & 94,63 & 38,66 & 24,22 & 2,17 & 9,80 & 9:09 \\
\hline $06 /$ nov & 24,89 & 33,44 & 16,53 & 64,61 & 97,80 & 32,96 & 28,75 & 1,33 & 7,55 & $12: 42$ \\
\hline $07 /$ nov & 26,26 & 35,52 & 18,25 & 60,18 & 100,00 & 30,31 & 29,47 & 1,46 & 6,27 & $12: 01$ \\
\hline $08 /$ nov & 26,99 & 36,30 & 20,36 & 61,63 & 93,67 & 28,09 & 29,95 & 1,89 & 6,86 & $10: 51$ \\
\hline 09/nov & 27,48 & 34,31 & 21,20 & 56,67 & 90,70 & 31,27 & 28,54 & 1,71 & 7,74 & $11: 54$ \\
\hline $10 /$ nov & 27,46 & 34,93 & 21,75 & 54,55 & 85,66 & 26,29 & 23,24 & 2,19 & 11,07 & $19: 34$ \\
\hline $11 /$ nov & 24,03 & 31,41 & 19,61 & 84,27 & 100,00 & 49,75 & 18,09 & 2,03 & 8,33 & $2: 54$ \\
\hline $12 / \mathrm{nov}$ & 20,15 & 23,48 & 17,76 & 95,12 & 100,00 & 71,93 & 7,29 & 1,73 & 6,96 & $21: 10$ \\
\hline 13/nov & 20,43 & 25,11 & 17,10 & 91,23 & 100,00 & 69,00 & 11,98 & 1,39 & 6,08 & 12:09 \\
\hline 14/nov & 20,30 & 25,40 & 17,00 & 96,73 & 100,00 & 68,87 & 11,79 & 1,89 & 9,70 & 10:40 \\
\hline $15 /$ nov & 21,96 & 27,86 & 18,39 & 91,58 & 100,00 & 62,33 & 14,78 & 1,85 & 7,55 & \begin{tabular}{|l|}
$8: 59$ \\
\end{tabular} \\
\hline $16 /$ nov & 23,65 & 28,77 & 18,00 & 76,50 & 100,00 & 48,91 & 25,53 & 1,24 & 6,66 & $16: 31$ \\
\hline 17/nov & 24,80 & 31,87 & 17,61 & 71,34 & 100,00 & 37,69 & 28,18 & 1,40 & 6,47 & $12: 38$ \\
\hline $18 /$ nov & 21,72 & 29,66 & 15,69 & 82,60 & 98,05 & 52,65 & 17,62 & 1,83 & 17,74 & $15: 15$ \\
\hline 19/nov & 19,75 & 26,79 & 14,29 & 73,19 & 98,04 & 43,67 & 27,97 & 1,94 & 7,74 & $12: 45$ \\
\hline $20 /$ nov & 19,41 & 26,75 & 13,56 & 70,65 & 98,58 & 41,08 & 29,36 & 2,20 & 8,04 & $8: 54$ \\
\hline $21 / \mathrm{nov}$ & 20,39 & 28,62 & 13,60 & 66,42 & 96,28 & 30,99 & 31,03 & 1,72 & 9,31 & $19: 08$ \\
\hline $22 /$ nov & 21,65 & 31,77 & 13,56 & 67,83 & 96,51 & 31,22 & 29,84 & 1,32 & 6,86 & $15: 26$ \\
\hline $23 /$ nov & 21,20 & 30,94 & 15,74 & 85,83 & 100,00 & 44,91 & 20,91 & 2,01 & 9,70 & \begin{tabular}{|l}
$14: 58$ \\
\end{tabular} \\
\hline $24 /$ nov & 22,22 & 28,48 & 18,59 & 89,80 & 100,00 & 56,87 & 19,73 & 1,66 & 6,47 & $13: 20$ \\
\hline $25 /$ nov & 22,03 & 28,98 & 15,83 & 83,41 & 100,00 & 49,79 & 28,64 & 1,91 & 7,45 & 18:14 \\
\hline 26/nov & 24,56 & 32,65 & 16,87 & 70,09 & 100,00 & 33,93 & 29,47 & 1,33 & 6,27 & $21: 09$ \\
\hline $27 /$ nov & 25,80 & 33,69 & 19,03 & 68,61 & 100,00 & 36,17 & 28,19 & 1,54 & 9,70 & $20: 19$ \\
\hline $28 /$ nov & 21,66 & 27,74 & 17,58 & 87,71 & 100,00 & 54,80 & 18,26 & 1,76 & 7,06 & $14: 50$ \\
\hline 29/nov & 22,52 & 30,58 & 15,35 & 68,85 & 99,38 & 31,42 & 31,43 & 1,44 & 5,98 & $16: 19$ \\
\hline $30 /$ nov & 23,75 & 32,37 & 16,43 & 66,72 & 100,00 & 27,25 & 27,53 & 1,15 & 7,06 & $14: 04$ \\
\hline $01 / \mathrm{dez}$ & 25,23 & 33,39 & 18,59 & 66,30 & 95,60 & 35,00 & 29,07 & 1,55 & 6,66 & $15: 19$ \\
\hline $02 / \mathrm{dez}$ & 26,13 & 34,22 & 19,06 & 53,94 & 85,60 & 18,50 & 28,92 & 1,62 & 7,15 & $13: 42$ \\
\hline $03 / \mathrm{dez}$ & 25,82 & 34,31 & 17,24 & 53,24 & 89,65 & 26,39 & 29,30 & 1,54 & 7,84 & $23: 01$ \\
\hline 04/dez & 23,55 & 29,80 & 19,14 & 73,47 & 96,97 & 45,05 & 20,14 & 1,65 & 6,96 & 19:13 \\
\hline $05 / \mathrm{dez}$ & 23,10 & 30,61 & 17,43 & 72,33 & 100,00 & 41,24 & 28,70 & 2,12 & 10,00 & $18: 36$ \\
\hline
\end{tabular}


Os dados não disponíveis de evapotranspiração da cultura medida pelo lisímetro foram consequência de problemas de drenagem do equipamento, sendo estas medidas descartadas. A série de dados não disponíveis de radiação solar global $\left(^{*}\right)$ foi em decorrência do atraso no fornecimento do sensor específico pela empresa colaboradora, no período inicial do experimento (de 15/09 até 26/10/96).

Para as condições do experimento, no período considerado, observou-se que, em média, $30 \%$ da radiação foi perdida por reflexão ou absorção, ou seja, $70 \%$ da radiação externa chegou até o dossel da cultura.

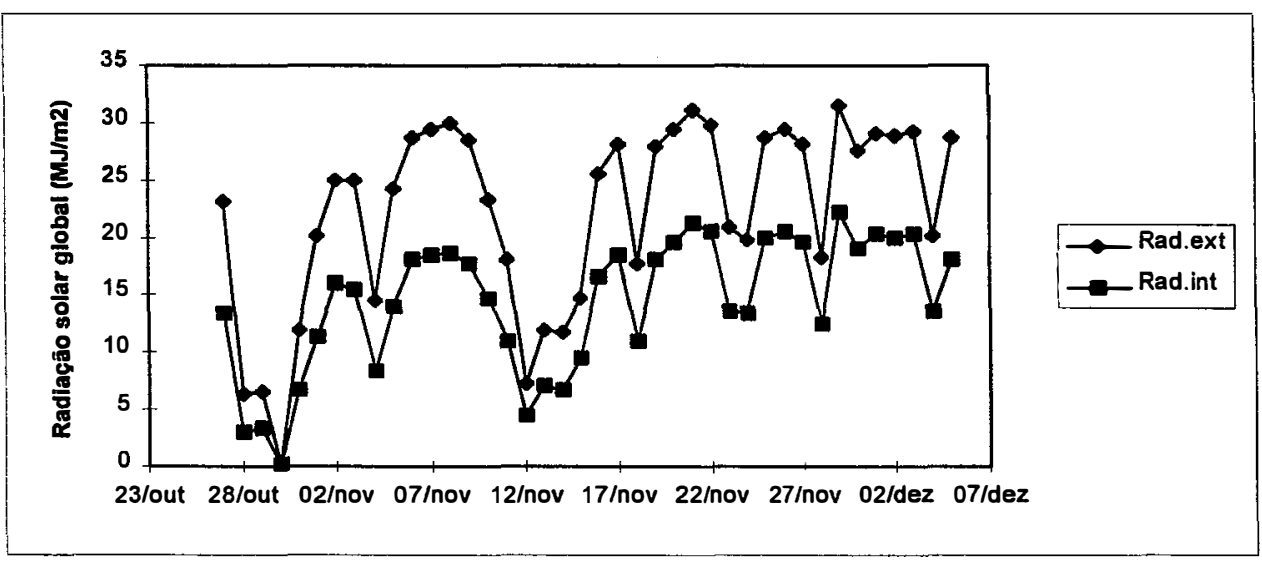

Figura 13 - Valores diários de radiação solar global obtidos no interior e fora da estufa.

$\mathrm{Na}$ Figura 14 pode ser observada a dispersão dos dados de radiação interna e externa, sendo obtido um alto índice de correlação $\left(R^{2}=97,79 \%\right)$ entre os valores medidos externos e internos.

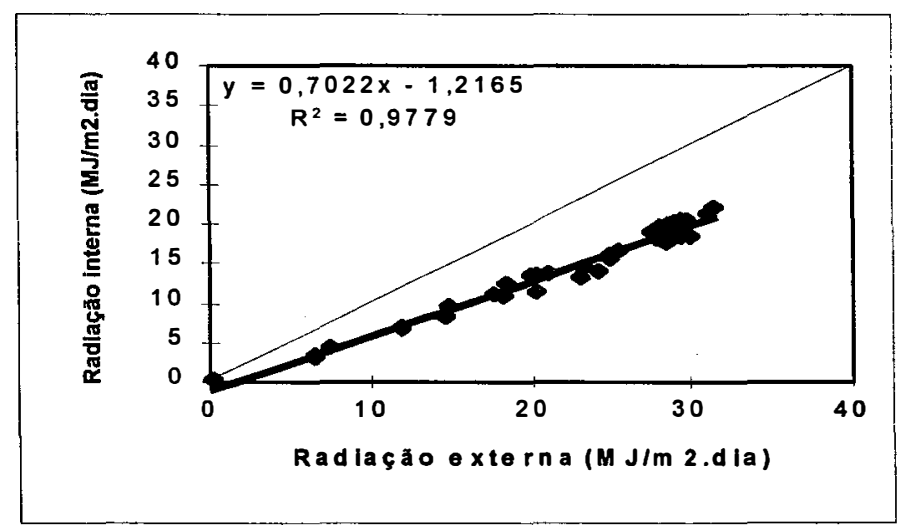

Figura 14 - Análise dos valores de radiação solar global externa x interna 
Analisando-se a equação $y=0,7022 . x-1,2165$, verifica-se que $30 \%$ da radiação incidente, em média, é retida pelo filme plástico. Este valor é bastante semelhante aos encontrados por Martin \& Robledo (1981), Robledo (1981) e Buriol et al. (1993).

Essa perda de transmissividade da ordem de $30 \%$ é um pouco elevada quando comparada com a faixa de 10 a $17 \%$ encontrada por Robledo (1987), que trabalhou com diversos tipos de plástico. Por outro lado, Farias et al. (1993), utilizando polietileno de baixa densidade, o mesmo utilizado neste trabalho, verificou uma redução de 10 a $35 \%$ na transmissividade no intervalo de 11 a 13 horas, concordando com os valores encontrados neste trabalho.

Comparando-se dois dias distintos, um deles com céu limpo (29/11/95) e outro com céu nublado (28/10/95), verificou-se uma diferença bastante significativa nos valores de radiação solar. No dia 29 de novembro os valores máximos de radiação solar global foram de 1091,2 e $939,1 \mathrm{~W} / \mathrm{m}^{2}$ fora e dentro da estufa, respectivamente, e no dia 28 de outubro a radiação solar teve valores máximos de 394,0 e 191,3 W/m² (Figuras 15 e 16).

Em resumo, uma redução no valor de radiação solar de $747,8 \mathrm{~W} / \mathrm{m}^{2}$ entre o dia de céu limpo e o dia nublado (equivalente a $80 \%$ ), ocasionou uma diminuição da evapotranspiração de $2,75 \mathrm{~mm}$, que corresponde a uma redução de $76 \%$.

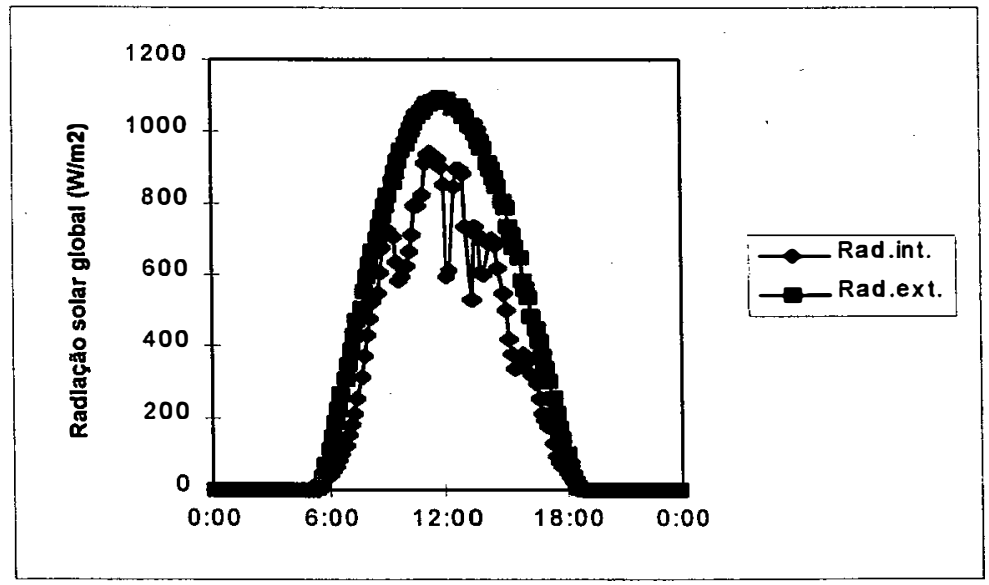

Figura 15 - Radiação solar global no dia 29/11/95 (céu limpo) 


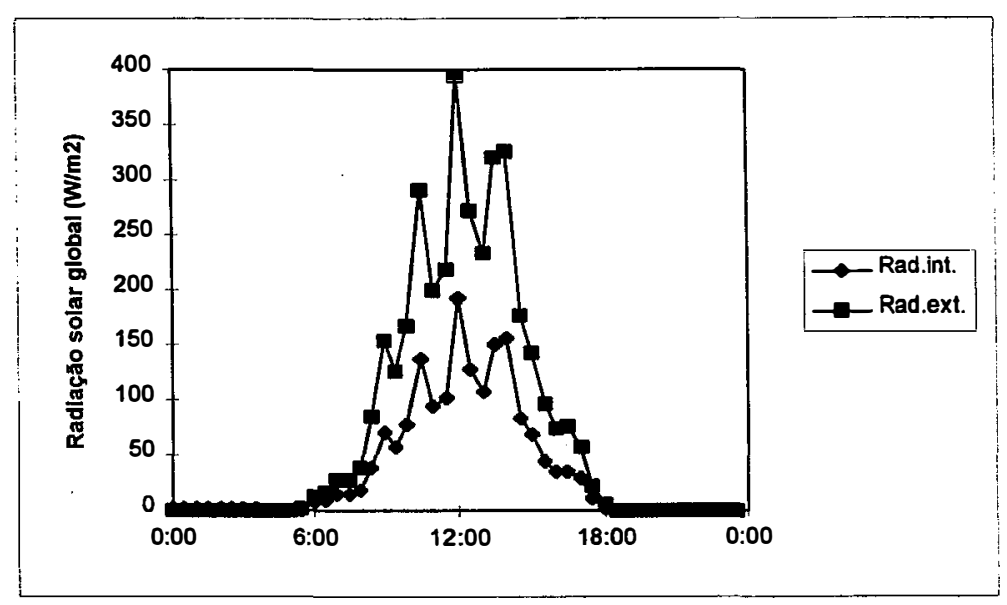

Figura 16 - Radiação solar global no dia 28/10/95 (dia nublado)

Essas diferenças influenciaram diretamente o processo evapotranspirativo, ocasionando uma evapotranspiração interna de $3.64 \mathrm{~mm} /$ dia no dia de céu limpo e 0.89 $\mathrm{mm} /$ dia com céu nublado, conforme medidas do lisímetro de pesagem com célula de carga, instalado dentro da estufa.

\subsubsection{Velocidade do vento}

A Figura 17 mostra as medidas de velocidade do vento no exterior da estufa, com uma média de $2 \mathrm{~m} / \mathrm{s}$ no período de 8 de outubro até 07 de dezembro de 1995 . 


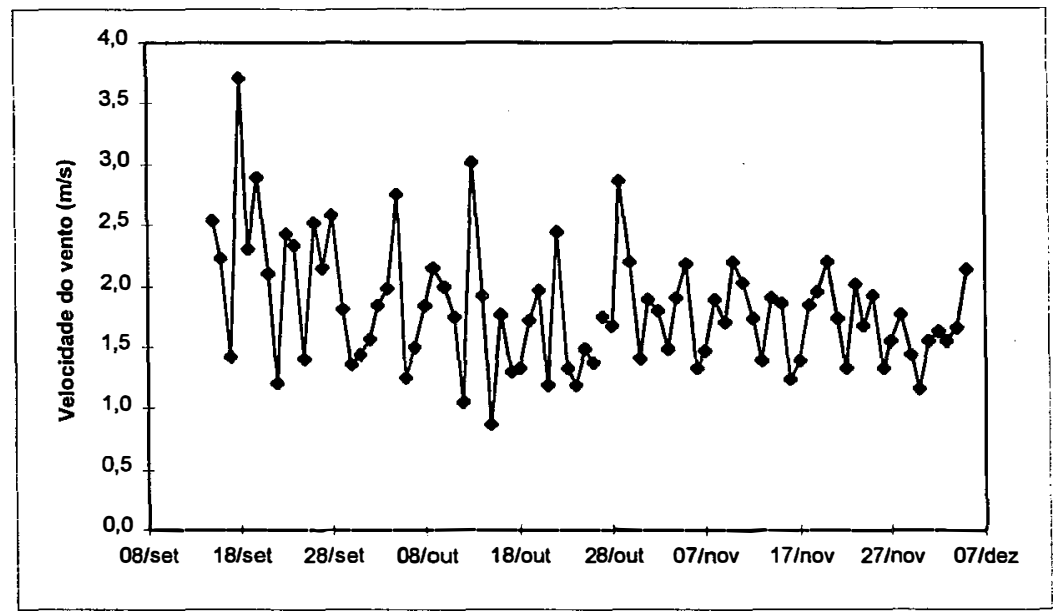

Figura 17 - Velocidade do vento $(\mathrm{m} / \mathrm{s})$, medida no exterior da estufa.

Com relação à velocidade máxima do vento, observaram-ser valores de até $21 \mathrm{~m} / \mathrm{s}$, como o ocorrido no dia 20 de outubro. (Figura 18)

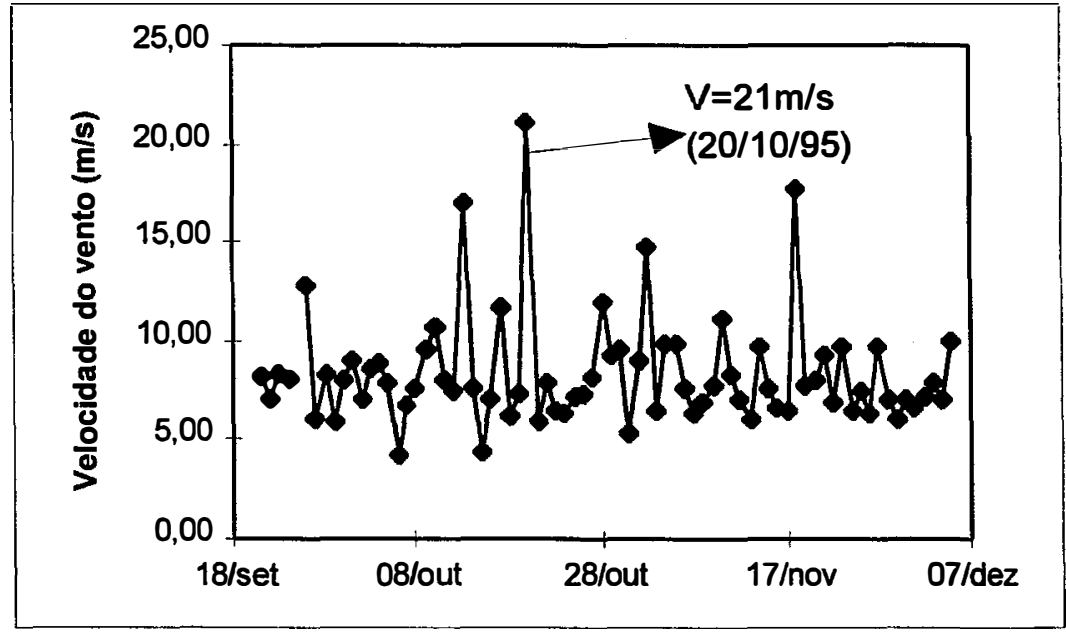

Figura 18 - Velocidade máxima do vento fora da estufa 


\subsubsection{Umidade relativa e temperatura do ar}

Em condições normais, a umidade relativa do ar tem comportamento contrário ao da temperatura do ar, ou seja, valores elevados no período noturno e baixos durante o diurno.

A Figura 19 mostra a variação diária da temperatura, da umidade relativa e da radiação no interior e fora da estufa, para o dia 27/10/95, que teve as seguintes médias para os parâmetros meteorológicos internos e externos: (Tabela 13 ).

Analisando-se a Figura 19, observa-se que a temperatura do ar e a umidade relativa apresentam comportamento semelhante, porém inverso. Como a capacidade do ambiente em reter umidade aumenta exponencialmente com o aumento da temperatura, supõe-se que a umidade relativa no interior da estufa devesse ser sempre menor que a externa. Porém a umidade relativa pode ser bastante influenciada pela evapotranspiração, que eleva a tensão de vapor d'água do ar e pela baixa taxa de renovação do ar no interior da estufa. 
Tabela 13 - Parâmetros meteorológicos internos e externos (dia 27/10/96)

\begin{tabular}{|l|c|c|}
\cline { 2 - 3 } \multicolumn{1}{c|}{} & ESTUFA & AMBIENTE \\
\hline Temperatura média $\left({ }^{\circ} \mathbf{C}\right)$ & 27,0 & 27,2 \\
\hline Temperatura máxima $\left({ }^{\circ} \mathbf{C}\right)$ & 37,5 & 34,3 \\
\hline Temperatura mínima $\left.\mathbf{~}^{\circ} \mathbf{C}\right)$ & 18,0 & 20,0 \\
\hline Umidade relativa média (\%) & 55,9 & 47,0 \\
\hline Velocidade do vento média (m/s) & & 1,8 \\
\hline Velocidade do vento máxima (m/s) & & 8,2 \\
\hline
\end{tabular}

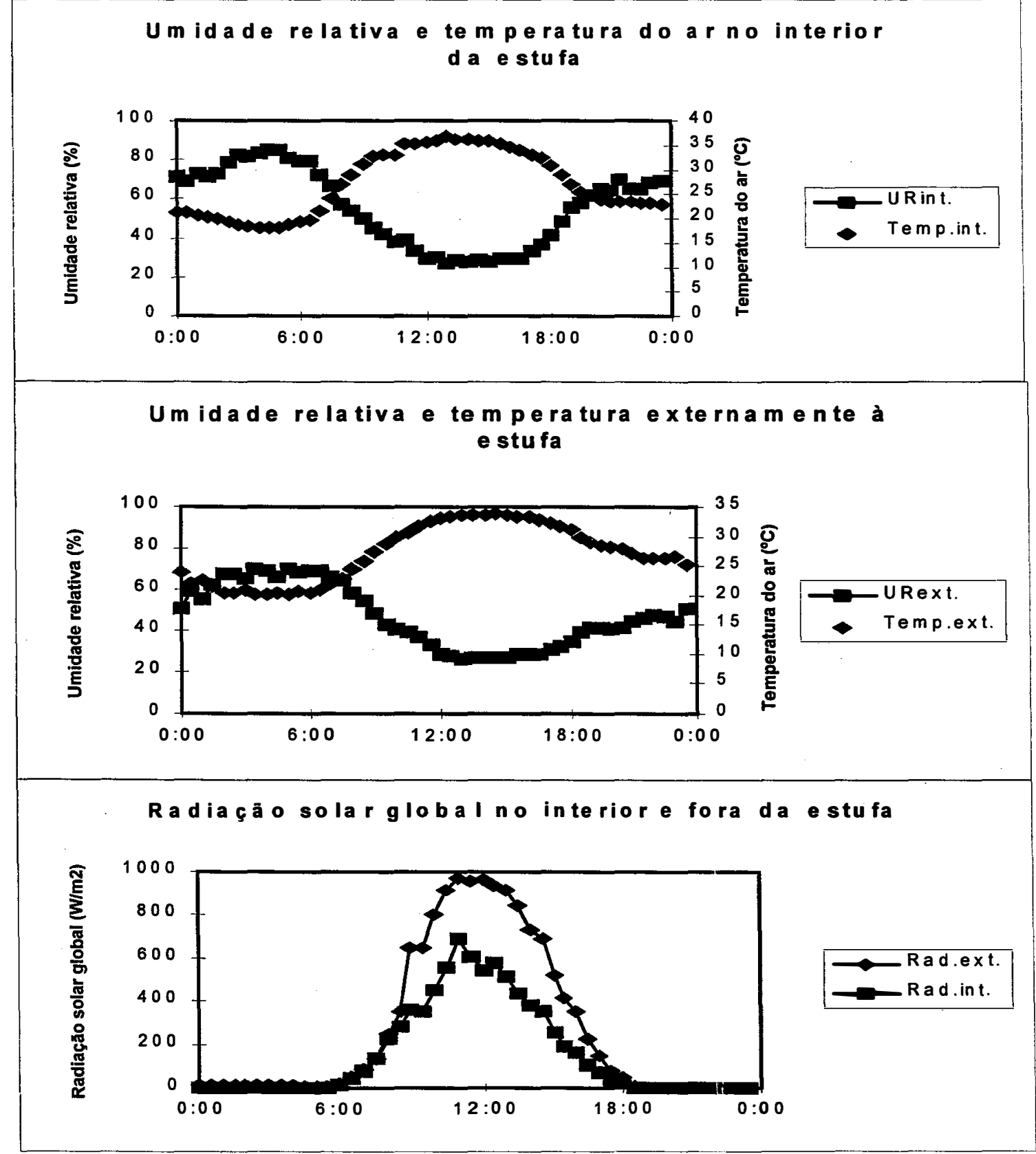

Figura 19 - Dados de temperatura, radiação global e umidade relativa (27/10/95) 
Para dias com umidade relativa média baixa, observou-se que os valores medidos no interior da estufa foram superiores aos medidos externamente. No entanto, para dias com umidade relativa média alta, os valores no interior da estufa foram inferiores. $\mathrm{Ou}$ seja, observou-se menor amplitude na umidade relativa média medida no interior da estufa (Figura 20). Esses valores menores na umidade relativa medida no interior da estufa podem ter ocorrido devido ao manejo empregado, pois as estufas são fechadas lateralmente com tela anti-afídios e possuem cortinas em polietileno móveis, que são fechadas em dias chuvosos, dificultando as trocas com o ambiente externo.

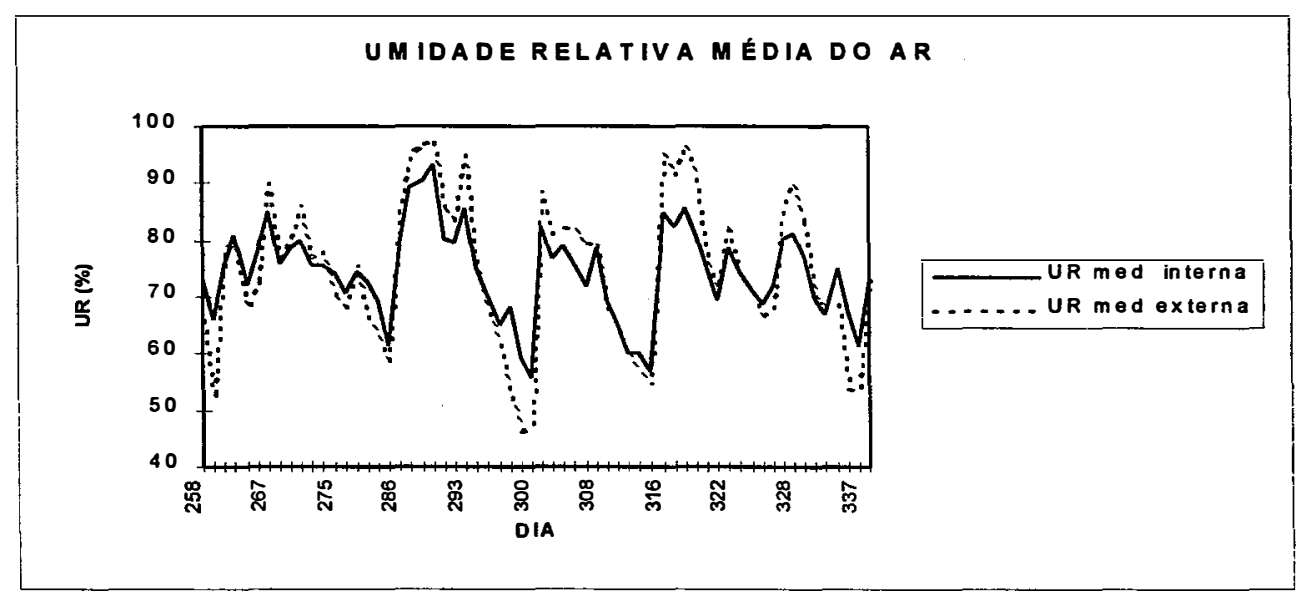

Figura 20 - Dados médios de UR\% no interior e externamente à estufa

Trabalhando-se com dados médios totais, observou-se que os valores de UR do ar no interior da estufa plástica são similares aos observados a céu aberto (Tabela 14 apêndice), sendo que no período de estudos a média interna foi de $74,8 \%$ e a externa foi de $75,6 \%$, ou seja, uma variação inferior a $1 \%$.

Porém, analisando-se a sua evolução ao longo do dia verificaram-se variações maiores no interior da estufa, com valores elevados à noite (próximos de $100 \%$ ) e muito baixos durante o período diurno (próximos de 20\%) (Figura 21). 


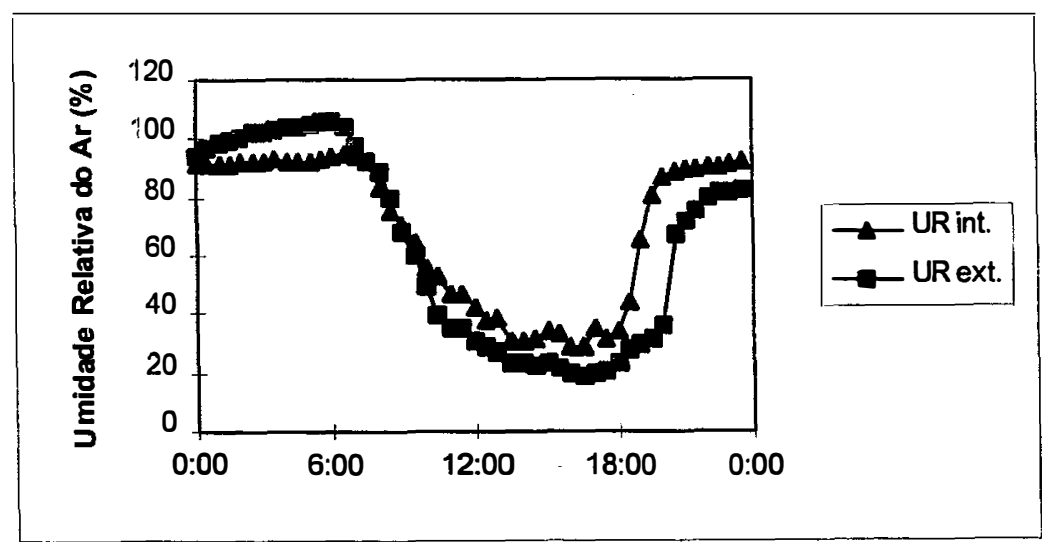

Figura 21 - Comparação UR int. e ext. (dia 11/10/95)

O efeito da estufa sobre a temperatura do ar está relacionado com o balanço de energia sendo, portanto, dependente de fatores como as condições da superficie e ângulo de incidência da radiação solar. Outros fatores também podem afetar a temperatura do ar, como o tipo de solo, as dimensões da estufa e seu volume.

Durante o período de estudos (setembro a início de dezembro), observou-se que a temperatura média no interior da estufa foi sempre mais alta que no exterior, conforme pode ser constatado na Figura 22. Durante todo o período, a temperatura média externa foi de $21,8^{\circ} \mathrm{C}$ enquanto que a temperatura interna teve uma média de $23,7^{\circ} \mathrm{C}$, com variações de $0,02^{\circ} \mathrm{C}$ até $10,02^{\circ} \mathrm{C}$. Com relação à temperatura máxima, a média interna foi de $32,9^{\circ} \mathrm{C}$ e a externa foi de $28,8^{\circ} \mathrm{C}$, com variações de 0,81 a $9,87^{\circ} \mathrm{C}$, chegando a atingir valores de $42^{\circ} \mathrm{C}$ no interior da estufa no dia 02 de dezembro, conforme mostra a Figura 24. A temperatura mínima teve média interna de $17,3^{\circ} \mathrm{C}$ e externa de $16,4^{\circ} \mathrm{C}$, com variações de $-2,0$ até $2,6^{\circ} \mathrm{C}$ (Figura 26). 


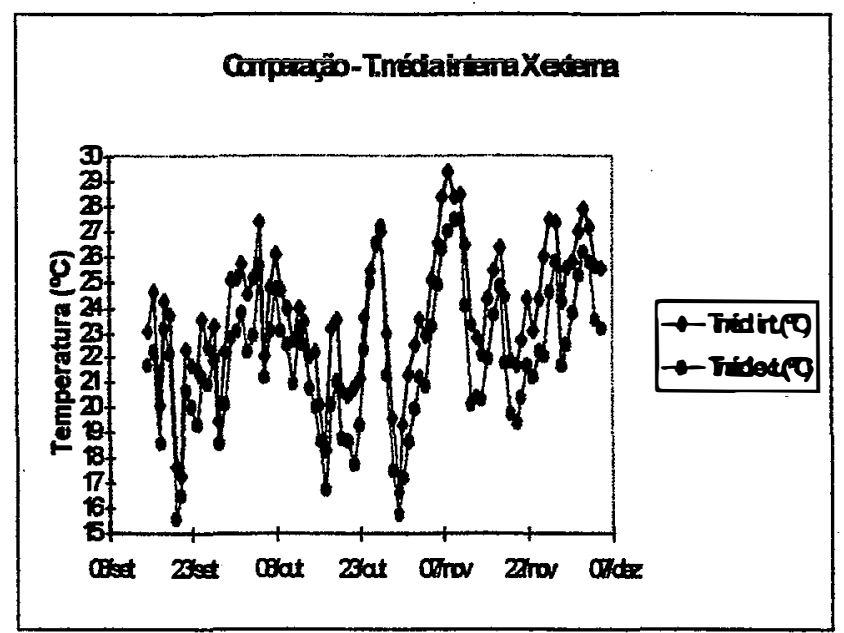

Figura 22 - Temperatura média no interior da estufa

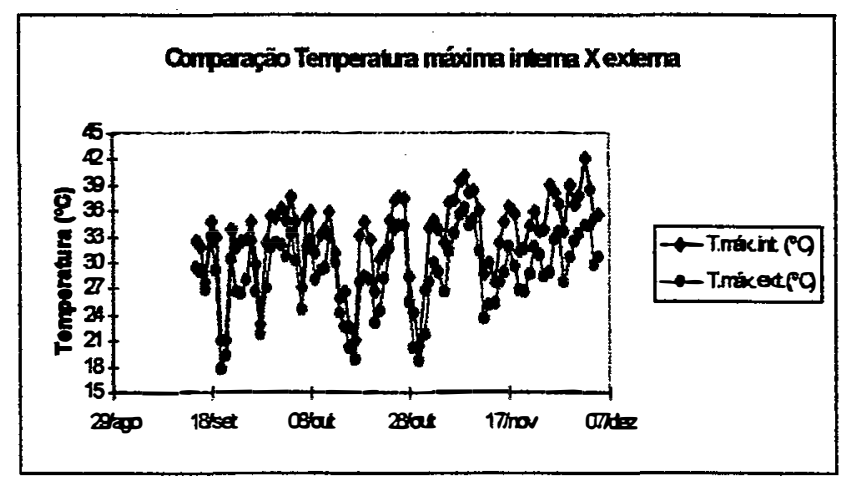

Figura 24 - Temperatura máxima no interior da estufa

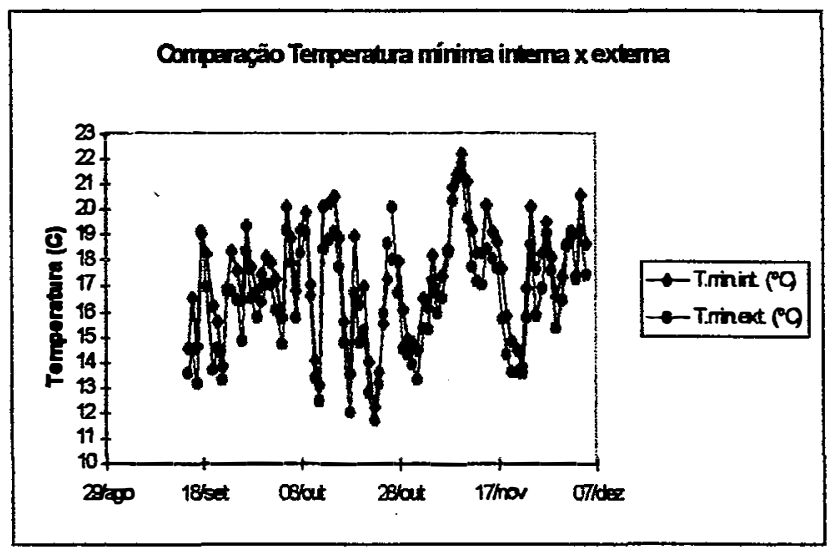

Figura 26 - Temperatura mínima no interior da estufa

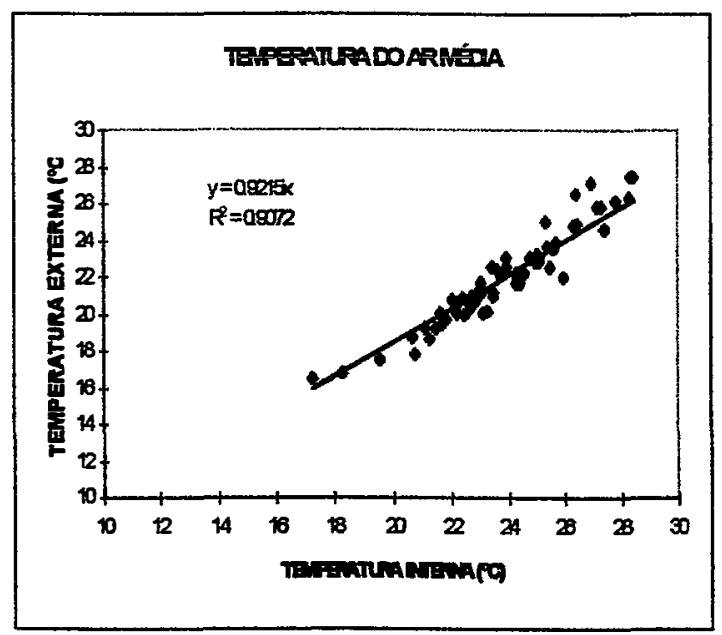

Figura 23 - Regressâo linerar $T$ (média) int.x ext

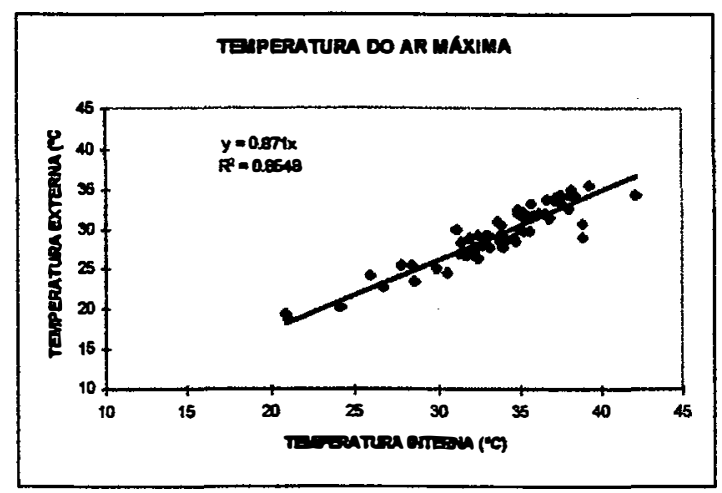

Figura 25 - Regressão linerar T(max) int.x ext

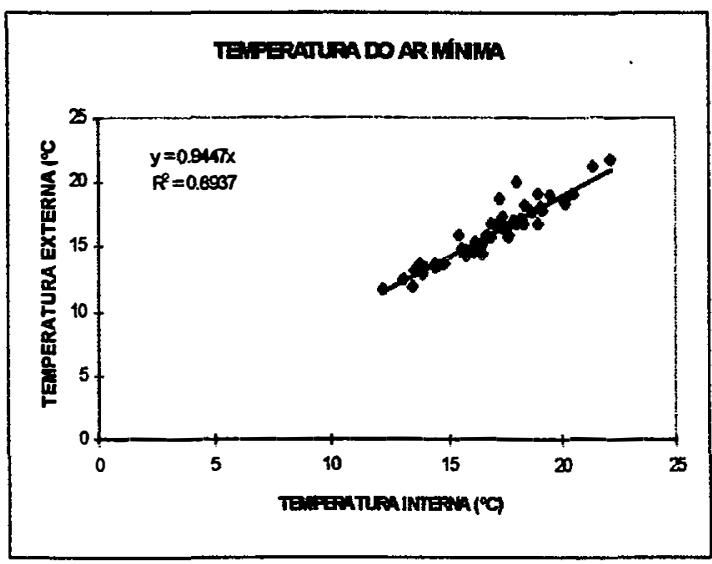

Figura 27 - Regressão linerar T(min) int.x ext 
Os valores de Temperatura média, máxima e mínima do ar foram, em média, $8,5 \%, 14,8 \%$ e $5,9 \%$ maiores no interior da estufa plástica, quando comparados com os valores externos (Figuras 23, 25 e 27)

Conforme análise dos dados médios, pode-se verificar que a temperatura do ar dentro da estufa atingiu valores sempre maiores que os verificados no ambiente externo, condição típica de cultivos em ambientes protegidos.

Durante o dia, devido à radiação líquida positiva, a superfície aquece a parcela de ar próximo a ela, gerando assim um processo convectivo. Dentro da estufa este processo é interrompido pela cobertura plástica, que impede a ascenção do ar quente, o que provoca temperaturas maiores no período diurno. Em algumas situações, a temperatura do ar dentro da estufa atinge valores muito elevados, podendo causar danos às culturas, sendo então necessária a abertura de janelas laterais.

Segundo ROBLEDO (1987), o plástico usado como cobertura das estufas tem alta transparência à radiação de onda longa, não impedindo então a queda acentuada da temperatura do ar. $\mathrm{Na}$ estufa onde foi conduzido o experimento, também verificou-se uma queda de temperatura no período notumo, conforme pode ser visto na Figura 19.

\subsection{Estimativa da evapotranspiração da cultura dentro da estufa}

Durante o período do ensaio foram feitas estimativas de evapotranspiração através dos modelos descritos no ítem 3.7.4, para comparação com as medidas do lisímetro (Evapotranspiração da cultura do crisântemo).

Para isso, foi estimado um coeficiente de cultura $(\mathrm{Kc})$ para o crisântemo, baseado nas medidas do índice de área foliar (IAF), conforme mostra a Figura 28. 


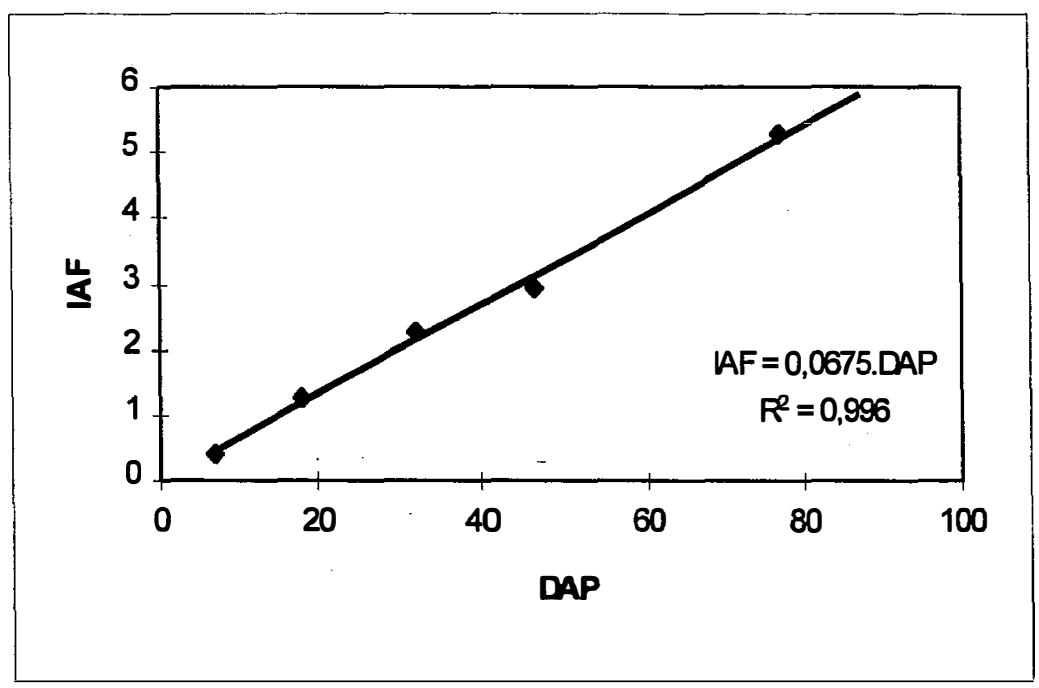

Figura 28 - Determinação do IAF a partir de regressão linear

A partir da equação acima descrita, foram estimados os coeficientes de cultura para os dias de estudo, relacionando os mesmos ao índice de área foliar medido (IAF) e os dias após o plantio (DAP) (Tabela 15 - apêndice)

Utilizando-se os coeficientes de cultura obtidos a partir da relação com o IAF e DAP, a evapotranspiração da cultura foi estimada pelos diferentes métodos descritos, e comparados através de regressões lineares com os dados de evapotranspiração considerados padrões, obtidos através das leituras do lisímetro de pesagem (Figuras 29 e $30)$.

Para a análise dos resultados foram considerados o coeficiente de determinação $\left(r^{2}\right)$ e o índice de ajuste (“index of agreement") $d$.

O coeficiente de determinação mede a dispersão dos dados estimados em relação à reta da equação, enquanto que o índice de ajuste mede a dispersão dos dados em. relação à linha $1: 1$, isto é, mede a exatidão dos valores estimados em relação aos medidos.

O coeficiente de determinação é calculado pela razão entre a soma de quadrados da regressão e a soma de quadrados dos termos observados e representa a variação de $\mathrm{Y}$ (evapotranspiração) que é explicada pela regressão (PEREIRA e ARRUDA, 1987). 
O "índice de concordância" foi proposto e usado por Willmott $\left(1982^{6}, 1981^{7}\right)$ e Willmott e Wicks $(1980)^{8}$, citados por WILLMOTT (1982) de acordo com a eq. (24) abaixo:

$$
d=1-\left[\sum_{i=1}^{n}(P i-O i)^{2} / \sum_{i=1}^{n}\left(\left|P^{\prime} i\right|+\left|O^{\prime} i\right|\right)^{2}\right], 0 \leq d \leq 1
$$

onde $P$ é o valor previsto e $O$ o valor observado, sendo $P^{\prime} i=P i-\bar{O}$ e $O^{\prime} i=O i-\bar{O}$. O índice $d$ tem por objetivo ser uma medida descritiva, e é igualmente uma medida relativa e restrita que pode ser facilmente aplicada para fazer comparações cruzadas entre modelos. Através desse índice, é possível se determinar se o erro ếstemático ou não.

Os valores de coeficiente de determinação $\left(\mathrm{r}^{2}\right)$, os coeficientes de regressão (a) e (b) e o índice de concordância (d), estão dispostos na Tabela 15, para os diferentes métodos de estimativa.

Conforme podemos observar nos valores de dispersão, a diferença entre os dados estimados e observados varia bastante de método para método, com valores de índices de correlação desde $20 \%$ até $77 \%$, e valores de d entre 55 e $90 \%$.

Os métodos de Penman-Monteith, Camargo, Makkink, Linacre e Tanque evaporimétrico, subestimaram a evapotranspiração medida, de 3 até $58 \%$ e os métodos de Penman, Radiação solar, Jensen-Haise, Hargreaves-Samani e Penman-simplificado superestimaram a ET medida, desde 18 até $50 \%$.

Essas variações podem ser explicadas pelas diferenças entre os métodos de estimativa, conforme visto no índice 3.7.4, seja no tipo de dados utilizados, seja nas

\footnotetext{
${ }^{6}$ Willmott, C. J. On the climatic optimization of the tilt and azimuth of flat-plate solar collectors. Solar Energy, n.28, p.205-216, 1982.

${ }^{7}$ Willmott, C. J. On the validation of models. Phys. Geogr., n.2, p.184-194, 1981.

${ }^{8}$ Willmott, C. J.; Wicks, D. E. An empirical method for the spatial interpolation of monthly precipitation within California. Phys. Geogr., n.1, p.59-73, 1980.
} 
diferentes condições climáticas de origem dos mesmos, que podem acarretar em diferenças significativas nas estimativas.

Tabela 16 - Comparações dos dados estimados X dados observados

\begin{tabular}{|c|c|c|c|c|}
\hline \multirow[t]{2}{*}{ Métodos } & \multicolumn{2}{|c|}{ Coeficientes de regressão } & \multirow[t]{2}{*}{$r^{2}$} & \multirow[t]{2}{*}{ d } \\
\hline & a & b & & \\
\hline Penman-Monteith & $-0,1645$ & 0,5883 & 0,6865 & 0,7485 \\
\hline Camargo & 0,4624 & 0,8014 & 0,5929 & 0,8722 \\
\hline Penman & $-0,4300$ & 1,1989 & 0,7312 & 0,7662 \\
\hline Makkink & $-0,5318$ & 0,7642 & 0,7550 & 0,8948 \\
\hline Radiação Solar & $-0,9346$ & 1,2684 & 0,7577 & 0,8995 \\
\hline Jensen-Haise & $-0,9400$ & 1,2642 & 0,7689 & 0,8848 \\
\hline Linacre & 0,3104 & 0,9739 & 0,6593 & 0,5561 \\
\hline Hargreaves-Samani & 0,2610 & 1,5066 & 0,6563 & 0,8947 \\
\hline Penman-simplificado & $-0,7418$ & 1,3651 & 0,6924 & 0,8518 \\
\hline Tanque evaporim. & 0,0128 & 0,4224 & 0,4168 & 0,6466 \\
\hline
\end{tabular}

No método de Makkink, por exemplo, são utilizados na equação geral dois coeficientes, que foram determinados através de experimentos realizados em Wageningen, Holanda, com condições climáticas diferentes das que caracterizam a região do presente trabalho. Nesta equação, os coeficientes utilizados foram $a=-0,12 \mathrm{e}$ $b=0,61$, conforme a equação descrita no ítem 3.7.4 deste trabalho.

Utilizando-se os valores medidos com o lisímetro (evapotranspiração observada), fez-se uma regressão linear para estimar os novos coeficientes da equação de Makkink para a região de Arthur Nogueira-SP, dentro da estufa de cobertura plástica. Os coeficientes para a referida região, segundo a regressão mostrada na Figura 31 foram: $a=0,5335$ e $b=0,5934$. 

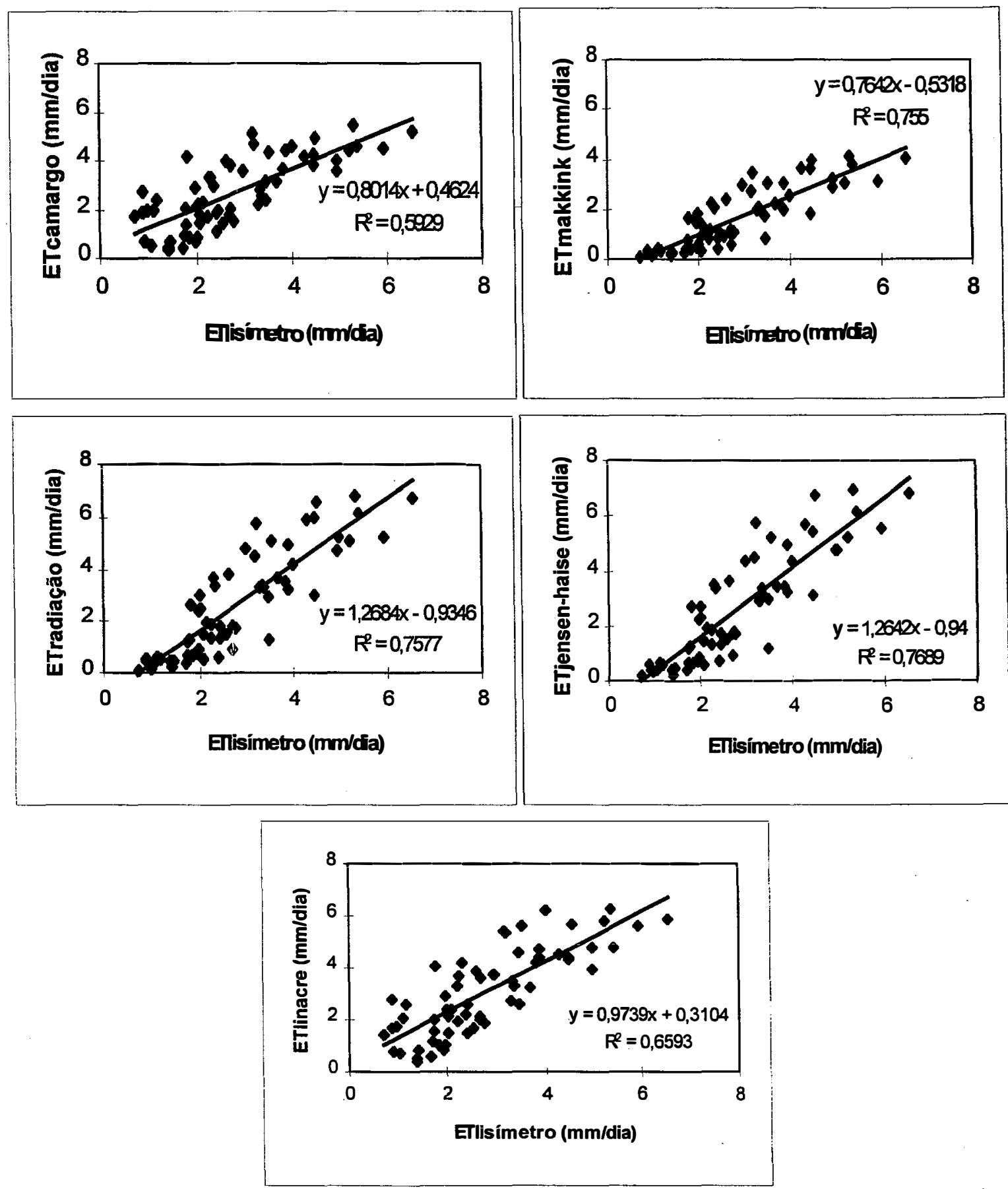

Figura 29 - Comparações dos diferentes métodos de estimativa com o lisímetro (regressão linear) 

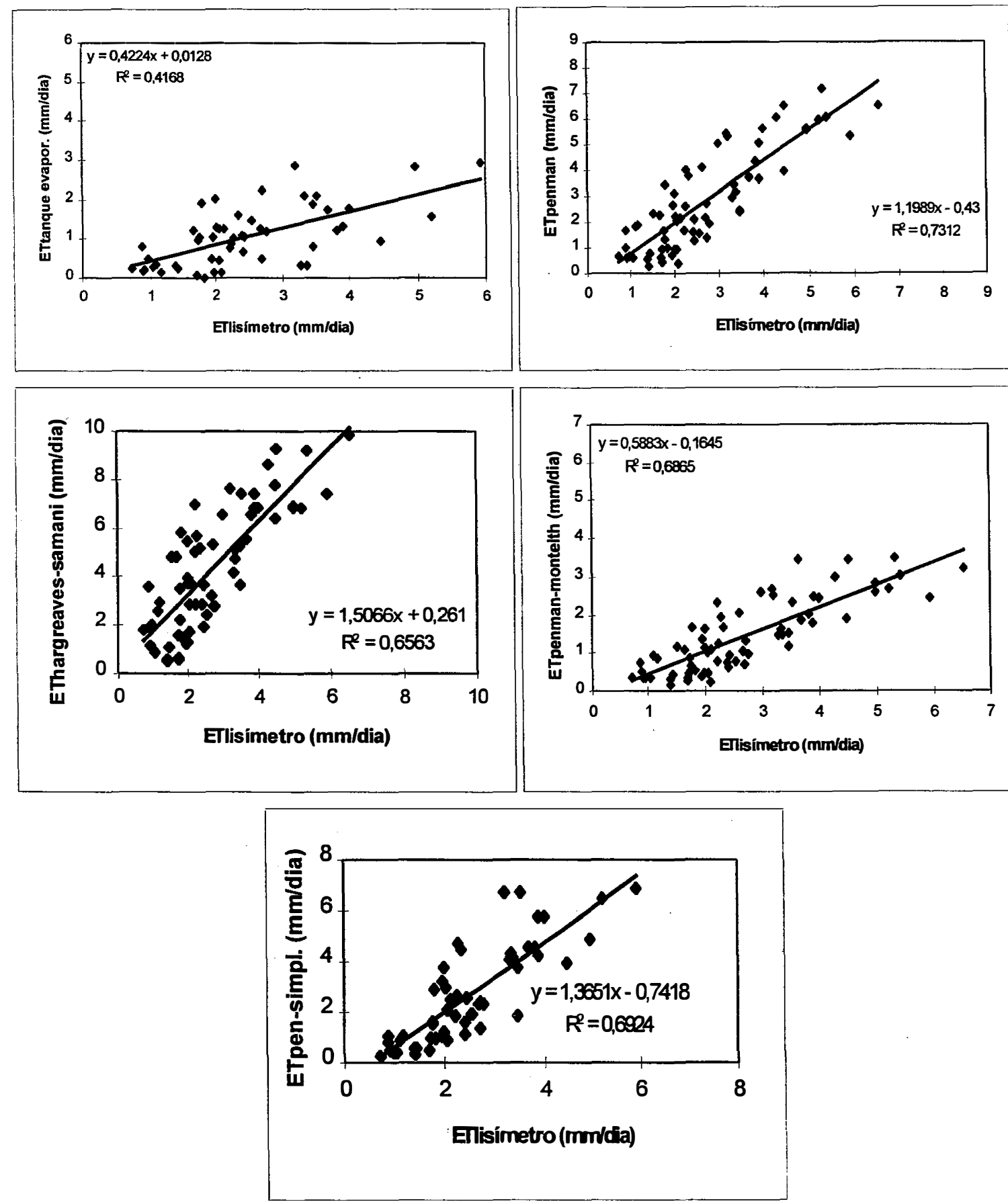

Figura 30 - Continuação das comparações dos diferentes métodos de estimativa com 0 lisímetro 
Utilizando-se a equação de Makkink com estes coeficientes para a região de Arthur Nogueira, em cultivo protegido em estufa, a estimativa da evapotranspiração poderá ser feita de maneira mais precisa.

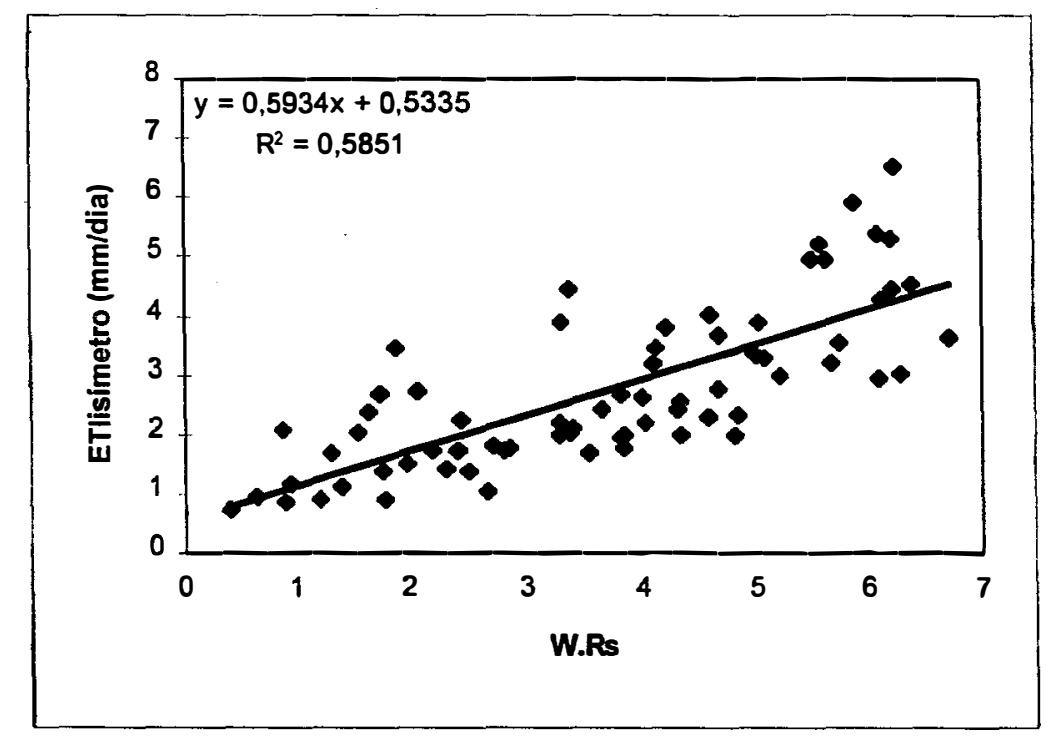

Figura 31 - Determinação dos coeficientes a e b de Makkink

Mesmo com a utilização dos coeficientes obtidos em condições adversas às do trabalho, o método de Makkink se comportou de maneira satisfatória para estimar a evapotranspiração da cultura, quando comparado com as medidas do lisímetro, sendo obtidos valores de $75,50 \%$ e $76,62 \%$ para $\mathrm{r}^{2}$ e $\mathrm{d}$, respectivamente. Basicamente, este método utiliza dados de radiação solar e temperatura, elementos bem definidos dentro da estufa.

Com relação ao método da radiação solar, que na verdade é uma adaptação do modelo de Makkink feita por Doorenbos \& Pruitt (1975), também houve boa correlação entre os valores estimados e medidos, com $\mathrm{r}^{2}=75,77 \%$ e $\mathrm{d}=\mathbf{8 9 , 4 8 \%}$. A maior diferença entre os dois métodos está na substituição dos coeficientes empíricos a e b por um parâmetro $\mathrm{c}$, função da umidade relativa do ar e da velocidade do vento. A não utilização destes coeficientes melhorou a estimativa da evapotranspiração, sendo este método (Radiação solar) considerado o de segundo melhor ajuste entre aqueles estudados. 
O método de Jensen-Haise, que também utiliza dados de temperatura média do ar e radiação solar não necessita de área tampão homogênea, ilimitada e bem suprida de água, conforme requer a definição de evapotranspiração potencial. Apesar deste método ser preferível para estimativas para períodos entre 5 e 10 dias, a estimativa diária foi a que melhor se comportou na comparação com os dados considerados padrões, resultando em valores de $\mathrm{r}^{2}=76,89 \%$ e $d=89,95 \%$.

O modelo de Camargo, que é uma simplicação da equação de Thornthwaite, estima a ETp a partir de dados de temperatura média do período, corrigidos por um fator F e radiação solar extraterrestre. Os dados de radiação são obtidos em tabelas, e, apesar da sua facilidade de cálculo, apresentou valores um pouco menores de $\mathrm{r}^{2}(59,29 \%)$ e d (87,22\%), quando comparados com os métodos que utilizam medidas da radiação solar, como Jensen-Haise, Makkink e Radiação solar.

O método de Linacre foi desenvolvido para estimar a evapotranspiração mensal média de uma vegetação bem suprida de umidade. Quando utilizado para estimar a evapotranspiração diária, como é o caso do presente trabalho, os valores de correlação e ajuste foram de $65,93 \%$ e $88,48 \%$ para $r^{2}$ e d, um pouco abaixo daqueles encontrados nos métodos que utilizam dados de temperatura média e radiação solar. Os coeficientes utilizados na equação de Linacre foram obtidos a partir de 222 conjuntos de dados da África e da América do Sul, sendo que Pereira (1994) afirma que esta equação deve ser usada com reserva para as condições brasileiras, devido à falta de informação referente à transformação destes coeficientes.

Hargreaves \& Samani utilizam dados de radiação extraterrestre e temperatura (média, máxima e mínima) para estimar a evapotranspiração, cuja equação foi obtida a partir de dados do lisímetro de Davis, California, em gramado. No presente trabalho, como eram disponíveis dados de radiação solar global, estes foram preferidos para a estimativa da evapotranspiração, evitando assim uma estimativa a partir de dados tabelados de radiação extraterrestre. Mesmo com o uso destes dados, as estimativas resultaram em valores baixos de $\mathrm{r}^{2}$ e d, respectivamente $65,63 \%$ e 55,61\%. A obtenção 
de tais índices ocorreu provavelmente devido à alteração das condições específicas de El Salvador, local de gênese do método.

Com relação ao tanque evaporimétrico, é conveniente ressaltar algumas pequenas mudanças estruturais do modelo utilizado em relação ao Tanque Classe A considerado padrão. $\mathrm{O}$ tanque padrão é construído com chapa de ferro galvanizado, com $121 \mathrm{~cm}$ de diâmetro e $25,5 \mathrm{~cm}$ de profundidade, pintado interna e externamente com tinta aluminizada. O tanque utilizado no experimento foi construído com medidas menores que as consideradas padrões, por ser mais viável para a sua utilização em estufas. As medidas do tanque eram $50 \mathrm{~cm}$ de diâmetro e $25 \mathrm{~cm}$ de profundidade. Essa alteração de medida de diâmetro aliada à utilização de Kp não desenvolvido para cultivo específico em estufas foram os fatores que provavelmente causaram a obtenção de baixos valores de $\mathrm{r}^{2}(41,68 \%)$ e d $(74,85 \%)$. Através da Figura 32, é possível visualizar as diferenças entre os valores de ET medida e ET estimada pelo método do tanque.

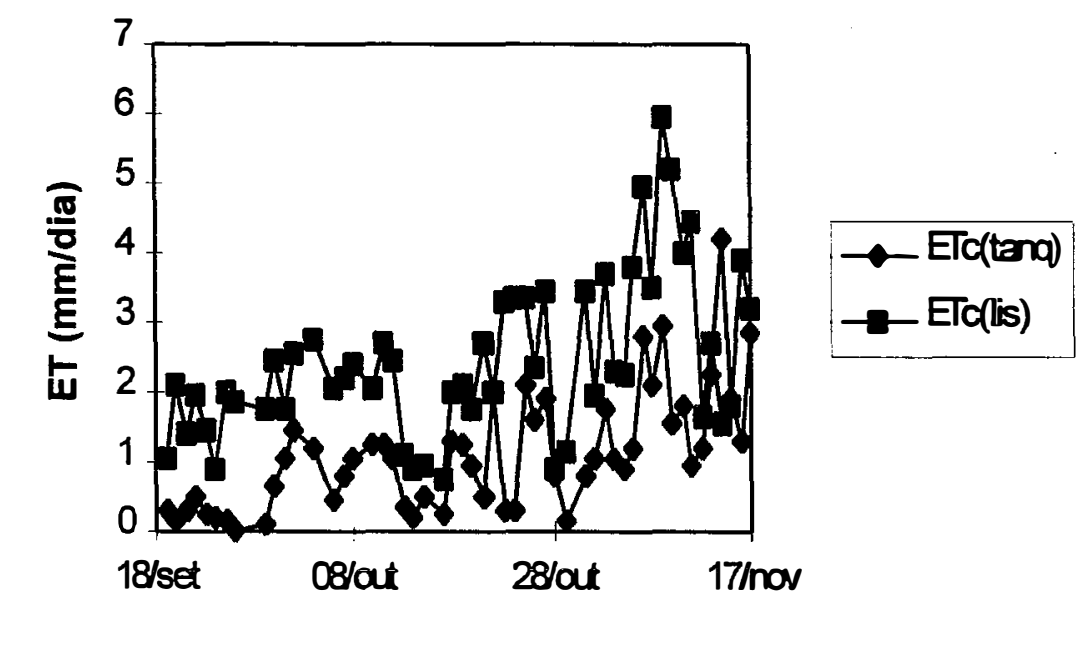

Figura 32 - Comparação ETlisímetro X ETtanque evaporimétrico

O método de Penman, apesar de utilizar grande número de dados para a estimativa da evapotranspiração potencial, apresentou valores de $r^{2}(73,12 \%)$ e d $(89,47 \%)$ abaixo de alguns modelos bem mais simples, como Makkink, Jensen-Haise e 
Radiação Solar. O mesmo ocorre com o modelo de Penman-Monteith, com índices ainda mais baixos de $r^{2}(68,65 \%)$ e d (64,66\%). Esses menores valores de correlação foram decorrentes provavelmente das estimativas de resistência do dossel $\left(r_{c}\right)$ e resistência aerodinâmica $\left(\mathrm{r}_{\mathrm{a}}\right)$, devido à inexistência de aparelhos específicos de medida. Já a variação da equação de Penman que utiliza valores da evaporação de Piche resultou em valores de $\mathrm{r}^{2}=69,24 \%$ e $\mathrm{d}=85,18 \%$, valores também inferiores aos encontrados em alguns métodos mais simples de estimativa.

Diantes destes valores obtidos de $\mathrm{r}^{2}$ e d, é possível se concluir que para as condições do trabalho se apresenta mais viável a utilização de modelos mais simples de estimativa da evapotranspiração, não só pela sua maior facilidade de cálculo, mas também pelos melhores resultados obtidos quando comparados aos métodos mais complexos.

Mesmo com os métodos onde a correlação entre os valores observados e estimados foram maiores, não se obtiveram altos $\mathrm{r}^{2}$ (todos abaixo de $80 \%$ ). Esse fato pode ser explicado pelo período utilizado para se fazer as comparações, 4 meses, com dados diários de evapotranspiração, onde a dispersão dos dados pode ser considerada maior que em comparações feitas em períodos mais longos (estimativas mensais, por exemplo).

\subsection{Comparação da Evapotranspiração interna e externa}

Com os sensores instalados externamente à estufa, estimou-se a evapotranspiração potencial no ambiente, sendo esta comparada com a evapotranspiração potencial interna.

Na Figura 33, encontram-se os valores de ETp para o método de Camargo. Conforme podemos observar, os valores de evapotranspiração interna são sempre maiores que os externos. Isso pode ser explicado pela equação de Camargo, que utiliza 
dados de temperatura média para o cálculo da ETp, sempre maiores no interior de uma estufa com cobertura plástica.

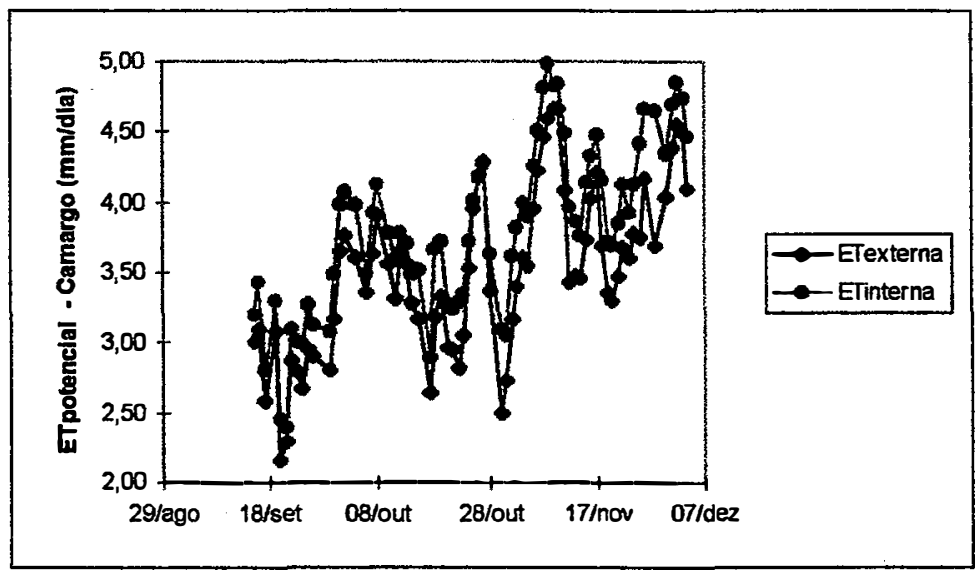

Figura 33 - Comparação ET interna e externa (Camargo)

Quando se comparou os valores estimados através do método de Penman, observou-se uma alternância entre os valores de ET interna e externa, com a predominância de maiores valores de evapotranspiração interna ( de 5 a 35\% maiores), conforme a Figura 34.

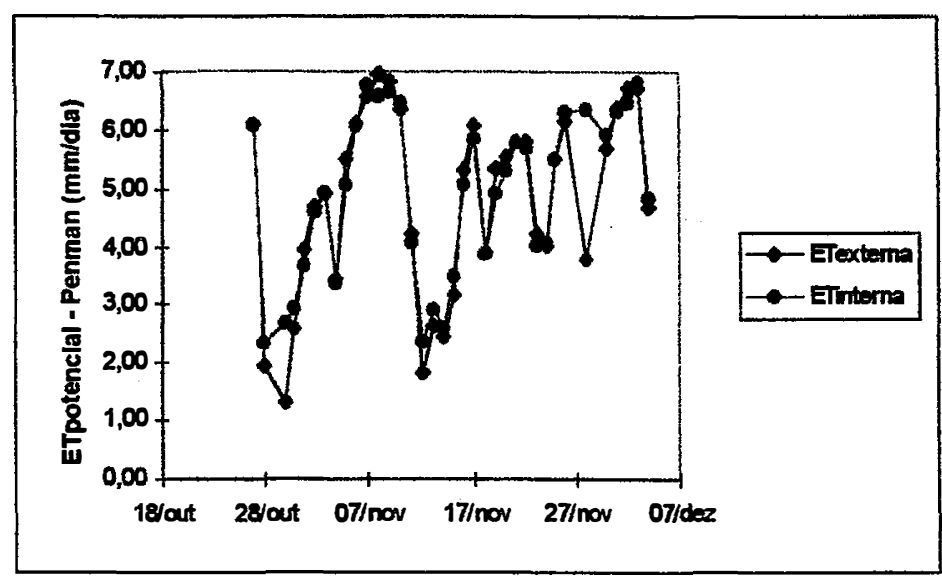

Figura 34 - Comparação ET interna e externa (Penman) 


\subsection{Comparação do manejo da irrigação através do lisímetro e manejo tradicional do produtor}

Antes da utilização das informações do lisímetro para se promover o controle da irrigação da cultura em estufa, utilizou-se o mesmo para avaliar o manejo adotado pela empresa. Durante um tempo prédeterminado, foram feitas leituras de lâmina de água aplicada pelos sistemas de irrigação da estufa, sendo que o turno de rega e o tempo de irrigação eram definidos pelos técnicos responsáveis da empresa. A Figura 35 mostra os valores obtidos, ficando bastante clara a falta de critérios para definição do turno de rega e quantidade de águạ a ser aplicada para a cultura.

A partir de novembro de 1995, foi possível a alteração do manejo da irrigação, sendo então definido a partir dos dados do lisímetro instalado num dos canteiros experimentais. Definiu-se um nível de armazenamento mínimo de água no solo, a partir do qual era feita uma irrigação para repor exatamente a evapotranspiração verificada no período.

Dessa forma, o turno de rega aumentou, bem como a lâmina aplicada em cada irrigação.(Figura 36). 

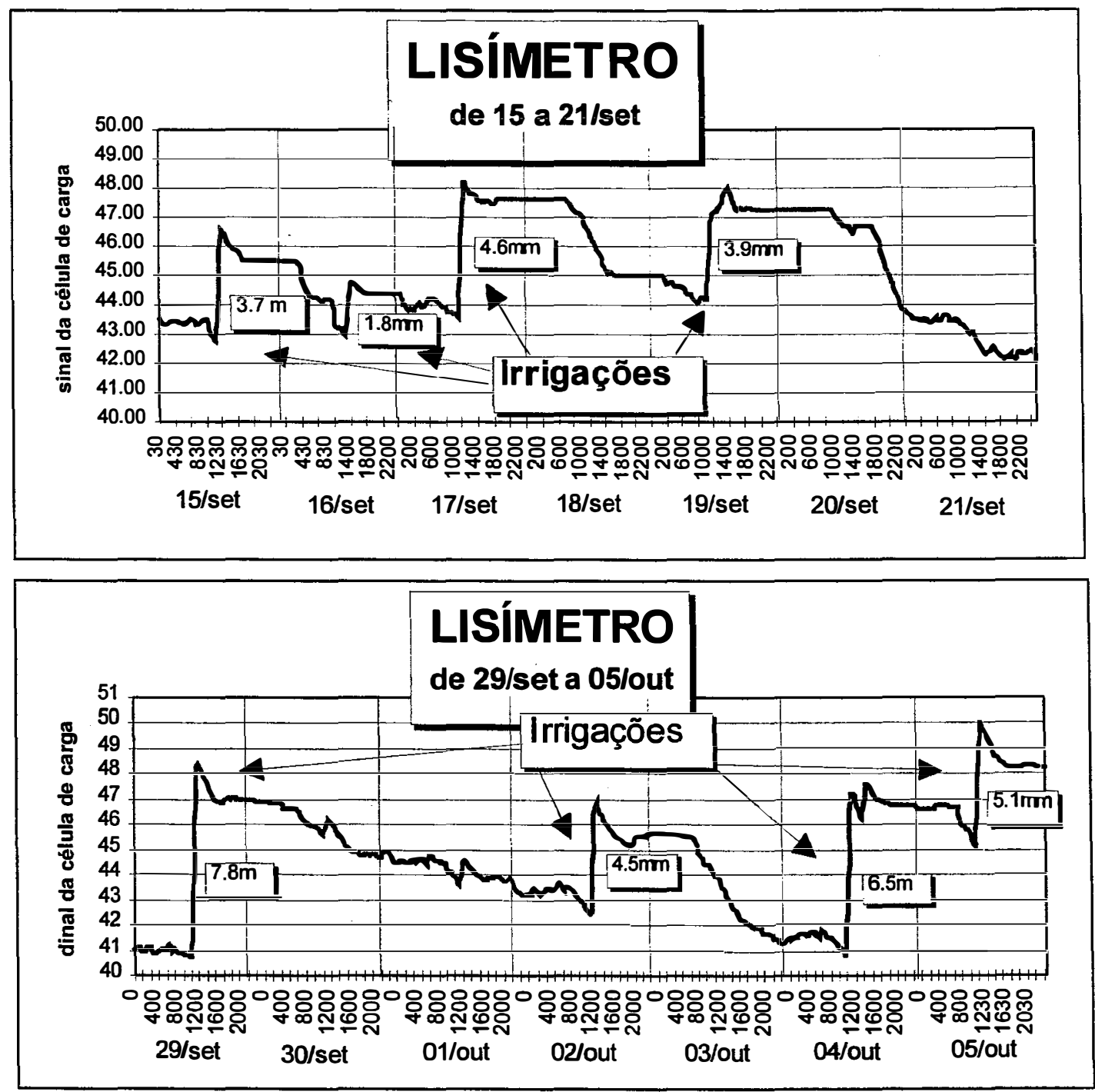

Figura 35 - Resumos semanais das irrigações e evapotranspirações medidos através do lisímetro com o manejo da irigação a critério da empresa. 

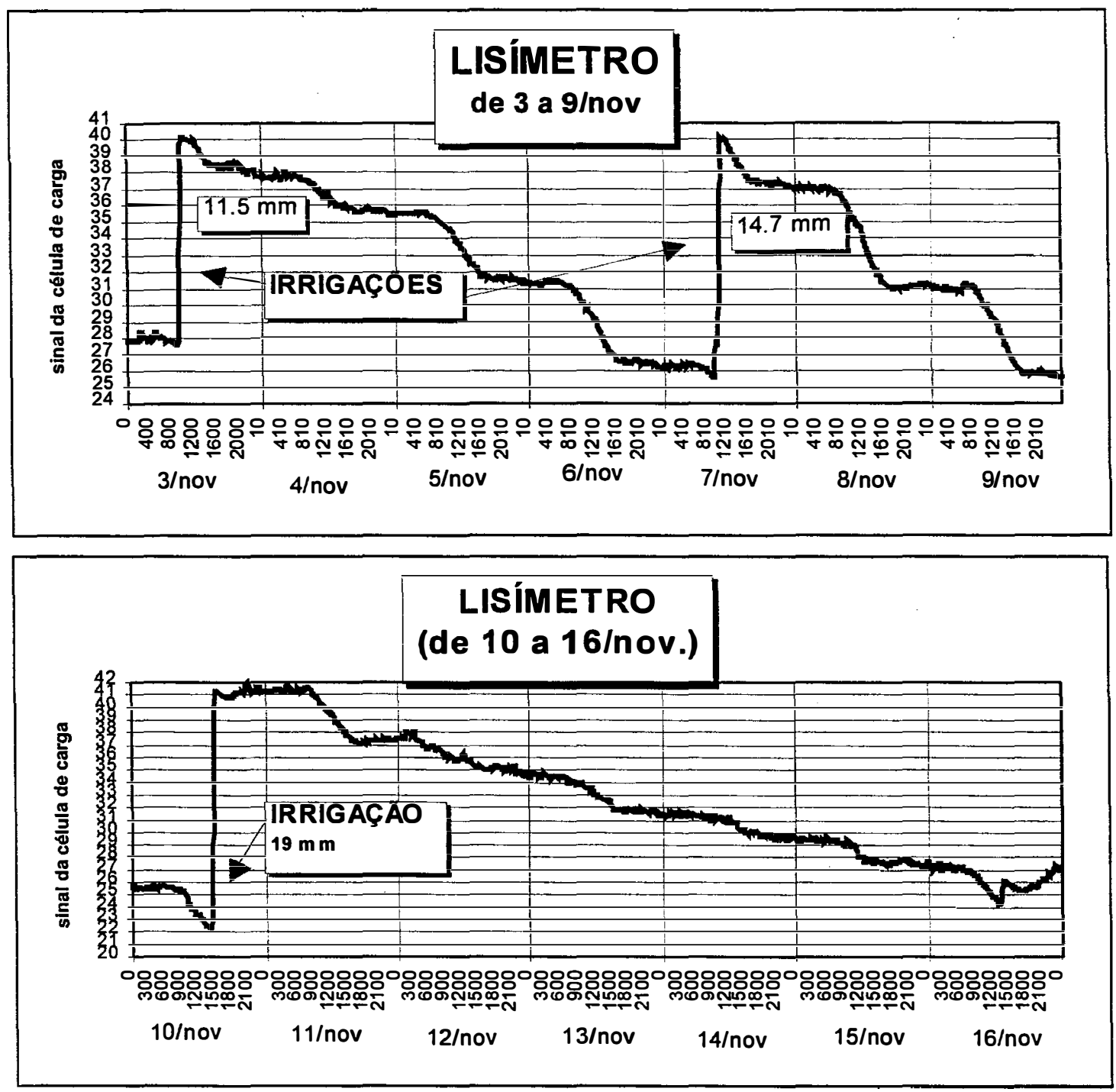

Figura 36 - Resumos semanais das irrigações e da evapotranspiração nas semanas onde foi feito o manejo através dos dados do lisímetro de célula de carga.

Nesses gráficos pode-se notar que na semana de 3 a 9 de novembro houve apenas 2 irrigações, sendo que na irrigação do dia 7 de novembro, aplicou-se a mesma quantidade de água que evapotranspirou desde a última irrigação (14,7 mm em rês dias). Já na semana de 10 a 16 de novembro, houve apenas uma irrigação no início da semana, uma vez que as taxas de evapotranspiração não foram acentuadas $(17,5 \mathrm{~mm}$ um período de 6 dias). 
Ainda analisando as figuras 36 e 37, é possível perceber que durante o novo manejo, o solo foi mantido com níveis inferiores de umidade, o que implica em uma redução na possibilidade de danos à cultura por excesso de água no solo.

$\mathrm{O}$ fato de manter o solo em níveis inferiores de umidade não prejudicou a produção da cultura com relação à quantidade e qualidade de estacas colhidas por área. Em ambos os tratamentos (manejo tradicional $\mathrm{x}$ manejo através do lisímetro) foram colhidas estacas por um funcionário especializado, e não se verificaram diferenças significativas com relação à qualidade e número de estacas obtidas. 


\section{CONCLUSÕES}

A partir das informações coletadas, processadas e interpretadas nesta pesquisa, foram obtidas as seguintes conclusões:

a) Verificou-se uma redução de cerca de $30 \%$ dos valores de radiação solar, devido à perda de transmissividade decorrente do plástico, um PE de baixa densidade de $150 \mu \mathrm{m}$.

b) Os valores de temperatura média, máxima e mínima foram sempre mais elevados no interior da estufa, condição típica dos cultivos em ambientes protegidos.

c) O lisímetro de pesagem com célula de carga mostrou-se bastante simples e eficiente para a determinação da necessidade de água da cultura, sendo também utilizado como método padrão para comparação dos diferentes métodos de estimativa da evapotranspiração.

d) As melhores correlações e concordâncias entre os valores estimados e medidos da evapotranspiração da cultura foram obtidas quando se utilizaram métodos que tinham como entrada valores de radiação solar e temperatura. Esses método foram: Jensen \& 
Haise ( $\mathrm{r}^{2}=76,89 \%$ e d $\left.=89,95 \%\right)$, Radiação Solar $\left(\mathrm{r}^{2}=75,77 \%\right.$ e $\left.d=89,48 \%\right)$ e Makkink $\left(r^{2}=75,50 \%\right.$ e d $\left.=76,62 \%\right)$.

e) Apesar de se tratar de um método bastante utilizado e recomendado pela FAO, o método do tanque evaporimétrico não se ajustou satisfatoriamente com os dados medidos. As principais causas eventuais para tal comportamento são: utilização de coeficiente de tanque $(\mathrm{Kp})$ não específico para estufa ,alteração do diâmetro padrão do tanque utilizado no experimento e não calibração deste tanque com um Tanque Classe $\mathrm{A}$ padrão.

f) Os modelos de Penman, Penman-Monteith e Penman-piche apresentaram valores de coeficiente de determinação e índice de concordância inferiores a alguns método bem mais simples, como os métodos de Jensen-Haise, Makkink e Radiação Solar. Tendo em vista esses resultados, conclui-se que é mais viável, nas condições do presente estudo, utilizar modelos mais simples, pela facilidade de cálculo e melhor estimativa da evapotranspiração.

g) Através das leituras do lisímetro de pesagem, foi possível avaliar o controle da irrigação adotado convencionalmente pela empresa, e concluir que não há nenhum critério para tal procedimento no que diz respeito à quantidade de água a ser aplicada e quando a mesma deve ser aplicada.

h) Com o manejo realizado a partir das leituras do lisímetro, observou-se que o solo foi mantido em níveis mais baixos de umidade, com relação ao manejo tradicional, além do intervalo entre irrigações ter sido maior. Apesar do fato do solo ter sido mantido a níveis mais baixos de umidade, não foi verificada diferença significativa de produção de estacas de crisântemo, nem na quantidade de estacas produzidas por planta nem na qualidade das mesmas. 


\section{REFERÊNCIAS BIBLIOGRÁFICAS}

ABOUKHALED, A.; ALFARO, A. ; SMITH, M. Lysimeters ., Rome: FAO, 1982, 68p. ( Irrigation and Drainage Paper, 39)

ALFONSI, R.R.; PEDRO JR., M.J.; ARRUDA, F.B.; ORTOLANI, A.A. ; CAMARGO, M.B.P. ; BRUNINI, O. Métodos agroclimatológicos para controle da irrigação. Instituto Agronômico de Campinas, Campinas: 1990, 62p (Boletim Técnico, 133)

ALLEN, R.G. A Penman for all seasons. Journal of Irrigation and Drainage Engineering, v.112, n.4, p.348-68, 1996.

ALLEN, R.G. ; FISHER, K. Direct load cell-based weighing lysimeter system. Lysimeters for Evapotranspiration. p.114-24, 1992.

BAILlE, A. Water status monitoring in greenhouse crops. Acta Horticulturae, v.304, p.15-27, 1992.

BAILLE, M. ; BAILLE, A. Some comparative results on evapotranspiration of greenhouse ornamental cropos, using lysimeter, greenhouse $\mathrm{H}_{2} \mathrm{O}$ balance and LVDT sensors. Acta Horticulturae, v.304, p.199-208, 1992. 
BARBOSA, J.G. ; MARTINEZ, H.F.P. O cultivo hidropônico do crisântemo. Viçosa: Universidade Federal de Viçosa, Conselho Técnico de Extensão, 1995, 8p.

BAUSCH, W. C. Sensor height effects on calculated reference evapotranspiration. Transactions of the ASAE, v.33, n.3. p.791-9, 1990.

BERLATO, M.A. ; MOLION, L.C.B. Evaporação e evapotranspiração. Porto Alegre: IPAGRO, 95p., 1981. (IPAGRO, Boletim Técnico, 7)

BERNARDO, S. Manual de Irrigação. Viçosa; , UFV, Imprensa Universitária , $1989,463 p$.

BLACK, T. A.; THURTTELL, G.W. ; TANNER, C. B. Hydraulic load-cell lysimeter, construction, calibration and tests. Soil Science Society of American Proceedings v.32., p.623-9, 1968.

BURIOL, G.A.; SCHNEIDER, F.M. ; ESTEFANEL, V.; ANDRIOLO, J.L. ; MEDEIROS, S.L.P. Modificação na temperatura mínima do ar causada por estufas de polietileno ransparente de baixa densidade. Revista Brasileira de Agrometeorologia, v.1, p. 43-9, 1993.

BURMAN, R.F. Water requirements. In: Jensen, M.E. Design and operation of farm irrigation systems. St. Joseph: The American Society of Agricultura Engineers, 1983, p. 189-231.

CAMARGO, A.P. Contribuição para a determinação da evpotranspiração potencial do estado de São Paulo. Campinas: IAC, 1996, 56p. 
CAMARGO, A.P. \& CAMARGO, M.B.P.de Estimativa da Evapotranspiração potencial utilizando-se dados de temperatura do ar. In: III Congresso Brasileiro de Agrometeorologia, p.229-244, 1983.

CAMPBELL, E. C. ; TANNER, B. D. Structered design in automated weather stations. In: Weiss. A. Computer Techniques and Meteorological Data Applied to Problems of Agriculture and Forestry: a workshop. Anaheim: California. p.518,1981 .

DOORENBOS. J. ; PRUIT, J. O. Guidelines for predicting crop water requirements. Rome: FAO. 1977, 144p. (FAO Irrigation and Drainage Paper, 24).

DOOREMBOS, J. ; KASSAN, A.H. Yield response to water. Rome: FAO, 1979, 193p. (FAO Irrigation and Drainage Paper, 33).

DOURADO NETO, D. ; SAAD, A.M. ; VAN LIER, Q. J. Métodos de controle da Irrigação. In: Dourado Neto et al. Curso de Agricultura Irrigada, Piracicaba: ESALQ, Depto. de Agricultura, p.85-98, 1991.

FARIAS, J.R.B.; BERGAMASCHI, H. ; MARTINS, S.R. Evapotranspiração no interior de estufas plásticas. Revista Brasileira de Agrometeorologia, v.2, p.17-22, 1994.

FARIAS, J.R.B.; BERGAMASCHI, H. ; MARTINS, S.R ; BERLATO, M. A. Efeito da acobertura plástica de estufa sobre a radiação solar Revista Brasileira de Agrometeorologia, v.1, p.31-6, 1993a 
FARIAS. J.R.B.; BERGAMASCHI, H. ; MARTINS, S.R.; BERLATO, M. A. ; OLIVEIRA, A.C.B. Evapotranspiração no interior de estufas plásticas. Revista Brasileira de Agrometeorologia, v.1, p.51-62, 1993b

FUJIOKA, F. M ; FORBERG, M. A. Design of a weather statio network for natural resource management. In: Weiss. A. Computer Techniques and Meteorological Data Applied to Problems of Agriculture and Forestry: a workshop. Anaheim, California. p.28- 35, 1981 .

FYNN. R.P.; AL-SHOOSHAN, A.; SHORT,T.H. ; McMAHON, R.W. Evapotranspiration Measurement and Modeling for a Potted Chrysanthemuym crop. Transactions of the ASAE, v.36, n.6, p.1907-13, 1993.

GANGOPADHYAYA, M. et all. Measurements and estimation of evaporation and evapotranspiration. Geneva: WMO, 1966, 121p. (WMO Technical Note , 83).

HARGREAVES, H. ; SAMANI, A. Reference crop evapotranspiration from ambiente air temperature. St.Joseph: American Society of Agricultura Engineers, 1985 (ASAE Paper 85-2517).

HARROLD, L. L. Measuring evapotranspiration by lisimetry. In: Evapotranspiration and its role in water resources management. Proc. ASAE, ISt. Joseph, MI, p. 28-33. 1966.

HILL, R. W. Irrigation scheduling. In: Modeling Plant and Soil Systems. p.491-509, 1991. 
HOWELL, T. A.; MEEK, D. W.; PHENE, C. J.; DAVIS, K. R. ; McCORMICK. Automated weather data collection for research on irrigation scheduling. Transactions of the ASAE, v.27, n.2, 1984.

HUBBARD, K. G.; ROSENBERB N. J. ; NIELSEN, D. C. Automated weather data network for Agriculture.. Journal of Water Resource and Planning Management. v.109, n.3, 1983.

JENSEN, M.E. ; HAISE, H.R. Estimating evapotranspiration from solar radiation. Journal of the Irrigation and Drainage Division, v. 89, p.15-41, 1963.

JONES, H. G. Plants and microclimate. $2^{\circ}$ Ed., Cambridge University Press2a. ed., 1992, 428p.,

LIMA, S.F.F. Comparação de métodos de estimativa de evapotranspiração potencial para o Município de Ribeirão Preto - SP. Piracicaba, 1991, Dissertação de Mestrado Escola Superior de Agricultura “Luiz de Queiroz"/Universidade de São Paulo.

LINACRE, E.T. A simple formula for estimationg evaporation rates in various climates, using temperatura data alone. Agricultural Meteorology, v.18, p.409-24, 1977.

LUCHIARI J.A. ; RIHA, S.J. Bulk surface resistance and its effect on evapotranspiration rates in irrigated wheat. Agronomy Journal, v.83, p.888-95, 1991.

MARTIN, D. L. ; STEGMAN, E. C. ; FERERES, E. Irrigation scheduling principles In: HOFFMAN et al. Management of Farm Irrigation systems. St. Joseph, ASAE, 1990, p. 155-99. 
MARTIN, E.C.; NOVOA, A.C. ; GOMES, S.J. Estudio compartivo de las propriedades de diversos materiales utilizados como cobertura en cultivos protegidos. Revista de Plásticos Modernos, v. 308, p.185-9, 1982.

MARTIN, E.C. ; ROBLEDO, L.V. Aplication de los plasticos en la agricultura. Madrid: Mun-Pressa, 1981, 55p.

MARQUES, V. S. Sobre as limitações dos evapotranspirômetros. São Carlos: 1972. 56p., Dissertação de Mestrado - Escola de Engenharia de São Carlos/ Universidade de São Paulo.

MEDINA, A. P. Classificação granulométrica do solo - classes e subclasses texturais. In: CONGRESSO DE CIÊNCIA DO SOLO, 11, Brasília, 1967.

MILLS, P.J.W.; SMITH, I.E.; MORAIS, G. A greenhouse design for a cool subtropical climate with winters based on microclimatic measurements of protected environments. Acta Horticulturae, v. 281p. 83-93, 1990.

MONTEITH. J.L. Evaporation and environment. Symp. Soc. Exp. Biology. London, 19:205-234, 1965.

MONTERO. J.I.; CASTILLA, N.; GUTIERREZ DE RAVÉ, E.; ; BRETONES, F. Climate under plastic in the Almeria. Acta Horticulturae, v. 170, p. 227-234, 1985.

PENMAN, H.L. Natural evaporation from open water, bare soil and grass. Proceedings of the Royal Society of London, Series A,v.193, p.120-145, 1948. 
PEREIRA, A.R. Apontamentos da disciplina LFM 704 - Evapotranspiração. Piracicaba: ESALQ/USP, Depto. de Física e Meteorologia, , SP, 1994, 91p.

PEREIRA, A. R.; ARRUDA, H. V. Ajuste prático de curvas na pesquisa agropecuária. Campinas, Fundação Cargill, 1987. 50p.

PERES, J.G. Avaliação do Modelo de Penman-Monteith, padrão FAO, para estimar a evapotranspiração de referência nas condições climáticas do Estado de São Paulo. Piracicaba, 1994, 116p., Tese de Doutorado - Escola Superior de Agriculura "Luiz de Queiroz"/Universidade de São Paulo.

PRUITT, W. O. ; ANGUS, D. E. Large weighing lysimeter for measuring evapotranspiration. Transactions of the ASAE, n.2, p.13-5, 18, 1960.

RITCHIE, J. T. ; BURNETT, E. A precision weighing lysimeter for row crop water use studies. Agronomy Journal, v.60, p. 545-549.1968.

ROBLEDO , F. Laminas de polietileno y copolimero EVA para usos en agricultura. Hojas Divulgadoras, n. 2, p.1-20, 1987.

ROBLEDO, F. ; VICENTE, L.M. Aplicacion de los plasticos en la agricultura Madrid: Mundi-Prensa, 1988, 573p.

ROSENBERG, N.J.; Mc KENNEY, M.S. ; MARTIN, P. Evapotranspiration in a greenhouse-warmed world: a review and a simulation. Agricultural and Forest Meteorology, v.47, p. 303-20, 1989. 
SCALOPPI, E. J. Exigências de energia para irrigação. ITEM - Irrigação e Tecnologia Moderna, n. 21, p. 13-17, 1985.

SEDIYAMA, G.C. Necessidade de água para os cultivos. Brasília: ABEAS. 1987. 143p. (Curso de Engenharia de Irrigação - módulo 4)

SILVA, A.A.G. da Avaliação da eficiência de métodos de estimativa da evapotranspiração de referência para o município de Pamaíba - PI. Piracicaba: 1989, 80p. Dissertação de Mestrado - Escola Superior de Agricultura "Luiz de Queiroz/Universidade de São Paulo.

SMITH, M. Report on the expert consultation on procedures for revision of FAO guidelines for predictions of crop water requirements. Rome: FAO, 1991, 45p.

STEGMAN, E. C.; MUSICK, J. T. ; STEWART, J. I. Irrigation water management: design and operation of farm irrigation systems. s. 1. ASAE, The American Society of Agricultural Engineering, p. 763-816, 1983.

TANNER, C. B. Measurement of evapotranspiration. In: Irrigation of agricultural lands. Agron. Monograph , v.11, p. 534-545, 1967.

VILLA NOVA, N.A. Principais métodos climáticos de estimativa de aplicação de água de irrigação. Piracicaba. ESALQ/Depto. de Física e Meteorologia, 1987, 22p.

VILLA NOVA, N.A. ; OMETTO, J.C. Adaptação e simplificação do método de Penman às condições climáticas do Estado de São Paulo. In: Simpósio Brasileiro de Hidrologia e Recursos Hídricos, 4,, Fortaleza, 1981. 
VAN BAVEL, C. H. M. Lysimetrc measurements of evapotranspiration in the Eastern United States. Soil Science Society of American Proceedings, v. 25, p. 138-41, 1961.

WILLMOTT, C. J. Some comments on the evaluation of model performance. American Meteorological Society, vol.63, n.11, p.1309-1313, 1982. 
APÊNDICE 
Tabela 14 - Comparação UR interna X UR externa

\begin{tabular}{|c|c|c|c|c|c|c|c|}
\hline dia & $\begin{array}{c}\text { UR } \\
\text { méd.int. }\end{array}$ & UR méd.ext. & Diferença & dia & $\begin{array}{c}\text { UR } \\
\text { méd.int. }\end{array}$ & UR méd.ext. & Diferença \\
\hline & $\%$ & $\%$ & $\%$ & & $\%$ & $\%$ & $\%$ \\
\hline $15 /$ set & 72,91 & 66,10 & 6,81 & 27/out & 55,83 & 46,96 & 8,87 \\
\hline $16 /$ set & 65,87 & 51,91 & 13,96 & $28 /$ out & 82,47 & 88,46 & $-5,98$ \\
\hline $17 /$ set & 85,37 & 82,58 & 2,80 & 29/out & 76,88 & 81,11 & $-4,23$ \\
\hline $18 /$ set & 71,21 & 69,62 & 1,59 & $30 /$ out & 81,00 & 83,28 & $-2,28$ \\
\hline $19 / \mathrm{set}$ & 75,47 & 78,43 & $-2,96$ & 31/out & 78,46 & 82,14 & $-3,67$ \\
\hline $20 /$ set & 85,52 & 81,72 & 3,80 & $01 /$ nov & 78,88 & 81,42 & $-2,55$ \\
\hline $21 / \mathrm{set}$ & 80,93 & 79,25 & 1,69 & $02 /$ nov & 75,79 & 82,45 & $-6,66$ \\
\hline $22 /$ set & 72,27 & 67,98 & 4,29 & $03 /$ nov & 71,75 & 78,66 & $-6,91$ \\
\hline $23 / \mathrm{set}$ & 78,44 & 72,75 & 5,69 & $04 /$ nov & 78,70 & 79,81 & $-1,12$ \\
\hline $24 / \mathrm{set}$ & 84,96 & 90,22 & $-5,26$ & $05 /$ nov & 69,16 & 67,17 & 1,99 \\
\hline $25 /$ set & 75,88 & 76,60 & $-0,71$ & $06 /$ nov & 65,14 & 64,61 & 0,53 \\
\hline $26 /$ set & 78,65 & 79,62 & $-0,98$ & $07 /$ nov & 59,97 & 60,18 & $-0,21$ \\
\hline $27 /$ set & 78,39 & 78,44 & $-0,06$ & $08 /$ nov & 65,17 & 61,63 & 3,55 \\
\hline $28 /$ set & 85,55 & 90,62 & $-5,07$ & $09 /$ nov & 60,19 & 56,67 & 3,52 \\
\hline $29 /$ set & 79,84 & 85,97 & $-6,14$ & $10 /$ nov & 56,86 & 54,55 & 2,31 \\
\hline $30 /$ set & 75,44 & 76,83 & $-1,40$ & $11 / \mathrm{nov}$ & 78,21 & 84,27 & $-6,06$ \\
\hline 01/out & 75,56 & 78,02 & $-2,46$ & $12 /$ nov & 84,94 & 95,12 & $-10,19$ \\
\hline $02 /$ out & 73,99 & 70,09 & 3,90 & $13 /$ nov & 82,39 & 91,23 & $-8,84$ \\
\hline 03/out & 70,51 & 68,90 & 1,61 & $14 /$ nov & 85,58 & 96,73 & $-11,15$ \\
\hline $04 /$ out & 70,62 & 67,79 & 2,83 & $15 /$ nov & 80,93 & 91,58 & $-10,65$ \\
\hline $05 /$ out & 64,46 & 60,07 & 4,39 & $16 / \mathrm{nov}$ & 74,91 & 76,50 & $-1,59$ \\
\hline $06 /$ out & 81,33 & 82,66 & $-1,33$ & $17 /$ nov & 69,51 & 71,34 & $-1,83$ \\
\hline $07 /$ out & 74,21 & 75,62 & $-1,41$ & $18 /$ nov & 78,71 & 82,60 & $-3,89$ \\
\hline $08 /$ out & 71,16 & 66,96 & 4,19 & $19 /$ nov & 74,33 & 73,19 & 1,14 \\
\hline 09/out & 75,72 & 74,73 & 1,00 & $20 /$ nov & 70,93 & 70,65 & 0,27 \\
\hline 10/out & 72,38 & 65,80 & 6,58 & $21 /$ nov & 68,82 & 66,42 & 2,40 \\
\hline 11/out & 69,09 & 63,07 & 6,03 & $22 /$ nov & 71,89 & 67,83 & 4,06 \\
\hline 12/out & 61,38 & 57,94 & 3,44 & $23 /$ nov & 80,28 & 85,83 & $-5,55$ \\
\hline 13/out & 78,67 & 83,78 & $-5,12$ & $24 /$ nov & 80,98 & 89,80 & $-8,82$ \\
\hline 14/out & 89,28 & 97,45 & $-8,17$ & $25 /$ nov & 77,22 & 83,41 & $-6,19$ \\
\hline 15/out & 90,51 & 104,68 & $-14,17$ & $26 /$ nov & 69,79 & 70,09 & $-0 ; 30$ \\
\hline 16/out & 92,60 & 106,14 & $-13,54$ & $27 /$ nov & 66,98 & 68,61 & $-1,63$ \\
\hline 17/out & 93,11 & 107,04 & $-13,93$ & $28 /$ nov & 80,18 & 87,71 & $-7,53$ \\
\hline 18/out & 80,11 & 85,32 & $-5,21$ & $29 /$ nov & 74,95 & 68,85 & 6,10 \\
\hline 19/out & 79,74 & 83,18 & $-3,44$ & $30 /$ nov & 69,03 & 66,72 & 2,31 \\
\hline 20/out & 85,43 & 95,68 & $-10,25$ & $01 / \mathrm{dez}$ & 68,14 & 66,30 & 1,84 \\
\hline 21/out & 84,50 & 92,77 & $-8,26$ & $02 / \mathrm{dez}$ & 67,33 & 53,94 & 13,39 \\
\hline 22/out & 75,01 & 74,86 & 0,15 & $03 / \mathrm{dez}$ & 61,33 & 53,24 & 8,09 \\
\hline 23/out & 70,25 & 68,04 & 2,21 & $04 / \mathrm{dez}$ & 72,90 & 73,47 & $-0,57$ \\
\hline 24/out & 65,11 & 61,25 & 3,86 & $05 / \mathrm{dez}$ & 70,49 & 72,33 & $-1,85$ \\
\hline $25 /$ out & 68,13 & 52,51 & 15,62 & média & 70,49 & 76,65 & $-0,01$ \\
\hline 26/out & 59,30 & 46,34 & 12,96 & & & & \\
\hline
\end{tabular}


Tabela 15 - Obtenção do coeficiente de cultura $(\mathrm{Kc})$ a partir dos valores de índice de área foliar (IAF)

\begin{tabular}{|c|c|c|c|c|c|c|c|}
\hline DATA & dap & IAF & Kc (IAF) & DATA & dap & IAF & Kc (IAF) \\
\hline $15 /$ set & 7 & 0,47 & 0,10 & 26/out & 48 & 3,24 & 0,72 \\
\hline $16 /$ set & 8 & 0,54 & 0,12 & 27 /out & 49 & 3,31 & 0,73 \\
\hline $17 /$ set & 9 & 0,61 & 0,13 & 28/out & 50 & 3,38 & 0,75 \\
\hline $18 /$ set & 10 & 0,68 & 0,15 & 29/out & 51 & 3,44 & 0,76 \\
\hline 19/set & 11 & 0,74 & 0,16 & $30 /$ out & 52 & 3,51 & 0,78 \\
\hline 20/set & 12 & 0,81 & 0,18 & 31/out & 53 & 3,58 & 0,79 \\
\hline $21 /$ set & 13 & 0,88 & 0,19 & $01 /$ nov & 54 & 3,65 & 0,81 \\
\hline $22 /$ set & 14 & 0,95 & 0,21 & $02 /$ nov & 55 & 3,71 & 0,82 \\
\hline $23 /$ set & 15 & 1,01 & 0,22 & $03 /$ nov & 56 & 3,78 & 0,84 \\
\hline $24 /$ set & 16 & 1,08 & 0,24 & $04 /$ nov & 57 & 3,85 & 0,85 \\
\hline $25 /$ set & 17 & 1,15 & 0,25 & $05 /$ nov & 58 & 3,92 & 0,87 \\
\hline $26 /$ set & 18 & 1,22 & 0,27 & $06 /$ nov & 59 & 3,98 & 0,88 \\
\hline $27 /$ set & 19 & 1,28 & 0,28 & 07 Inov & 60 & 4,05 & 0,90 \\
\hline $28 /$ set & 20 & 1,35 & 0,30 & $08 /$ nov & 61 & 4,12 & 0,91 \\
\hline $29 /$ set & 21 & 1,42 & 0,31 & $09 /$ nov & 62 & 4,19 & 0,93 \\
\hline $30 /$ set & 22 & 1,49 & 0,33 & 10/nov & 63 & 4,25 & 0,94 \\
\hline 01/out & 23 & 1,55 & 0,34 & $11 /$ nov & 64 & 4,32 & 0,96 \\
\hline 02/out & 24 & 1,62 & 0,36 & $12 /$ nov & 65 & 4,39 & 0,97 \\
\hline 03/out & 25 & 1,69 & 0,37 & $13 /$ nov & 66 & 4,46 & 0,99 \\
\hline 04/out & 26 & 1,76 & 0,39 & 14/nov & 67 & 4,52 & 1,00 \\
\hline 05/out & 27 & 1,82 & 0,40 & $15 /$ nov & 68 & 4,59 & 1,02 \\
\hline 06/out & 28 & 1,89 & 0,42 & $16 /$ nov & 69 & 4,66 & 1,03 \\
\hline 07 /out & 29 & 1,96 & 0,43 & 17/nov & 70 & 4,73 & 1,05 \\
\hline 08/out & 30 & 2,03 & 0,45 & $18 /$ nov & 71 & 4,79 & 1,06 \\
\hline 09/out & 31 & 2,09 & 0,46 & $19 /$ nov & 72 & 4,86 & 1,08 \\
\hline 10/out & 32 & 2,16 & 0,48 & $20 /$ nov & 73 & 4,93 & 1,09 \\
\hline 11/out & 33 & 2,23 & 0,49 & $21 /$ nov & 74 & 5,00 & 1,11 \\
\hline 12/out & 34 & 2,30 & 0,51 & $22 / n o v$ & 75 & 5,06 & 1,12 \\
\hline 13/out & 35 & 2,36 & 0,52 & $23 /$ nov & 76 & 5,13 & 1,14 \\
\hline 14/out & 36 & 2,43 & 0,54 & $24 /$ nov & 77 & 5,20 & 1,15 \\
\hline 15/out & 37 & 2,50 & 0,55 & $25 /$ nov & 78 & 5,27 & 1,17 \\
\hline 16/out & 38 & 2,57 & 0,57 & $26 /$ nov & 79 & 5,33 & 1,18 \\
\hline 17/out & 39 & 2,63 & 0,58 & 27 Inov & 80 & 5,40 & 1,20 \\
\hline 18/out & 40 & 2,70 & 0,60 & $28 /$ nov & 81 & 5,47 & 1,21 \\
\hline 19/out & 41 & 2,77 & 0,61 & $29 /$ nov & 82 & 5,54 & 1,23 \\
\hline 20/out & 42 & 2,84 & 0,63 & $30 /$ nov & 83 & 5,60 & 1,24 \\
\hline $21 /$ out & 43 & 2,90 & 0,64 & $01 / \mathrm{dez}$ & 84 & 5,67 & 1,26 \\
\hline 22/out & 44 & 2,97 & 0,66 & $02 / \mathrm{dez}$ & 85 & 5,74 & 1,27 \\
\hline 23/out & 45 & 3,04 & 0,67 & $03 / \mathrm{dez}$ & 86 & 5,81 & 1,29 \\
\hline 24/out & 46 & 3,11 & 0,69 & 04/dez & 87 & 5,87 & 1,30 \\
\hline $25 /$ out & 47 & 3,17 & 0,70 & & & & \\
\hline
\end{tabular}


Tabela 17 - Valores estimados de evapotranspiração da cultura (ETc)

\begin{tabular}{|c|c|c|c|c|}
\hline ETc(camargo) & ETc(makkink) & ETc(radiação) & ETc(jensen-haise) & ETc(linacre) \\
\hline & $\mathrm{mm} / \mathrm{dia}$ & $\mathrm{mm} / \mathrm{dia}$ & $\mathrm{mm} / \mathrm{dia}$ & $\mathrm{mm} / \mathrm{dia}$ \\
\hline 0,41 & 0,24 & 0,40 & 0,40 & 0,59 \\
\hline 0,38 & 0,13 & 0,19 & 0,20 & 0,41 \\
\hline 0,54 & 0,25 & 0,39 & 0,40 & 0,69 \\
\hline 0,47 & 0,27 & 0,43 & 0,37 & 0,55 \\
\hline 0,65 & 0,46 & 0,75 & 0,71 & 0,86 \\
\hline 0,67 & 0,29 & 0,45 & 0,45 & 0,82 \\
\hline 0,72 & 0,23 & 0,36 & 0,37 & 0,79 \\
\hline 0,83 & 0,57 & 0,91 & 0,89 & 1,05 \\
\hline 0,84 & 0,41 & 0,66 & 0,65 & 1,02 \\
\hline 0,97 & 0,42 & 0,67 & 0,67 & 1,15 \\
\hline 1,14 & 0,83 & 1,34 & 1,34 & 1,47 \\
\hline 1,37 & 0,77 & 1,24 & 1,25 & 1,54 \\
\hline 1,46 & 0,91 & 1,47 & 1,49 & 1,68 \\
\hline 1,55 & 1,06 & 1,74 & 1,72 & 1,86 \\
\hline 1,46 & 0,34 & 0,52 & 0,56 & 1,49 \\
\hline 1,70 & 0,82 & 1,31 & 1,34 & 1,94 \\
\hline 1,85 & 0,40 & 0,62 & 0,71 & 2,22 \\
\hline 1,81 & 0,92 & 1,49 & 1,48 & 2,11 \\
\hline 1,77 & 1,09 & 1,78 & 1,69 & 2,15 \\
\hline 1,92 & 1,07 & 1,76 & 1,71 & 2,60 \\
\hline 1,94 & 0,38 & 0,58 & 0,66 & 2,07 \\
\hline 1,87 & 0,34 & 0,49 & 0,58 & 1,71 \\
\hline 1,94 & 0,15 & 0,18 & 0,31 & 1,74 \\
\hline 1,68 & 0,07 & 0,06 & 0,19 & 1,42 \\
\hline 2,19 & 1,51 & 2,44 & 2,34 & 2,29 \\
\hline 2,27 & 1,20 & 1,92 & 1,90 & 2,40 \\
\hline 2,05 & 0,76 & 1,18 & 1,16 & 1,97 \\
\hline 2,08 & 0,61 & 0,93 & 0,94 & 2,02 \\
\hline 2,16 & 1,85 & 3,01 & 2,69 & 2,42 \\
\hline 2,24 & 2,00 & 3,28 & 2,93 & 2,69 \\
\hline 2,56 & 2,01 & 3,31 & 3,12 & 3,29 \\
\hline 2,82 & 2,06 & 3,38 & 3,34 & 3,50 \\
\hline 2,99 & 2,04 & 3,38 & 3,38 & 4,18 \\
\hline 3,12 & 1,76 & 2,92 & 2,98 & 4,57 \\
\hline 2,71 & 0,32 & 0,45 & 0,60 & 2,74 \\
\hline 2,36 & 0,35 & 0,51 & 0,60 & 2,57 \\
\hline 2,42 & 0,81 & 1,26 & 1,22 & 2,57 \\
\hline 2,92 & 1,51 & 2,42 & 2,28 & 2,88 \\
\hline 3,14 & 2,25 & 3,65 & 3,41 & 3,24 \\
\hline 3,34 & 2,24 & 3,65 & 3,48 & 3,65 \\
\hline 3,31 & 1,16 & 1,83 & 1,86 & 3,28 \\
\hline 3,70 & 2,13 & 3,48 & 3,46 & 4,20 \\
\hline 3,97 & 2,86 & 4,72 & 4,74 & 4,79 \\
\hline
\end{tabular}


Continuação da Tabela 17

\begin{tabular}{|c|c|c|c|c|}
\hline 4,32 & 3,04 & 5,06 & 5,22 & 5,61 \\
\hline 4,55 & 3,16 & 5,23 & 5,54 & 5,59 \\
\hline 4,47 & 3,04 & 5,05 & 5,23 & 5,79 \\
\hline 4,56 & 2,53 & 4,20 & 4,40 & 6,17 \\
\hline 4,29 & 1,85 & 2,97 & 3,13 & 4,38 \\
\hline 3,81 & 1,12 & 1,74 & 1,81 & 3,59 \\
\hline 4,20 & 1,65 & 2,61 & 2,69 & 4,07 \\
\hline 4,46 & 3,04 & 4,95 & 4,94 & 4,71 \\
\hline 4,69 & 3,49 & 5,74 & 5,76 & 5,34 \\
\hline 4,41 & 2,01 & 3,22 & 3,26 & 4,40 \\
\hline 3,54 & 2,93 & 4,78 & 4,36 & 3,72 \\
\hline 3,58 & 3,21 & 5,26 & 4,74 & 3,94 \\
\hline 3,79 & 3,61 & 5,95 & 5,45 & 4,30 \\
\hline 4,13 & 3,62 & 5,94 & 5,68 & 4,52 \\
\hline 3,98 & 2,36 & 3,79 & 3,67 & 3,86 \\
\hline 4,61 & 3,75 & 6,11 & 6,12 & 4,75 \\
\hline 4,95 & 3,99 & 6,57 & 6,72 & 5,66 \\
\hline 5,18 & 4,08 & 6,73 & 6,79 & 5,89 \\
\hline 5,43 & 4,11 & 6,78 & 6,97 & 6,28 \\
\hline 5,13 & 2,75 & 4,46 & 4,52 & 5,45 \\
\hline
\end{tabular}

Tabela 18 - Continuação dos valores estimados da evapotranspiração da cultura

\begin{tabular}{|c|c|c|c|c|}
\hline $\begin{array}{c}\text { ETc(harg- } \\
\text { samani) }\end{array}$ & ETc(pen-simp) & ETtanque & ETc(pen) & ETc(pen-m) \\
\hline mm/dia & $\mathbf{m m} /$ dia & $\mathbf{m m} / \mathbf{d i a}$ & $\mathbf{m m} / \mathbf{d i a}$ & $\mathbf{m m / d i a}$ \\
\hline 0,22 & 0,49 & 0,29 & 0,06 & 0,14 \\
\hline 0,11 & 0,31 & 0,13 & 0,01 & 0,04 \\
\hline 0,26 & 0,44 & 0,32 & 0,08 & 0,14 \\
\hline 0,05 & 0,59 & 0,49 & 0,02 & 0,28 \\
\hline 0,15 & 1,01 & 0,25 & 0,04 & 0,25 \\
\hline 0,49 & 0,58 & 0,21 & 0,10 & 0,12 \\
\hline 0,27 & 0,51 & 0,14 & 0,04 & 0,07 \\
\hline 0,21 & 1,18 & 0,01 & 0,00 & 0,02 \\
\hline 0,52 & 0,95 & 0,08 & 0,04 & 0,08 \\
\hline 0,47 & 0,98 & 0,66 & 0,31 & 0,65 \\
\hline 0,18 & 1,62 & 1,05 & 0,19 & 1,69 \\
\hline 0,06 & 1,55 & 1,46 & 0,09 & 2,27 \\
\hline 0,43 & 1,88 & 1,20 & 0,52 & 2,26 \\
\hline 0,93 & 2,29 & 0,46 & 0,43 & 1,06 \\
\hline 0,87 & 0,88 & 0,78 & 0,68 & 0,68 \\
\hline 1,07 & 1,84 & 1,07 & 1,14 & 1,97 \\
\hline 1,14 & 1,10 & 1,25 & 1,43 & 1,37 \\
\hline 1,37 & 2,05 & 1,25 & 1,71 & 2,56 \\
\hline 0,72 & 2,36 & 1,04 & 0,75 & 2,46 \\
\hline 0,28 & 2,54 & 0,36 & 0,10 & 0,91 \\
\hline & & & & \\
\hline
\end{tabular}




\begin{tabular}{|c|c|c|c|c|}
\hline \multicolumn{5}{|c|}{ Continuação da Tabela 18} \\
\hline 0,96 & 0,88 & 0,19 & 0,18 & 0,17 \\
\hline 0,48 & 0,78 & 0,49 & 0,23 & 0,38 \\
\hline 0,56 & 0,41 & 0,23 & 0,13 & 0,09 \\
\hline 1,02 & 0,27 & 1,30 & 1,32 & 0,35 \\
\hline 1,30 & 2,97 & 1,24 & 1,62 & 3,69 \\
\hline 1,38 & 2,48 & 0,96 & 1,33 & 2,39 \\
\hline 0,38 & 1,60 & 0,49 & 0,18 & 0,78 \\
\hline 0,24 & 1,33 & 2,02 & 0,48 & 2,69 \\
\hline 0,13 & 3,75 & 0,32 & 0,04 & 1,20 \\
\hline 0,09 & 4,09 & 0,31 & 0,03 & 1,26 \\
\hline 0,08 & 4,19 & 2,09 & 0,16 & 8,76 \\
\hline 1,74 & 4,34 & 1,62 & 2,81 & 7,03 \\
\hline 1,25 & 4,50 & 1,89 & 2,37 & 8,52 \\
\hline 0,81 & 3,78 & 0,80 & 0,65 & 3,04 \\
\hline 0,51 & 1,01 & 0,16 & 0,08 & 0,16 \\
\hline 1,87 & 1,03 & 0,81 & 1,52 & 0,83 \\
\hline 2,21 & 1,84 & 1,05 & 2,31 & 1,93 \\
\hline 2,39 & 3,23 & 1,74 & 4,16 & 5,60 \\
\hline 2,52 & 4,58 & 1,03 & 2,60 & 4,71 \\
\hline 2,43 & 4,72 & 0,89 & 2,16 & 4,19 \\
\hline 2,07 & 2,67 & 1,20 & 2,50 & 3,21 \\
\hline 0,32 & 4,59 & 2,82 & 0,91 & 12,93 \\
\hline 0,30 & 4,86 & 2,11 & 0,63 & 10,26 \\
\hline 0,01 & 6,69 & 2,94 & 0,03 & 19,66 \\
\hline 0,73 & 6,89 & 1,57 & 1,15 & 10,82 \\
\hline 1,69 & 6,48 & 1,78 & 3,01 & 11,55 \\
\hline 2,42 & 5,72 & 0,95 & 2,31 & 5,46 \\
\hline 2,37 & 3,92 & 1,20 & 2,85 & 4,72 \\
\hline 2,46 & 2,41 & 2,23 & 5,48 & 5,38 \\
\hline 3,63 & 2,90 & 4,18 & 15,18 & 12,13 \\
\hline 3,65 & 5,77 & 1,92 & 7,03 & 11,11 \\
\hline 3,23 & 6,73 & 1,31 & 4,24 & 8,83 \\
\hline 2,66 & 4,25 & 2,85 & 7,56 & 12,10 \\
\hline 1,65 & - & - & - & - \\
\hline 0,50 & - & - & - & - \\
\hline 0,88 & - & - & - & - \\
\hline 0,77 & - & - & - & - \\
\hline 1,31 & - & - & - & - \\
\hline 3,33 & - & - & - & - \\
\hline 1,93 & - & - & - & - \\
\hline 3,90 & - & - & - & - \\
\hline 4,19 & - & - & - & - \\
\hline 2,22 & - & - & - & - \\
\hline
\end{tabular}

